\title{
Natural Compounds for Alzheimer's Disease Therapy: A Systematic Review of Preclinical and Clinical Studies
}

\author{
Stephanie Andrade, Maria João Ramalho (D), Joana Angélica Loureiro * and \\ Maria do Carmo Pereira * \\ LEPABE, Department of Chemical Engineering, Faculty of Engineering of the University of Porto, \\ 4200-465 Porto, Portugal; stephanie@fe.up.pt (S.A.); mjramalho@fe.up.pt (M.J.R.) \\ * Correspondence: joana.loureiro@fe.up.pt (J.A.L.); mcsp@fe.up.pt (M.d.C.P.)
}

Received: 16 April 2019; Accepted: 7 May 2019; Published: 10 May 2019

check for updates

\begin{abstract}
Alzheimer's Disease (AD) is a neurodegenerative disorder related with the increase of age and it is the main cause of dementia in the world. AD affects cognitive functions, such as memory, with an intensity that leads to several functional losses. The continuous increase of AD incidence demands for an urgent development of effective therapeutic strategies. Despite the extensive research on this disease, only a few drugs able to delay the progression of the disease are currently available. In the last years, several compounds with pharmacological activities isolated from plants, animals and microorganisms, revealed to have beneficial effects for the treatment of $\mathrm{AD}$, targeting different pathological mechanisms. Thus, a wide range of natural compounds may play a relevant role in the prevention of $\mathrm{AD}$ and have proven to be efficient in different preclinical and clinical studies. This work aims to review the natural compounds that until this date were described as having significant benefits for this neurological disease, focusing on studies that present clinical trials.
\end{abstract}

Keywords: neurodegenerative disease; bioactive compound; natural extract; $\beta$-amyloid peptide; tau protein; clinical trial; human studies; animal studies; in vitro studies

\section{Introduction}

Neurodegenerative diseases induce alterations in the central nervous system with psychological and physiological negative effects [1]. Alzheimer's disease (AD) is known as a neurodegenerative disorder with major importance and the principal cause of dementia among the elderly [2,3]. Microscopically, intraneuronal neurofibrillary tangles (NFTs) and extracellular senile plaques (or amyloid plaques) characterize the $\mathrm{AD}$. While senile plaques are constituted by extracellular deposits of $\beta$-amyloid $(\mathrm{A} \beta)$ peptide, the hyperphosphorylation and abnormal deposition of tau protein compose the NFTs [4].

$\mathrm{A} \beta$ derives from the amyloid precursor protein (APP), proteolytic cleavage of amyloid precursor protein (APP), an integral membrane protein that possesses the general properties of a cell surface receptor [5], by the consecutive action of $\beta$ - and $\gamma$-secretases (amyloidogenic pathway). However, this amyloidogenic pathway can be stopped by the competition of $\alpha$-secretase with $\gamma$-secretase (non-amyloidogenic pathway) [6]. The amyloid cascade hypothesis (ACH) suggests that the imbalance between the $\mathrm{A} \beta$ generation and its clearance causes the dysfunction and consequently cell death. $A \beta$ polymerizes in a variety of structurally different forms including oligomeric, protofibrillar, and fibrils, forming the senile plaques [7]. Several findings suggest that oligomers play an important role in the $\mathrm{ACH}$ [8]. Nowadays, it is proved that $\mathrm{A} \beta$ oligomers, including protofibrils and prefibrils, are more toxic than fibrils [9]. Tau protein is also related with the ACH. First, tau monomers aggregate and form oligomers that aggregate into a $\beta$-sheet conformation, forming NFTs [10]. NFTs accumulate 
inside the neurons, resulting in their death. The $\mathrm{ACH}$ suggests that toxic concentrations of $\mathrm{A} \beta$ cause changes in tau protein and subsequent formation of NFTs, leading to synaptic and neuronal loss [11]. Though a direct relationship between the degree of $\mathrm{AD}$ and the amount of $\mathrm{A} \beta$ aggregates and tau levels have been established, numerous other mechanisms of neurodegeneration have been suggested, such as neuroinflammation [12], oxidative stress [13], genetic [14] and environmental factors [15]. So, there is an urgent need to develop efficient therapies that target the various pathogenic mechanisms associated with AD. Based on these mechanisms, different therapeutic molecules can act through different pathways [16-18]. However, the currently available medications only control the symptoms in an early stage of the disease [11].

Therefore, it is fundamental to seek for new strategies for AD therapy [19-22]. Natural compounds were the first molecules used as therapeutic agents [23]. Nowadays, the study of these natural compounds revealed that they present neuroprotective effects, arousing an increasing interest in the scientific community and in the pharmaceutical industry [24,25]. A diversity of natural compounds from different origins was described to be suitable to prevent and attenuate several pathologies, including neurological diseases, such as AD [26-28]. Several in vitro and in vivo studies have proven the therapeutic potential of natural compounds, however, just a small percentage has reached the clinical trials stage [29]. Since several causes are related with this disease, the preventive properties of the natural compounds can be associated with several mechanisms as shown in Figure 1 [6,30-34].

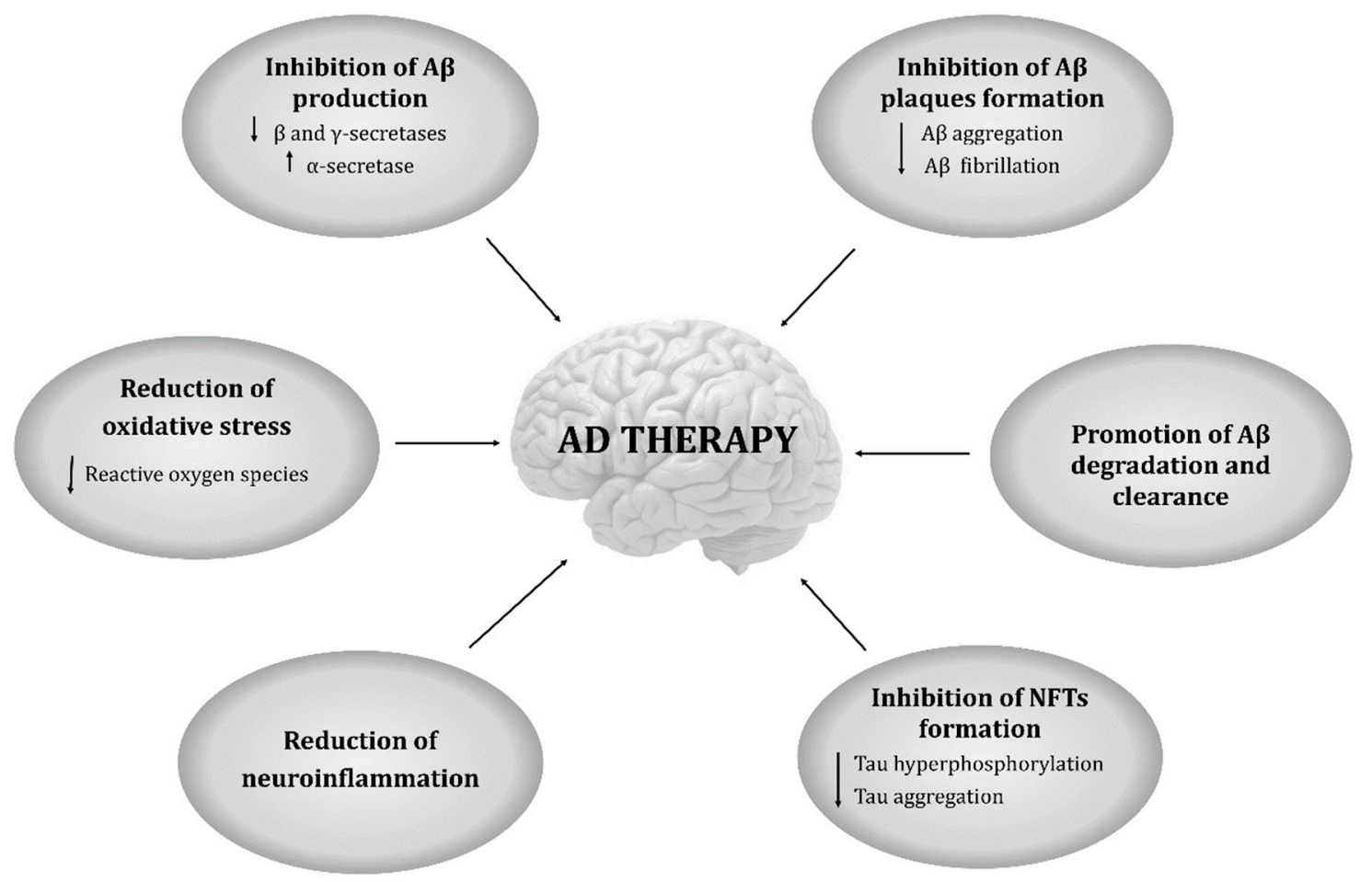

Figure 1. Schematic representation of the several mechanisms associated with Alzheimer's Disease (AD) therapy. Down and up oriented arrows indicate the decrease and the increase of the fenomena, respectively.

In this review, the natural compounds already in clinical trials phase are described and the reported results are presented and discussed. Other natural compounds with known potentially beneficial effects in $\mathrm{AD}$ in a preclinical development stage with in vitro and in vivo studies are also described. For preclinical studies, only the most recent reported works are cited. The systematic literature search was conducted using PubMed, Science direct, Google Scholar, Scopus and Web of Science as online databases until April 2019. Only papers written in English were considered with unlimited publication date. 


\section{Natural Compounds in Clinical Trials and Their Effects on AD}

Natural compounds are an emerging approach for AD therapy. For the assessment of their therapeutic efficiency and potential side effects, human trials have been performed in the last years. The first natural product studied in a clinical trial was nicotine in 1992. However, no clinical trials were performed in the last two decades for this molecule. During the 90s, several other compounds were studied in clinical trials for AD therapy, such as vitamins. These molecules are still being tested in human trials up until this date. In the last years, other natural compounds are gaining interest by the scientific community and have achieved the clinical trials phase, such as bryostatin, which effects started to be evaluated in humans in 2017. A detailed report of these findings is described below. The natural compounds were divided into two groups: bioactive compounds and natural extracts, and they are summarized in Tables 1 and 2, respectively. Here, a bioactive compound refers to a therapeutic molecule while a natural extract is the mixture of several molecules. The compounds are listed from the ones with more participants and longer duration.

Table 1. Bioactive compounds in clinical trials for AD therapy.

\begin{tabular}{|c|c|c|c|c|c|}
\hline Bioactive Compound & Condition of Participants & $\begin{array}{l}\text { Number of } \\
\text { Subjects }\end{array}$ & Duration & Outcomes & Ref. \\
\hline \multirow[b]{2}{*}{ Vitamin D } & Mild cognitive impairment & 8 & 8 weeks & Reduction of $\mathrm{A} \beta$ level & [35] \\
\hline & $\begin{array}{l}\text { Mild cognitive impairment } \\
\text { and early AD }\end{array}$ & 48 & 20 months & $\begin{array}{l}\text { Reduction of } \mathrm{A} \beta \text { level; } \\
\text { Improvement of cognitive functions }\end{array}$ & [36] \\
\hline $\begin{array}{l}\text { Vitamin D and } \\
\text { memantine }\end{array}$ & Moderate AD & 43 & 24 weeks & Improvement of cognitive functions & [37] \\
\hline $\begin{array}{l}\text { Vitamin D and } \\
\text { antioxidants }\end{array}$ & Mild to moderate AD & 78 & 16 weeks & Reduction of oxidative stress & [38] \\
\hline Vitamin $E$ and vitamin $C$ & $\mathrm{AD}$ & 20 & 1 month & Reduction of oxidative stress & [39] \\
\hline Vitamin E and selegiline & Moderate AD & 341 & 2 years & Delay of AD progression & [40] \\
\hline Vitamin E and donepezil & Mild cognitive impairment & 769 & 5 years & $\begin{array}{l}\text { No effectiveness in delaying } \\
\text { AD progression }\end{array}$ & [41] \\
\hline $\begin{array}{l}\text { Vitamin E and } \\
\text { memantine }\end{array}$ & Mild to moderate AD & 613 & 5 years & Delay of AD progression & [42] \\
\hline Vitamin $\mathrm{E}$ and selenium & Healthy patients & 3786 & 13 years & No prevention of dementia & [43] \\
\hline $\begin{array}{l}\text { Docosahexaenoic acid } \\
\text { (DHA) and } \\
\text { eicosapentaenoic acid }\end{array}$ & $\mathrm{AD}$ & 204 & 12 months & $\begin{array}{l}\text { Safe and well tolerated; } \\
\text { No effectiveness in delaying } \\
\text { cognitive decline }\end{array}$ & [44] \\
\hline \multirow{3}{*}{ DHA } & $\mathrm{AD}$ & 295 & 18 months & $\begin{array}{l}\text { No effectiveness in delaying } \\
\text { cognitive decline }\end{array}$ & [45] \\
\hline & Cognitive impairments & 485 & 24 weeks & Improvement of cognitive functions & [46] \\
\hline & Mild cognitive impairment & 36 & 1 year & $\begin{array}{l}\text { Safe and well tolerated; } \\
\text { Improvement of memory }\end{array}$ & [47] \\
\hline \multirow{3}{*}{ Homotaurine } & \multirow{3}{*}{ Mild to moderate AD } & 1052 & 78 weeks & Improvement of cognitive functions & $\begin{array}{l}{[48,} \\
49]\end{array}$ \\
\hline & & 58 & 3 months & $\begin{array}{l}\text { No harmful effects on vital signs; } \\
\text { Side effects }\end{array}$ & [50] \\
\hline & & 10 & 4 weeks & $\begin{array}{l}\text { Improvement of the central } \\
\text { cholinergic transmission }\end{array}$ & [51] \\
\hline \multirow{3}{*}{ Huperzine A } & \multirow[b]{2}{*}{$\mathrm{AD}$} & 103 & 8 weeks & $\begin{array}{l}\text { Safe and well tolerated; Improvement } \\
\text { of memory and behaviour }\end{array}$ & [52] \\
\hline & & 60 & 60 days & $\begin{array}{l}\text { Safe and well tolerated; } \\
\text { Reduction of oxidative stress }\end{array}$ & [53] \\
\hline & Mild to moderate AD & 177 & 16 weeks & $\begin{array}{l}\text { Safe and well tolerated; Improvement } \\
\text { of cognitive functions }\end{array}$ & [54] \\
\hline \multirow[t]{2}{*}{ Bryostatin } & \multirow[t]{2}{*}{$\mathrm{AD}$} & 9 & 46 weeks & $\begin{array}{l}\text { Safe and well tolerated: Improvement } \\
\text { of cognitive functions }\end{array}$ & [55] \\
\hline & & 150 & 12 weeks & Improvement of cognitive functions & [56] \\
\hline \multirow{4}{*}{ Melatonin } & \multirow{2}{*}{$\mathrm{AD}$} & 150 & 12 weeks & Improvement of memory & [57] \\
\hline & & 14 & 22 to 35 months & Improvement of cognitive functions & [58] \\
\hline & Mild cognitive impairment & 50 & 9 to 18 months & Improvement of cognitive functions & [59] \\
\hline & Mild to moderate AD & 80 & 24 weeks & $\begin{array}{l}\text { Safe; Improvement of } \\
\text { cognitive functions }\end{array}$ & [60] \\
\hline
\end{tabular}


Table 1. Cont.

\begin{tabular}{lcccl}
\hline Bioactive Compound & Condition of Participants & $\begin{array}{c}\text { Number of } \\
\text { Subjects }\end{array}$ & Duration & Outcomes \\
\hline Resveratrol & Mild to moderate AD & 119 & 52 weeks & $\begin{array}{l}\text { Side effects; No effectiveness in } \\
\text { reducing biomarkers levels }\end{array}$ \\
\cline { 3 - 5 } & & 39 & 1 year & $\begin{array}{l}\text { Safe and well tolerated; } \\
\text { No effectiveness in treat AD }\end{array}$ \\
\hline [61] & 70 & 2 weeks & $\begin{array}{l}\text { Improvement of perceptual and } \\
\text { visual attentional deficits }\end{array} \quad$ [62] \\
\cline { 2 - 5 } & AD & 6 & 9 weeks & Safe; Improvement of learning \\
\hline Curcumin & AD & 8 & 10 weeks & $\begin{array}{l}\text { Improvement of } \\
\text { attentional performance }\end{array}$ \\
\hline
\end{tabular}

Table 2. Natural extracts and other natural products in clinical trials for AD therapy.

\begin{tabular}{|c|c|c|c|c|c|}
\hline $\begin{array}{l}\text { Natural Extracts and } \\
\text { Other Products }\end{array}$ & Condition of Participants & $\begin{array}{l}\text { Number of } \\
\text { Subjects }\end{array}$ & Duration & Outcomes & Ref. \\
\hline \multirow{3}{*}{ Ginkgo biloba } & $\begin{array}{l}\text { Mild to moderate } \\
\text { dementia }\end{array}$ & 410 & 24 weeks & $\begin{array}{l}\text { Safe; Improvement of } \\
\text { neuropsychiatric symptoms }\end{array}$ & $\begin{array}{l}{[67,} \\
68]\end{array}$ \\
\hline & $\mathrm{AD}$ or vascular dementia & 404 & 24 weeks & $\begin{array}{l}\text { Improvement of cognitive functions and } \\
\text { functional abilities; Improvement of } \\
\text { neuropsychiatric symptoms }\end{array}$ & [70] \\
\hline & Mild cognitive impairment & 160 & 24 weeks & $\begin{array}{l}\text { Safe and well tolerated; Improvement of } \\
\text { cognitive functions }\end{array}$ & [71] \\
\hline Saffron & Mild to moderate AD & 46 & 16 weeks & $\begin{array}{l}\text { Safe; Improvement of cognitive functions } \\
\text { and memory }\end{array}$ & [72] \\
\hline Lemon balm & Mild to moderate AD & 40 & 4 months & $\begin{array}{l}\text { Improvement of cognition function } \\
\text { and agitation }\end{array}$ & [73] \\
\hline Coconut & $\mathrm{AD}$ & 44 & 21 days & Improvement of cognitive functions & [77] \\
\hline Apple & Moderate to severe $\mathrm{AD}$ & 21 & 1 month & $\begin{array}{l}\text { No improvement of cognitive functions; } \\
\text { Improvement behavioural and psychotic } \\
\text { symptoms; Reduction of anxiety, agitation } \\
\text { and delusion }\end{array}$ & [78] \\
\hline Blueberry & Early memory failures & 9 & 12 weeks & $\begin{array}{l}\text { Improvement of learning; Reduction of } \\
\text { depressive symptoms }\end{array}$ & [79] \\
\hline Colostrinin & $\mathrm{AD}$ & n. d. & 15 weeks & $\begin{array}{l}\text { Improvement of cognitive and } \\
\text { daily functions }\end{array}$ & [80] \\
\hline
\end{tabular}

n. d.-The information was not provided by the authors.

\subsection{Bioactive Compounds}

Vitamins have been described as therapeutic compounds for AD. Among them, vitamin C, E and D have aroused great interest. Vitamin C (Figure 2A) is found in several vegetables and fruits, mostly citrus fruits. In vivo studies reported that vitamin $C$ prevented the neuroinflammation [81] and the brain oxidative damage due to its potent antioxidant activity [82]. Also, it was observed in an $\mathrm{AD}$ mouse model that Vitamin $\mathrm{C}$ reduced the $\mathrm{A} \beta$ oligomers formation and tau phosphorylation, improving the behavioral decline. The reduction of $A \beta$ levels [83] and $A \beta$ plaque burden [84] was also observed in vivo.

On the other hand, vitamin E, which is present in several fruits and vegetables (Figure 2B), also showed in vivo antioxidant and anti-inflammatory effects [85]. Other in vivo study revealed that vitamin $E$ reduced the $A \beta$ levels [86].

Other vitamin with reported beneficial effects for $A D$, is vitamin $D$. Adding to several benefits of vitamin D [87], its therapeutic effect in AD has also been studied in last years. Although the major source of vitamin D is sunlight exposure (vitamin $\mathrm{D}_{3}$, Figure 2 C) [88], around $20 \%$ can be obtained 
from food, including fatty fish and fish-liver oils (vitamin $\mathrm{D}_{2}$, Figure 2D) [89]. In vivo studies revealed that vitamin $D$ is an anti-inflammatory compound [90] with the ability to inhibit the activity of $\beta$ and $\gamma$-secretases, reducing the $A \beta$ production and amyloid plaques and to increase the $A \beta$ degradation [91]. As result, an improvement on learning and memory performance was verified in AD rats [92,93]. Also, low plasma $A \beta$ is linked to the incidence of $A D$.<smiles>O=C1O[C@H](C(O)CO)C(O)=C1O</smiles>

(b)

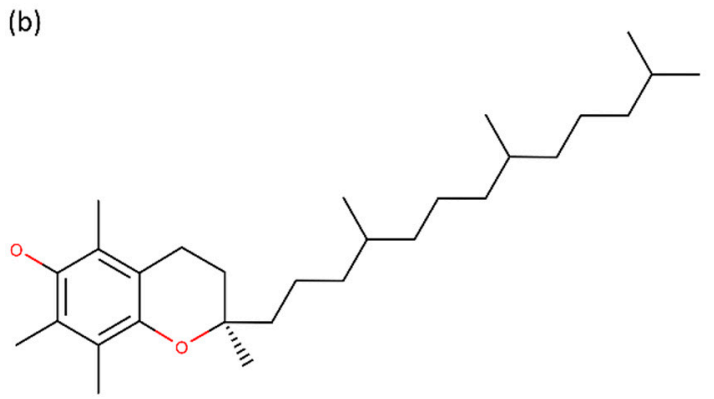

(c)

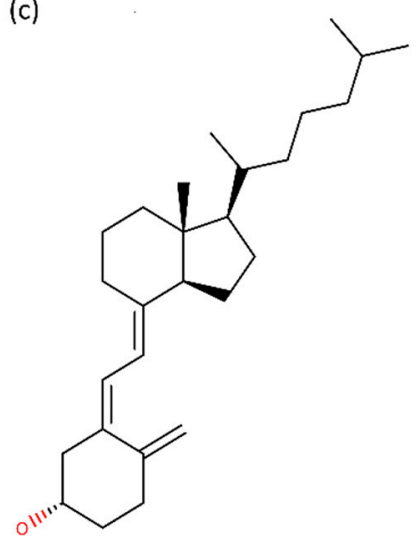

(d)

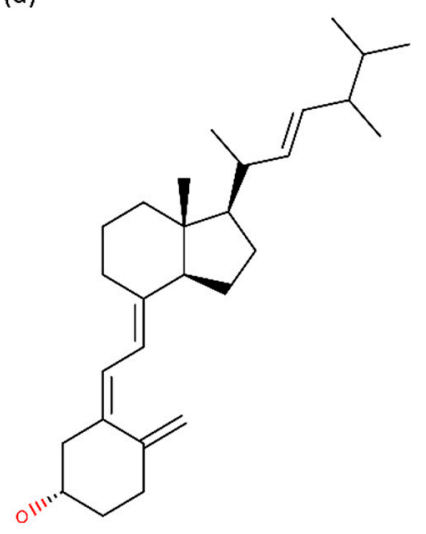

Figure 2. Chemical structures of: (a) vitamin $C$, (b) vitamin $E$, (c) vitamin $D_{3}$ and (d) vitamin $D_{2}$.

Clinical trials revealed that vitamin $D$ increased plasma $A \beta$ in mild cognitive impairment patients, suggesting a reduction in $A \beta$ levels in the brain. In fact, Miller et al. (2016) studied the effect of vitamin D supplementation on the plasma levels of $A \beta$ in eight patients over 60 years old in a pilot study. Patients were randomly divided in two groups, treatment and placebo groups. Patients from the treatment group were administered with 50,000 IU per week for eight weeks. The obtained results showed that vitamin $D$ intake increased plasma $A \beta$ levels, suggesting a decrease in $A \beta$ brain levels [35].

SanMartin et al. (2017) evaluated the role of vitamin D in the $A \beta$ clearance from the brain. Patients with mild cognitive impairment and very early $\operatorname{AD}(n=47)$ were orally supplemented with vitamin D at 50,000 IU once a week for six weeks, followed by 1500-2000 IU daily for 18 months. The obtained results showed that lymphocyte susceptibility to death, $A \beta$ plasma levels and cognitive status improved after six months of vitamin D supplementation in cognitive impairment patients, but not in very early $\mathrm{AD}$ patients. Thus, supplementation with vitamin $\mathrm{D}$ proved to be beneficial in cognitive impairment patients. The lack of effects in very early $A D$ patients suggest that vitamin $D$ intake is not able to delay the progression of the disease in a more advanced stage [36].

Co-therapy with vitamin $\mathrm{D}$ and other molecules for AD therapy has also been explored in clinical trials. In fact, Annweiler et al. (2012) conducted a double-blind, placebo-controlled pilot trial with 43 white patients over 60 years with moderate AD symptoms [37]. The main goal of this trial was to evaluate the combination of neuroprotective effects of memantine and vitamin D in preventing neuronal loss and cognitive decline. Memantine was selected because is one of the most prescribed drugs for AD therapy [94]. Patients were randomly divided in three groups, being administered with memantine plus vitamin $\mathrm{D}(n=8)$, or memantine alone $(n=18)$, or vitamin $\mathrm{D}$ alone $(n=17)$. Patients 
were administered with drugs for 24 weeks. Memantine was administered orally at $5 \mathrm{mg}$ per week for the first four weeks and then $20 \mathrm{mg}$ per day for the rest of the trial. Patients received a drinking solution of vitamin D at 100,000 IU every four weeks. After the study, patients co-treated with memantine and vitamin $\mathrm{D}$ showed better cognitive performance than patients treated with vitamin $\mathrm{D}$ or memantine alone [37].

Co-supplementation with vitamin $\mathrm{D}$ and other natural compounds was also studied in clinical trials. In fact, Galasko et al. (2012) conducted a double-blind, placebo-controlled clinical trial to evaluate what antioxidant supplementation affected the levels of AD's histopathological marks, such as $\mathrm{A} \beta$ peptide and tau protein [38]. Patients with mild to moderate $\operatorname{AD}(n=78)$ received placebo or daily supplement containing $800 \mathrm{IU}$ of vitamin E, $500 \mathrm{mg}$ of vitamin D, $900 \mathrm{mg}$ of $\alpha$-lipoic acid and $400 \mathrm{mg}$ of coenzyme $\mathrm{Q}$ for 16 weeks. The attained results showed that the co-supplementation did not affect amyloid or tau levels, but a reduction on levels of an oxidative stress biomarker, the cerebrospinal fluid F2-isoprostane, was verified.

Also, co-supplementation with multivitamins was evaluated in clinical trials. In fact, Kontush et al. (2001) evaluated the efficiency of supplementation with both vitamin $E$ and vitamin $C$ to decrease oxidation of lipoproteins in AD patients [39]. Lipid oxidation is related with AD progression. Twenty patients with $\mathrm{AD}$ were randomly divided in two groups. The first group received a daily supplement for one month of $400 \mathrm{IU}$ vitamin $\mathrm{E}$ alone, and the second group received a daily combination of $400 \mathrm{IU}$ vitamin $\mathrm{E}$ and $1000 \mathrm{mg}$ of vitamin $\mathrm{C}$. The obtained results proved that combined supplementation was more efficient in maintaining active doses of vitamins in the plasma and decreasing lipid oxidation.

Co-therapy of different drugs with vitamin E was also studied in clinical trials. Sano et al. (1997) evaluated the effects of vitamin E and selegiline co-administration [40]. Selegiline is a monoamine oxidase inhibitor, that prevents dopamine degradation [95]. For that, a double-blind, placebo-controlled clinical trial was conducted with 341 patients with moderate AD's symptoms for two years. The patients were randomly divided in four groups, a placebo group, one receiving vitamin $\mathrm{E}$, one receiving selegiline, and another one receiving both drugs. Vitamin E was daily administered at a dose of $2000 \mathrm{IU}$ per day, and $10 \mathrm{mg}$ of selegiline daily. Co-therapy proved to efficiently slow the progression of the disease [40].

The combined effect of donepezil and vitamin E was also studied. Donepezil is a drug used for AD therapy to control the symptoms. To compare the effects of this drug with vitamin $\mathrm{E}$ on the outcome effects on patients with mild cognitive impairment, a double-blind, placebo-controlled clinical trial was conducted by Petersen et al. (2005) [41]. Patients over the age of $55(n=769)$ were randomly divided in three groups, placebo, vitamin E alone or donepezil alone. The daily dose of vitamin E was $1000 \mathrm{IU}$, and after six weeks the dose was increased to $2000 \mathrm{IU}$, for five years. Vitamin E proved to not be able to delay the disease progression.

Dysken et al. (2014) studied the combination effects of vitamin E and memantine [42]. For that, a double-blind, placebo-controlled clinical trial was conducted with 613 patients with mild to moderate AD's symptoms for five years. The patients were randomly divided in three groups, one receiving vitamin $\mathrm{E}$, one receiving memantine, and another one receiving both vitamin $\mathrm{E}$ and memantine. The used doses for vitamin E were $2000 \mathrm{IU}$ per day, and $20 \mathrm{mg}$ of memantine daily. Treatment with vitamin $\mathrm{E}$ alone proved to be more efficient in slowing disease cognitive decline comparatively with the placebo group. However, no differences were verified for co-therapy comparatively with treatment with memantine alone.

Kryscio et al. (2017) intended to assess if vitamin E and selenium intake could prevent dementia in healthy men over 60 [43]. Although no evidence exists to support the use of selenium in the treatment of $\mathrm{AD}$, some works suggest that this product has a preventive potential [96]. A double-blind, placebo-controlled clinical trial involving 3786 male patients was conducted for 13 years. The participants were randomly divided into four groups. The first group received vitamin E, to the second only selenium was administered, the third group received a combination of vitamin $\mathrm{E}$ and selenium, and the fourth received placebo. The conclusions of this trials were that neither of the supplementation regimen proved to be able in preventing dementia [43]. 
Docosahexaenoic acid (DHA) is a polyunsaturated fatty acid from marine fish and algae [97] and its structural formula is presented in Figure 3. DHA demonstrated to have an antioxidant activity reducing the lipid peroxide and reactive oxygen species (ROS) levels in the brain of AD rats, improving the learning [98]. In addition, in vivo experiments showed that DHA reduces the A $\beta$ levels, $A \beta$ accumulation and plaque burden [99]. Some in vitro experiments demonstrated that DHA decreases the $\beta$ - and $\gamma$-secretase activity and increases the $\alpha$-secretase activity [100]. An in vitro study suggests that DHA reduced soluble $A \beta$ oligomers levels and inhibited the formation and polymerization of $A \beta$ fibrils [101]. Furthermore, DHA stimulated the $A \beta$ degradation [102] and disaggregation of preformed A $\beta$ fibrils in vitro [103].

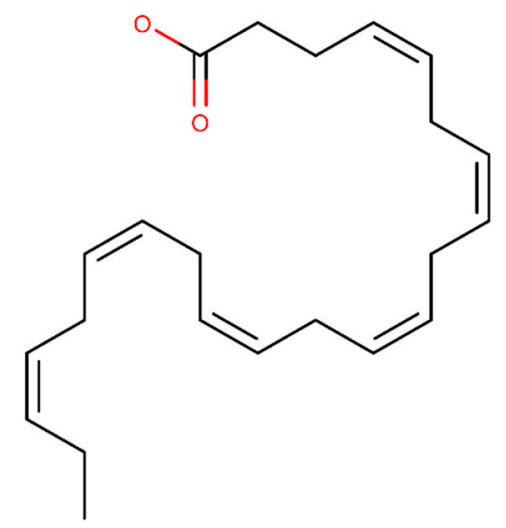

Figure 3. Chemical structure of docosahexaenoic acid (DHA).

The effects of supplementation with DHA in AD patients were studied in different clinical trials. In fact, Freund-Levi et al. (2006) conducted a double-blind, placebo-controlled clinical trial with 204 AD patients [44]. The main goal of this study was to evaluate the efficacy of dietary co-supplementation of DHA with other fatty acid, the eicosapentaenoic acid, on the cognitive functions of patients with mild to moderate AD. The patients were randomly divided in two groups, treatment and placebo. Patients on treatment group received a daily dose of $1.7 \mathrm{~g}$ of DHA and $0.6 \mathrm{~g}$ of eicosapentaenoic acid for six months. After this period, all patients received fatty acid co-supplementation for six more months. Despite the treatment being safe and well tolerated, the supplementation with these fatty acids did not delay the rate of cognitive decline of the patients.

Quinn et al. (2010) conducted a double-blind, placebo-controlled clinical trial to evaluate the efficacy of supplementation with DHA on the cognitive and functional decline in AD patients [45]. A daily dose of $2 \mathrm{~g}$ of DHA or placebo was administered to 295 patients for 18 months. The extent of brain atrophy was measured, and the results showed that DHA did not alter the patients' condition. The attained results also proved that administration of DHA did not slow the rate of cognitive and functional decline.

The same group conducted a double-blind, placebo-controlled, clinical study in the same year to evaluate the ability of DHA to improve the cognitive functions of 485 participants with age-related cognitive decline [46]. The subjects were randomly assigned to a daily oral administration of $900 \mathrm{mg}$ of DHA orally or placebo for 24 weeks. The attained results proved that supplementation with DHA improved cognitive health, since the participants showed enhanced learning and memory functions.

Lee et al. (2013) studied the effects of DHA administration using fish oil on the cognitive function in patients over 60 diagnosed with mild cognitive impairment [47]. The participants $(n=36)$ were randomly divided in two groups, placebo and treatment group. The treatment group was orally administered with $430 \mathrm{~g}$ of DHA three times a day, for one year. No significant side effects were verified, suggesting the potential of DHA to improve memory functions. However, studies with more patients and longer intervention periods, are necessary to define the optimal dosage. 
Homotaurine, also known as tramiprosate, is an aminosulfonate metabolite extracted from marine red alga Grateloupia livida and its structural formula is presented in Figure 4 [104]. In in vitro experiments, homotaurine proved to efficiently inhibit the $A \beta$ aggregation [105] and reduce the $A \beta$ plaque formation. This compound was also able to reduce the $A \beta$ levels in vivo [106]. Additionally, the compound stabilized $A \beta$ monomers and inhibited the $A \beta$ oligomers formation in vitro [107].

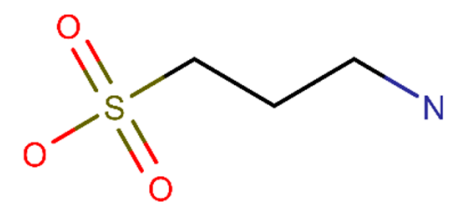

Figure 4. Chemical structure of homotaurine.

Aisen et al. (2011) conducted a phase III double-blind, placebo-controlled trial with 1052 patients with mild to moderate AD symptoms to evaluate the effect of homotaurine in slowing AD progression $[48,49]$. This compound was the first inhibitor of $\mathrm{A} \beta$ aggregation that has reached a phase III clinical trial. The participants were randomly divided in three groups. The first group was the placebo group, and the other two groups received daily treatment with homotaurine at dose of 100 and $150 \mathrm{mg}$ for 78 weeks, respectively. The authors proved that homotaurine administration had beneficial effect on cognition [108,109]

The safety and tolerability of this compound administered to 58 patients with mild to moderate AD symptoms, were studied previously in a phase II clinical trial conducted by the same group [50]. Patients received placebo, 100 or $150 \mathrm{mg}$ of homotaurine for three months. No harmful effects on vital signs were verified and the most frequent side effects were nausea, vomiting, and diarrhoea.

Martorana et al. (2014) conducted a study with 10 patients with mild cognitive impairment with ages between 59 and 74 [51]. The participants were administered daily with $100 \mathrm{mg}$ of homotaurine for four weeks. The obtained results showed that homotaurine improved the central cholinergic transmission.

Huperzine A is isolated from Huperzia serrata (Thunb.) Trevis. (Lycopodiaceae) and its structural formula is presented in Figure 5. This compound demonstrated to have antioxidant properties. Huperzine A was able to reduce ROS and lipid peroxidation in an AD rat model [110]. Also, this product presents the in vitro ability to increase the $\alpha$-secretase activity, significantly decreasing the $A \beta$ levels, suggesting a blocking action in the $A \beta$ production [111].

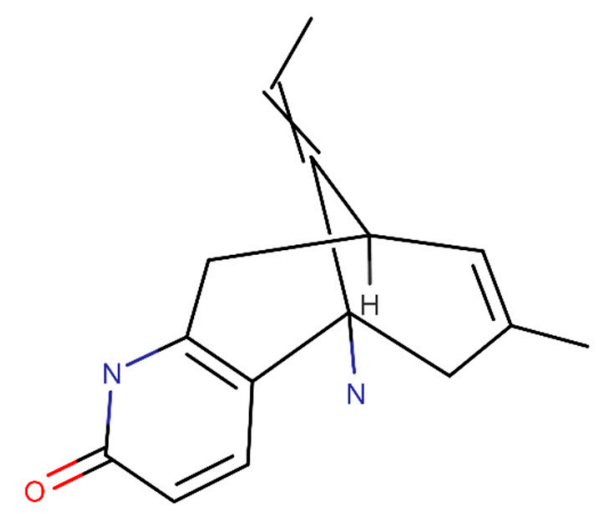

Figure 5. Chemical structure of huperzine A.

Xu et al. (1995) evaluated the efficacy and safety of huperzine A in AD patients. Four tablets of huperzine A $(200 \mu \mathrm{g})$ or placebo were administered orally to 103 patients, twice a day, for eight weeks [52]. The results showed that the administration of huperzine A improved the memory and behaviour of $\mathrm{AD}$ patients. Also, the obtained results for the compound were better than for placebo. Huperzine A did not induce side effects. 
To further compare the efficacy and safety of huperzine A administered into capsules and tablets in $\mathrm{AD}$ patients, the same group conducted a new trial four years later [53]. In this study, $200 \mu \mathrm{g}$ of huperzine A or placebo into capsules and tablets were administered twice a day to 60 patients, for 60 days. Both groups revealed a reduction in ROS levels in the plasma and erythrocytes of AD patients, without side effects besides nausea. This trial suggests that huperzine A in capsules and tablets is safe to be used in $\mathrm{AD}$ patients.

Later, Rafii et al. (2011) studied the safety and efficacy of two concentrations of huperzine A, 200 and $400 \mu \mathrm{g}$ twice a day, in patients with mild to moderate AD in a phase II clinical trial [54]. Placebo or huperzine A was administered to 177 patients for 16 weeks. The results demonstrated that at $400 \mu \mathrm{g} /$ day huperzine A was not efficient, not being able to treat AD. However, at the concentration of $800 \mu \mathrm{g} /$ day, the compound improved the cognition of AD patients. Huperzine A was safe at both studied doses.

Bryostatin is a macrolide lactone extracted from bryozoan Bugula neritina [112]. The structural formula of the compound is presented in Figure 6. An in vivo study showed that bryostatin reduced the $\mathrm{A} \beta$ production by the stimulation of $\alpha$-secretase activity, reducing the mortality of AD mice model [113]. Also, bryostatin revealed to enhance the learning and memory in AD mice model [114].

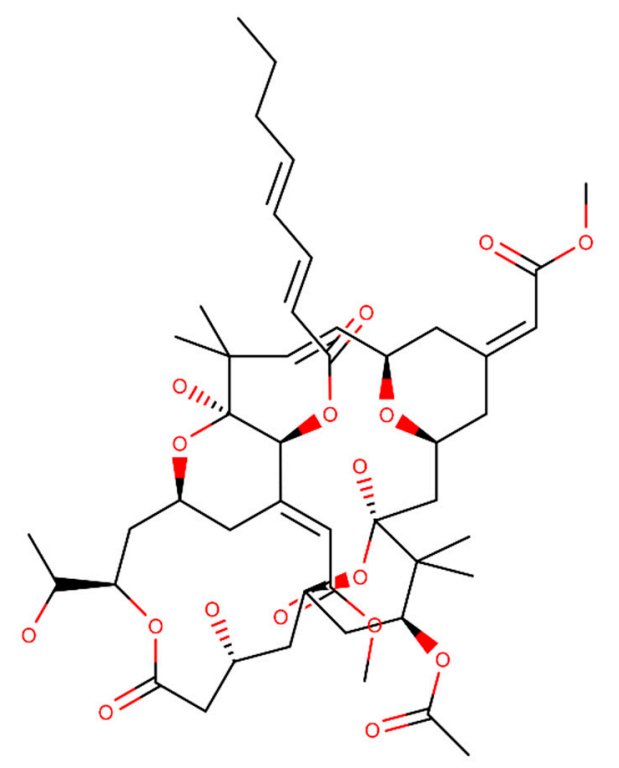

Figure 6. Chemical structure of bryostatin.

Recently, Nelson et al. (2017) evaluated the safety, tolerability and effects on cognitive function of bryostatin on AD patients in a phase II clinical trial [55]. A single dose of bryostatin at $25 \mu \mathrm{g} / \mathrm{m}^{2}$ was administered to six patients, while three patients received placebo. Bryostatin proved to improve cognitive functions and to be safe and well tolerated.

Another phase II clinical trial was performed with the same goals [56]. Farlow et al. (2018) administered 20 or $40 \mu \mathrm{g}$ of bryostatin or placebo to $150 \mathrm{AD}$ patients, for 12 weeks. This study confirmed the safety of both doses of bryostatin. Also, an improvement of cognitive functions was observed using doses of $20 \mu \mathrm{g}$ of bryostatin.

Melatonin is collected from animals, plants, fungi and bacteria and its structural formula is presented in Figure 7. This compound demonstrated to have antioxidant properties due to its ability to decrease ROS in vivo [115]. In addition, an in vivo study reported the beneficial effects on neuroinflammation [116]. Further, an in vitro study proved the ability to inhibit the $\beta$-sheet conformation and, consequently, $A \beta$ fibrils [117], decreasing the $A \beta$ levels in the brain of AD rat model [118]. Another in vitro study proved that melatonin inhibits $\beta$ - and $\gamma$-secretase activity and enhances the $\alpha$-secretase activity, blocking the $A \beta$ monomers production [119]. 


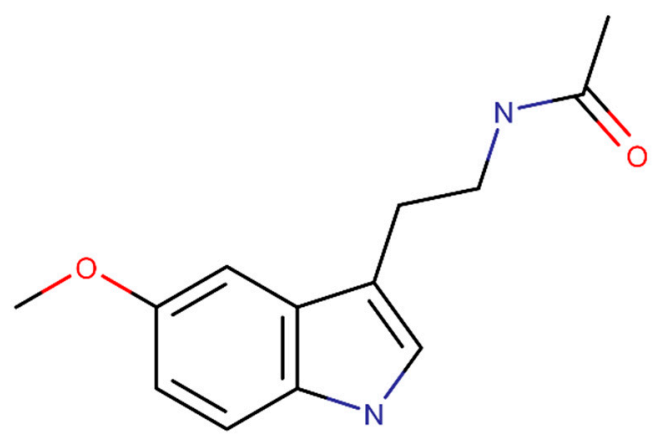

Figure 7. Chemical structure of melatonin.

Brusco et al. (1998) evaluated the efficacy of melatonin in monozygotic twins with AD, with similar cognitive and neuropsychologic impairments [57]. Only one of the twins orally received daily $6 \mathrm{mg}$ of melatonin for 36 months. The results suggest that melatonin improved the memory of the treated patient. Also, the clinical evaluation revealed that the twin that did not receive the treatment presented a more advanced state of the disease.

Later, the same group studied the effect of melatonin in cognitive dysfunctions of $14 \mathrm{AD}$ patients [58]. The patients received $9 \mathrm{mg}$ of melatonin daily for 22 to $35 \mathrm{months}$. The results showed an improvement in cognitive functions, after the treatment.

The same results were obtained by Furio et al. (2007) that performed a clinical trial with 50 outpatients diagnosed with mild cognitive impairment, where half of patients received 3 to $9 \mathrm{mg}$ of melatonin for 9 to 18 months [59].

Wade et al. (2014) investigated the ability of $2 \mathrm{mg}$ of melatonin to improve the cognitive functions of patients with mild to moderate AD [60]. Melatonin or placebo was administered to 80 patients for 24 weeks. Placebo was also administered two weeks before and after melatonin treatment. The results revealed an improvement in cognitive functions of $\mathrm{AD}$ patients treated with melatonin, comparing to placebo. Also, treatment was safe for both groups. Thus, these clinical trials suggested that melatonin administration can be a suitable therapeutic strategy for the treatment of AD.

Resveratrol is a naturally occurring non-flavonoid polyphenol present in grapes (Vitis vinifera $\mathrm{L}$. (Vitaceae)) and red wine and its structural formula is presented in Figure 8 [120]. In vitro experiments demonstrated that resveratrol induces the inhibition of studies proved a reduction of $A \beta$ fibrils formation [121] and induced the in vitro $A \beta$ disaggregation by an intracellular proteasomal action [108]. In vitro results showed that resveratrol has the ability to reshape toxic aggregates into a non-toxic aggregate type [109]. As result, resveratrol decreased the A $\beta$ levels [122] and plaque levels in brain of AD rats [123]. In addition, in vivo evidence suggests that resveratrol has anti-inflammatory [122] and antioxidant effects [124]. Also, an in vitro study showed that resveratrol prevents the tau hyperphosphorylation [125].<smiles>Oc1ccc(/C=C/c2cc(O)cc(O)c2)cc1</smiles>

Figure 8. Chemical structure of resveratrol. 
Turner et al. (2015) performed a phase 2 clinical trial for 52 weeks in mild to moderate AD patients. The group studied the safety, tolerability and the ability of resveratrol to reduce the biomarkers of the disease ( $\mathrm{A} \beta$ and tau). Here, 119 individuals were orally administered once a day with placebo or $500 \mathrm{mg}$ of resveratrol, with an increase of $500 \mathrm{mg}$ each 13 weeks. Although this study suggests that resveratrol can cross the blood-brain barrier (BBB), the results were not satisfactory. Besides inducing some side effects like nausea, diarrhea, and weight loss, the brain volume and biomarkers levels were lower in the placebo group than resveratrol group [61].

Recently, Zhu et al. (2018) evaluated the safety, tolerability and efficacy of a mixture containing $5 \mathrm{mg}$ of resveratrol, $5 \mathrm{~g}$ dextrose and $5 \mathrm{~g}$ of malate. Fifteen $\mathrm{mL}$ of the mixture or placebo were orally administered twice a day to 39 patients with mild to moderate AD for one year. The administration was done together with an $8 \mathrm{oz}$ glass of commercial grape juice. The results revealed that the preparation was safe and well tolerated. However, no evidence was observed concerning the efficacy of the product for AD therapy [62].

Nicotine is extracted from the tobacco plant leaves (Nicotiana tabacum L., Solanaceae) and its structural formula is presented Figure 9. Nicotine presents the ability to delay the amyloidogenesis by inhibiting the $\beta$-sheet structures in vitro [126], decreasing in vivo $\beta$-secretase expression [127] and inhibiting in vivo $A \beta$ aggregation [128]. An in vitro study revealed that nicotine inhibits the $A \beta$ fibrils formation and their length, and disaggregate $A \beta$ fibrils [129], causing an in vivo decrease of $A \beta$ [127] and plaque amounts [128]. In addition, an in vitro study suggested valuable effects of nicotine due to their antioxidant properties [130]. Also, the decrease of APP containing A $\beta$ peptide observed in in vivo experiments can be the reason to the diminution of $A \beta$ and amyloid plaque levels [131].

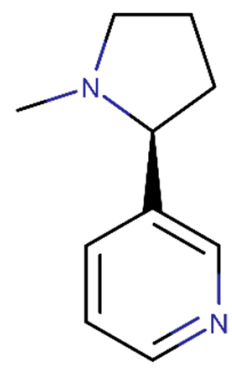

Figure 9. Chemical structure of nicotine.

Jones et al. (1992) studied the effect of nicotine on AD patients [63]. Three acute doses of nicotine $(0.4,0.6$ and $0.8 \mathrm{mg})$ were subcutaneously administered to $22 \mathrm{AD}$ patients and 48 controls. The results revealed that nicotine improved the perceptual and visual attentional deficits observed in AD patients.

The effect of nicotine on behaviour, cognition, and physiology of six AD patients was evaluated in a pilot study proposed by Wilson et al. (1995) [64]. Placebo, nicotine and washout were sequentially administered for seven, eight and seven days, respectively. After nicotine administration, an improvement in learning was observed, which persisted with washout. Memory, behaviour and cognition were not affected. Also, the safety of nicotine was proved.

The clinical and neuropsychological effects of nicotine was evaluated in eight AD patients by White et al. (1999) [65]. Transdermal nicotine was administered for two periods of four weeks, separated by two weeks of washout. A nicotine patch was used daily for $16 \mathrm{~h}$ with the following doses: $5 \mathrm{mg} /$ day in the first week, $10 \mathrm{mg} /$ day in the second and third week, and finally, $5 \mathrm{mg} /$ day in the fourth week. The results suggest that nicotine significantly improved the attentional performance. However, the limited sample of the study does not allow conclusive results.

Curcumin is an active component founded in the root of Curcuma longa L. (Zingiberaceae) and its structural formula is presented in Figure 10. This compound presents the in vivo ability to prevent the $A \beta$ aggregation and disaggregate preformed $A \beta$ fibrils $[132,133]$. Also, curcumin presents in vitro and in vivo anti-inflammatory and antioxidant beneficial effects, respectively [134,135]. Also, in vitro 
experiments showed that curcumin decreases $\beta$ and $\gamma$-secretase levels $[133,136,137]$. As result, the spatial learning of AD rat model was improved, as well as the memory impairment [133].

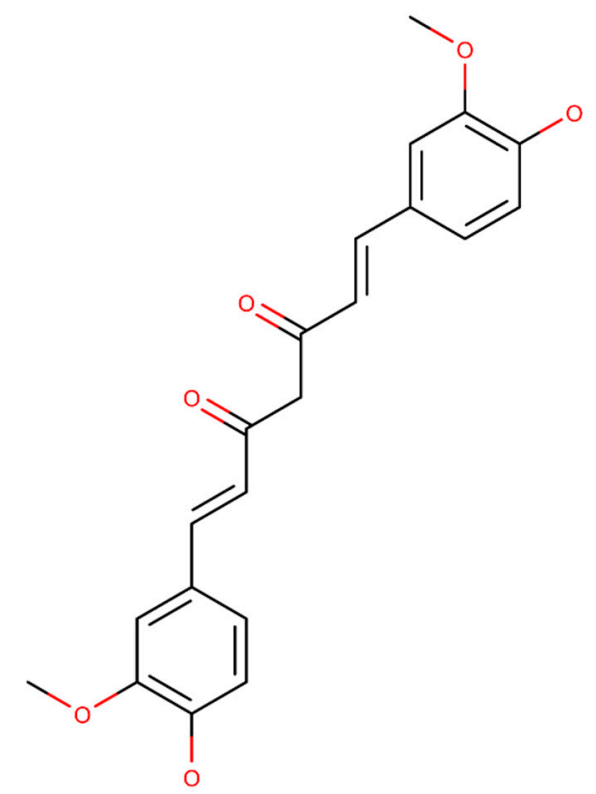

Figure 10. Chemical structure of curcumin.

Baum et al. (2008) performed a clinical trial to study the safety of curcumin on AD patients [66]. For six months, the authors administered $1 \mathrm{~g}, 4 \mathrm{~g}$ of curcumin or placebo in $34 \mathrm{AD}$ patients. The results proved that curcumin did not produce side effects in AD patients, but the authors revealed the necessity of additional trials to confirm the efficacy of curcumin in $\mathrm{AD}$ treatment.

\subsection{Natural Extracts and Other Natural Products}

Ginkgo biloba (Ginkgo biloba L., Ginkgoaceae) has been studied as therapeutic drug for AD and other neurological diseases therapy. In vitro evidence revealed that ginkgo biloba extract can prevent $A \beta$ aggregation, decrease $A \beta$ fibrillogenesis and destabilize preformed fibril [138]. Substantial in vivo experimental evidence indicates that ginkgo biloba has antioxidant [139] and anti-inflammatory properties, ameliorating the cognitive and memory impairment in an AD rat model [140]. In vivo studies showed that ginkgo biloba favors the non-amyloidogenic via of APP by increasing $\alpha$-secretase activity, inhibiting the $A \beta$ production [141,142].

Several clinical trials have been carried out in the last 10 years to test the viability of the compound in treating patients with dementia. Bachinskaya et al. (2011) examined the effect of gingko biloba extract EGb $761^{\circledR}$ on neuropsychiatric symptoms of dementia $[67,68]$. Outpatients with mild to moderate dementia (AD with or without cerebrovascular disease or vascular dementia) $(n=410)$ were considered in this study. Patients received $240 \mathrm{mg}$ of extract or placebo once daily for 24 weeks. The treatment with gingko biloba was safe and improved the neuropsychiatric symptoms, which include apathy, irritability, depression, among others.

Also, with the same conditions, Herrschaft et al. (2012) revealed that the treatment with gingko biloba improved the cognition and the life quality of patients [69].

Ihl et al. (2012) performed a similar 24-week randomised controlled trial involving 404 outpatients [70]. Patients were diagnosed with $\operatorname{AD}(n=333)$ or vascular dementia $(n=71)$. In addition to confirming the improvement of neuropsychiatric symptoms observed in the previous trial, the extract improved the cognitive functions and functional abilities of patients.

Gavrilova et al. (2014) also conducted a clinical trial to study the effects of gingko biloba in neuropsychiatric symptoms and cognition in 160 patients with mild cognitive impairment [71]. 
The patients received $240 \mathrm{mg}$ of EGb $761^{\circledR}$ or placebo for 24 weeks. The trial proved that the extract improved the neuropsychiatric symptoms and cognitive functions of patients. Also, the extract was safe and well tolerated. Taking together, the last clinical trials proved that a $240 \mathrm{mg}$ daily dose of ginkgo biloba extract is safe in the treatment of dementia.

Saffron (Crocus sativus L., Iridaceae) is a stem-less herb with antioxidant [143] and anti-inflammatory activities in vivo [144]. This product inhibited the in vitro $A \beta$ aggregation and fibrillogenesis [145].

Akhondzadeh et al. (2010) evaluated the efficacy of $30 \mathrm{mg}$ saffron in the treatment of mild to moderate AD [72]. Saffron or placebo were orally administered daily for 16 weeks, to 46 patients. The phase II study showed that the administration of saffron improved the cognition and memory of AD patients. Also, no side effects differences were observed with saffron or placebo administration. Thus, saffron seems to be safe in the treatment.

Lemon balm (Melissa officinalis L., Lamiaceae) from the mint family that is native to Europe with antioxidant activity in vitro [146]. In vivo studies proved the ability of lemon balm extract to improve the memory of an AD model, probably due to the inhibition of $\beta$-secretase activity [147]. To assess the efficacy and safety of Melissa officinalis extract on patients with mild to moderate AD, Akhondzadeh et al. (2013) administered to 40 patients 60 drops of extract or placebo, for four months [73]. The results proved that Melissa officinalis extract ameliorated the cognition and agitation of AD patients.

Green tea (Camellia sinensis (L.) Kuntze, Theaceae) from steaming and drying of leaves of the Camellia sinensis plant proved to be a rich source of antioxidants in in vivo studies [148]. In addition, the green tea prevented the spatial learning and memory destruction in an AD mice model by decreasing $A \beta$ oligomers levels [149] and hyperphosphorylated tau protein [150].

Recently, Arab et al. (2016) developed a clinical trial with 30 patients to study the antioxidant activity of green tea in patients with severe AD and its ability to improve cognitive functions [74]. Patients received daily $2 \mathrm{~g}$ of green tea through the ingestion of pills, for two months. The results showed an improvement on cognitive functions, confirming the effects of the antioxidant activity of green tea.

Papaya (Carica papaya L., Caricaceae) is a fruit often used in medicine that has amino acids, $\beta$-carotene, oligosaccharides and vitamins, with benefits in AD.

A clinical trial performed by Barbagallo et al. (2015) studied the antioxidant activity of fermented papaya powder extract in $\mathrm{AD}$ patients [75]. AD patients $(n=20)$ received $4.5 \mathrm{~g}$ of extract daily for six months, while the 12 controls did not receive any treatment. The results showed that the supplementation with fermented papaya powder reduced the ROS generation and nitric oxide production in AD patients, with no significant changes in controls. Thus, the papaya can be used as antioxidant in the AD therapy.

Sage (Salvia officinalis L., Lamiaceae) is a medicinal plant with a long-standing reputation in European medical herbalism due to its anti-inflammatory and antioxidant properties observed in vivo [151].

Akhondzadeh et al. (2008) developed a clinical trial to evaluate the efficacy and safety of Salvia officinalis extract in the treatment of patients with mild to moderate AD [76]. Patients received daily 60 drops of sage extract or placebo for four months. The results showed that sage extract improved cognitive functions. Also, after the treatment, any group revealed side effects except agitation, that seems to be more pronounced in placebo group. This study proved that sage can be useful in the therapy of mild to moderate AD.

Coconut (Cocos nucifera L., Arecaceae) demonstrated to be able to reduce the A $\beta$ deposition and aggregation and the oxidative stress in a transgenic Caenorhabditis elegans AD model [152]. Coconut oil also enhanced the memory of rats [153]. Also, in vitro studies demonstrated that the coconut oil reduced de APP expression, decreasing the A $\beta$ secretion [154] and protected neuronal cells against $\mathrm{A} \beta$-induced neurotoxicity.

Ortí et al. (2018) performed a clinical trial with 44 AD patients [77]. Half of individuals received daily $40 \mathrm{~mL}$ of coconut oil, distributed by the breakfast $(20 \mathrm{~mL})$ and lunch $(20 \mathrm{~mL})$, for 21 days. Before 
and after the oil administration, cognitive function was evaluated. The trial revealed that the patients treated with coconut oil demonstrated an improvement of cognitive functions.

Apple (Malus domestica Borkh., Rosaceae) showed to be a promising approach to prevent AD. In vivo evidence demonstrated that the apple extract prevents the oxidative stress and reduces the $A \beta$ levels, improving the memory of AD rats [155]. Besides, in vivo studies demonstrated that apple juice is able to reduce $\gamma$-secretase expression, which leads to the reduction of $\mathrm{A} \beta$ production [156].

Remington et al. (2010) performed an open-label pilot clinical trial with 21 patients with moderate to severe $\mathrm{AD}$ [78]. The authors administered two 4-oz of apple juice daily for one month. Although the results suggest that there was no modification in the degree of dementia, a significant improvement in behavioural and psychotic symptoms was observed, with reduction of anxiety, agitation, and delusion. This study suggests that the supplementation with apple juice can attenuate the AD-related decline.

Blueberry (Vaccinium myrtillus L., Ericaceae) is a fruit composed by several polyphenols named anthocyanins, with antioxidant [157] and anti-inflammatory properties in vivo [158]. In vitro works suggested that blueberries increase the $A \beta$ clearance [159] and inhibit the $A \beta$ aggregation, decreasing the amount of toxic species [157]. As a result, an improvement in cognitive functions and motor performance was observed in an AD mouse model [160].

Krikorian et al. (2010) evaluated the effects of daily administration of wild blueberry juice in a group of nine elderly subjects with early memory failures [79]. The daily consumption of blueberry juice was proportional with body weight, varying between 6 and $9 \mathrm{~mL} / \mathrm{kg}$. After 12 weeks of treatment, an improvement in learning was observed as well as a reduction of depressive symptoms. The study suggests that the blueberry supplementation can confer neuroprotection.

Colostrinin, a milk form produced by mammary glands [161], presents in vitro antioxidant and anti-inflammatory activities, and inhibits the $\mathrm{A} \beta$ fibrils formation and disassembles $\mathrm{A} \beta$ aggregates [162]. Also, the ability of colostrinin to inhibit tau phosphorylation and eliminate $\mathrm{A} \beta$ was proved in vitro [163].

The effect of colostrinin on AD patients was studied in a clinical trial conducted by Szaniszlo et al. (2009) [80]. Patients over 50 received $100 \mu \mathrm{g}$ of colostrinin or placebo for 15 weeks. The results showed an enhancement in cognitive and daily function of $\mathrm{AD}$ patients treated with colostrinin. Thus, this compound can be a suitable approach for AD therapy.

\section{Preclinical In Vivo Studies of Natural Compounds and Their Effects on AD}

Besides the natural compounds that have been studied in clinical trials, several other products have proved to have a potential beneficial effect in AD therapy in a preclinical stage, namely in in vivo studies. The preclinical phase involving in vivo studies is conducted to assess if the new compounds are safe and effective, before they can proceed to the clinical trials phase. A detailed report of animal studies results is described below. The natural compounds were divided into two groups: bioactive compounds and natural extracts and organized by the number of mechanisms associated with AD therapy, from the highest to the least.

\subsection{Bioactive Compounds}

Epigallocatechin gallate (EGCG) is a polyphenol found in green tea with several neuroprotective effects in AD. In vivo evidence suggests that EGCG decreased $\beta$ - and $\gamma$-secretase actions and enhanced the $\alpha$-secretase activity, leading to the decrease of $A \beta$ levels improving the memory [164]. Besides that, EGCG inhibited the in vitro $A \beta$ aggregation [165] and the in vivo $A \beta$ oligomerization [166]. Moreover, EGCG inhibited the in vitro tau aggregation [167] and increased the in vivo clearance of phosphorylated tau [168]. Lastly, EGCG has been reported in in vivo experiments to demonstrate antioxidant [169] and anti-inflammatory actions [170].

Retinoic acid is a terpenoid and a metabolite of vitamin $A$. In vitro studies revealed that retinoic acid inhibited $A \beta$ fibrils formation and their extension and destabilized $A \beta$ fibrils [171]. In vitro evidence demonstrated that retinoic acid decreases the $A \beta$ levels by inhibiting $\beta$ - [172] and $\gamma$-secretase [173] and increasing $\alpha$-secretase activity [172]. An in vivo study reported the ability of retinoic acid reducing 
brain A $\beta$ deposition, APP phosphorylation and tau phosphorylation. This work also proved the anti-inflammatory activity of this compound, improving the learning and memory of AD mice model [174].

Caffeine is perhaps the most consumed psychoactive compound. It is present in the coffee bean, but it can be also found in some teas, cocoa drinks, candy bars, among other herbs. In vivo studies suggest that caffeine reduced the $\beta$-secretase and $\gamma$-secretase levels, decreasing the $A \beta$ production [175]. An in vitro study showed that the inhibition of the $\beta$-sheets conformation can be related with the ability of caffeine to reduce $A \beta$ levels [176]. Also, it was observed in vivo that this natural product promotes $\mathrm{A} \beta$ clearance [177]. In vivo evidence suggested that caffeine have anti-inflammatory and antioxidant properties [178]. In vivo studies demonstrated that the improvement observed in the memory could result from hippocampal tau phosphorylation reduction [179].

Baicalein is a naturally occurring flavonoid from the roots of Scutellaria baicalensis Georgi (Lamiaceae). In vitro studies suggested that baicalein inhibits the ROS production, reducing the oxidative stress [180]. In vitro results proved that baicalein inhibits $A \beta$ fibrillation and oligomerisation and disaggregates $A \beta$ fibrils [181]. In vivo studies proved that baicalein is able to increase the $\alpha$-secretase and decrease the $\beta$-secretase activities, reducing the $\mathrm{A} \beta$ production $[182,183]$. Also, the tau phosphorylation in AD model mice was prevented and the cognitive function improved [183].

Berberine is an isoquinoline alkaloid found in rhizoma coptidis, an herb frequently used in Chinese herbal medicine. In vivo evidence suggests that berberine inhibited the $\beta$-secretase expression, reducing the $A \beta$ production. Also, berberine stimulated the $A \beta$ clearance and inhibited the $A \beta$ plaque deposition and hyperphosphorylation of APP and tau [184]. Berberine has been also described as having in vivo anti-inflammatory and antioxidative activities [185].

Kaempferol is a polyphenolic flavonoid found in fruits, vegetables and herbs. In vivo studies proved its antioxidant effect, improving the learning and memory of a transgenic drosophila AD model [186]. Also, in vitro evidence showed that kaempferol has anti-inflammatory activity [187], inhibits A $\beta$ aggregation [188] and destabilizes A $\beta$ fibrils [189]. Also, another in vitro study proved that kaempferol inhibits the $\beta$-secretase activity [190].

Quercetin is a flavonol, naturally occurring polyphenolic compounds present in fruits, vegetables and herbs. In vivo studies showed that quercetin improved the memory and cognitive impairments of an AD model and reduced the oxidative stress [191]. Moreover, in vitro evidence suggested that quercetin prevents the $A \beta$ aggregation [192], inhibits the $A \beta$ fibrils formation and destabilizes $A \beta$ fibrils [193], decreasing the A $\beta$ levels in brain of AD model mice [194]. Additionally, this compound was reported in in vivo studies as inhibitor of $\beta$-secretase and taupathy [195].

Fisetin is a flavonoid extracted from Rhus succedanea L. (Anacardiaceae) and also found in some fruits and vegetables. Fisetin proved to inhibit $A \beta$ aggregation in vivo [196] and fibril formation in vitro [188], reducing the in vivo $A \beta$ accumulation [197]. Also, an in vivo experiment described fisetin as a $\beta$-secretase inhibitor and anti-inflammatory product [197]. Additionally, fisetin promotes the in vitro degradation of phosphorylated tau [198] and reduced the in vivo tau hyperphosphorylation [197].

Oleuropein is a polyphenol present in extra virgin olive oil with antioxidant [199] and anti-inflammatory properties in vivo [200]. The A $\beta$ levels and amyloid plaque load were reduced in vivo, resulting in an amelioration of cognitive functions [201]. Also, the compound inhibited the A $\beta$ aggregation in vivo [200], favouring the formation of non-toxic aggregates in vitro [202]. Additionally, in vitro evidence suggested that oleuropein decreased the $A \beta$ oligomers levels through the promotion of $\alpha$-secretase activity [203]. Lastly, oleuropein was described as tau aggregation inhibitor in vitro [204].

Tannic acid is a polyphenol found in herbs and fruits. An in vivo experiment showed that tannic acid is a natural inhibitor of $\beta$-secretase with anti-inflammatory properties, preventing the cognitive impairment of AD mice [205]. One in vitro study affirmed that tannic acid inhibits $A \beta$ formation associated with less amyloidogenic APP proteolysis, inhibits A $\beta$ fibrils formation as their extension and still destabilizes A $\beta$ fibrils [206]. Another in vitro study demonstrated that tannic acid inhibits the tau aggregation [207]. 
Crocin is a carotenoid mainly found in the stigma of saffron flower. In vitro experiments showed that crocin inhibits the $A \beta$ fibril formation [208] through the inhibition of the $A \beta$ fibrillogenesis [145]. Also, in vitro evidence suggests that crocin reduces the number of fibrils as well as their length [208]. An in vitro study confirmed that crocin can also disrupt $A \beta$ aggregates [209]. Also, the therapeutic effects of crocin can be linked to its antioxidant [210] and anti-inflammatory activities [211] observed in in vivo studies.

Epicatechin represents one of the antioxidants from the flavonoids family. High amounts of this compound can be found in cocoa beans, green tea and grapes. In vivo data showed that epicatechin has antioxidant [212] and anti-inflammatory activities [213]. Further, in vitro studies suggest that epicatechin is an inhibitor of $\beta$-secretase [214]. As result, epicatechin decreased the $A \beta$ levels in an AD mice model [212]. Also, epicatechin has the in vitro ability to inhibit tau aggregation [215] and fibril formation changing the secondary structure [216].

Gallic acid is a phenolic acid present in fruits, vegetables and herbs. Gallic acid proved to have antioxidant [217] and anti-inflammatory activities, improving the learning and memory in vivo [218]. Also, gallic acid can reduce the in vitro $A \beta$ aggregation by the inhibition of conformational transition to $\beta$-sheet [219]. An in vivo experiment observed a reduction in $A \beta$ levels after gallic acid administration due to the increase of $\alpha$-secretase action, promoting the non-amyloidogenic route and consequently the decreases the $\mathrm{A} \beta$ oligomerization [220].

Ferulic acid is a phenolic compound naturally present in numerous fruits and vegetables. In vivo results revealed that ferulic acid is an antioxidant [221] and anti-inflammatory compound [222]. Also, it can reduce the in vivo $A \beta$ production by reducing the $\beta$-secretase activity [222]. The decrease of $\beta$-sheets structures was also observed in an in vitro experiment, inhibiting the $A \beta$ aggregation [223]. Additionally, ferulic acid decreased the $A \beta$ deposition and improved the cognitive performance of an AD mouse model [224]. Also, ferulic acid decreased the A $\beta$ fibrils levels in vitro [225].

Rutin is a bioflavonoid extracted from some vegetables and fruits. This product is a glycoside of the flavonoid quercetin with antioxidant and anti-inflammatory properties in vivo [226]. The same in vivo study showed that this compound inhibited the $A \beta$ aggregation [226]. Also, rutin decreased the $A \beta$ fibrils formation in vitro [193]. This can be due to its ability to inhibit the $\beta$-secretase activity in vitro [193]. Also, rutin disaggregated A $\beta$ fibrils in vitro [193].

Salvianolic acid B is a phenylpropanol founded in the Salvia miltiorrhiza Bunge (Lamiaceae) root. In vivo experiments showed a strong antioxidant and anti-inflammatory activities, improving the memory and learning of an AD mouse model [227]. Also, salvianolic acid B inhibited the A $\beta$ aggregation and disaggregated preformed $A \beta$ fibrils in vitro [228]. Another in vitro work suggested that salvianolic acid $B$ inhibits the $\beta$-secretase which leads to the inhibition of $A \beta$ production [229].

Myricetin is a flavonoid extracted from several fruits, vegetables and herbs. In vitro proofs showed that myricetin prevents $A \beta$ aggregation and consequent fibrillation $[189,230]$ due to its capacity to inhibit $\beta$-secretase and increase the $\alpha$-secretase activity [231]. Also, myricetin blocked the structural changes on $A \beta$ in vitro, inducing a reduction in $A \beta$ levels [231]. Also, the disaggregation of $A \beta$ fibrils was observed in vitro [189]. As result, an in vivo study showed that myricetin enhanced the learning and memory impairments in an AD rat model [232].

Naringenin is a natural compound present in citrus fruits and tomatoes. It is the major flavanone constituent found in Citrus junos Siebold ex Tanaka, Rutaceae. An in vitro study revealed that naringenin inhibited the APP and $\beta$-secretase activity and reduced the levels of phosphorylated tau [233]. As result, brain levels of $A \beta$ were reduced in vivo [234]. In vivo evidence also proved the antioxidant [235] and anti-inflammatory activities of the compound, improving motor coordination, learning and memory of $\mathrm{AD}$ rats [236].

Luteolin, a polyphenol flavonoid found in fruits, vegetables and herbs, exhibits potent anti-inflammatory activity in vitro [237] and antioxidant activity against induced-oxidative stress in a in vivo AD model [238], ameliorating the spatial learning and memory impairment [239]. An in vitro 
study also proved that this compound is a potent inhibitor of $\beta$-secretase [240]. Another in vitro study demonstrated that luteolin is able to reduce tau hyperphosphorylation [241].

Asiatic acid is a pentacyclic triterpene found in plants. Asiatic acid demonstrates an ability to inhibit the $\beta$-secretase and increase the $\alpha$-secretase activity in vitro. Also, it demonstrates an ability to activate $A \beta$ clearance [242], which explains the substantial reduction in A $\beta$ levels in AD mice [243]. Numerous in vivo works suggest that asiatic acid has antioxidant properties, clearing free radicals and decreasing lipid peroxidation, improving the learning and memory [244].

Puerarin is an isoflavanone glycoside isolated from Pueraria lobata (Willd.) Ohwi (Leguminosae) used to treat some diseases. In vivo studies found that puerarin inhibited the tau phosphorylation and reduced $A \beta$ levels, ameliorating the spatial learning and memory in an AD mice model [245]. The beneficial effects of puerarin were suggested in in vivo experiments to be connected to its ability to reduce the oxidative stress [246] and neuroinflammation [247].

Oleocanthal is one of the main active components of extra virgin olive oil. In vitro evidence suggests that this compound changes the structure of tau protein, inhibiting its aggregation [248] and fibrillization [249]. In vivo results proved that oleocanthal enhances the $A \beta$ clearance, reducing the amyloid load. Also, the anti-inflammatory activity of the compound was verified [250].

Viniferin (trans $\mathcal{\varepsilon}$-viniferin) is a polyphenol present in a variety of vines, including Vitis vinifera L., Vitaceae. In vitro evidence proved the anti-inflammatory [251] and antioxidant [252] activities of the compound. Also, viniferin disaggregated $A \beta$ [251] and inhibited the $A \beta$ aggregation, reducing the fibril formation [253].

Scyllo-inositol, also known as scyllo-cyclohexanehexol, is one of the stereoisomers of inositol, found in dogwood Cornus florida L. (Cornaceae) and coconut palm Cocos nucifera L. (Arecaceae). An in vivo study showed that this compound decreases the $A \beta$ levels and inhibits the $A \beta$ aggregation, improving the memory of AD rat model [254]. In vitro evidence demonstrated that scyllo-inositol induces structural modifications in $\mathrm{A} \beta$, stabilizes $\mathrm{A} \beta$ oligomers and inhibits fibril formation [255].

Honokiol is a poly-phenolic product found in Magnolia officinalis Rehder \& E.H.Wilson, Magnoliaceae. In vivo evidence suggested that honokiol is an antioxidant [256] and anti-inflammatory compound [257]. In vivo studies revealed that honokiol inhibits the $\beta$-secretase activity, reducing the $\mathrm{A} \beta$ production and senile plaque deposition. Also, the $\mathrm{A} \beta$ degradation was enhanced by honokiol [257]. As result, honokiol decreased $A \beta$-induced hippocampal neuronal apoptosis, improving learning and memory of AD mice model [256].

Apigenin is a flavonoid found in plants, fruits and vegetables. Numerous in vitro and in vivo works showed its anti-inflammatory [258] and antioxidant [259] properties, respectively. An in vivo experiment proved that apigenin changes APP processing by the $\beta$-secretase inhibition preventing the $\mathrm{A} \beta$ deposition and consequently, improving the memory impairments [259].

Caffeic acid is a phenolic acid present in food, beverages and Chinese herbal medicines with antioxidant and anti-inflammatory properties in vivo. This compound improved the learning of AD rat models [260]. In vitro studies showed that caffeic acid reduced the tau phosphorylation and protected the PC12 cells against A $\beta$-induced toxicity [261].

$\beta$-carotene belongs to the carotenoid family. One in vitro study reported that $\beta$-carotene has an anti-aggregation activity and destabilizes $A \beta$ [171]. Another in vivo study demonstrated the $\beta$-carotene has the ability to reduce oxidative stress, by reducing the ROS production [262].

Rosmarinic acid is a phenolic carboxylic acid found in rosemary, lemon balm and peppermint, among others. An in vivo study proved that this compound has antioxidant properties, protecting an AD mouse model against memory deficits [263]. Also, rosmarinic acid inhibited the tau hyperphosphorylation [264] and fibrillization in vitro [265].

Nordihydroguaiaretic acid (NDGA) is a compound found in Larrea divaricata Cav. (Zygophyllaceae) with in vivo antioxidant properties [266]. An in vitro study reported that NDGA inhibits the A $\beta$ fibrils formation, reducing the number of fibrils and small amorphous aggregates. Additionally, this compound disrupts $\mathrm{A} \beta$ fibrils [267]. 
Osthole is a coumarin isolated from Cnidium monnieri (L.) Cusson (Apiaceae). An in vivo study showed that this compound significantly enhanced the memory of an AD rat model, that can be linked to its antioxidant activity [268] and with a reduction of $A \beta$ levels found in the brain. This reduction can be due to the inhibition of $\beta$-secretase in vitro [269]. Also, in vitro evidence suggests that this product decreases the phosphorylated tau levels [270].

Ellagic acid is a polyphenol extracted from Punica granatum L. (Lythraceae). An in vitro study proved that this compound inhibits of $\beta$-secretase activity preventing neurotoxicity [271]. Ellagic acid has antioxidant and anti-inflammatory properties, that improve learning and memory injuries in $A D$ rat model [272].

Glycine betaine is an organic osmolyte, which could be isolated from vegetables and marine products. In vivo evidence revealed that glycine betaine reduces tau hyperphosphorylation and $A \beta$ production, improving memory deficits [273]. Also, glycine betaine inhibited the $\beta$-secretase activity and activated the $\alpha$-secretase activity in vitro, thereby inhibiting the $\mathrm{A} \beta$ production [274].

Hydroxytyrosol is a phenolic compound extracted from the olive leaf and oil. In vivo studies demonstrated that it is a compound with antioxidant and anti-inflammatory properties [275]. Also, hydroxytyrol showed to reduce the levels of $\mathrm{A} \beta$ plaques in an AD mice model [276].

L-theanine is an amino acid present in green tea. An in vivo work showed that L-theanine decreased the oxidative stress and the A $\beta$ levels [277]. Also, this natural product proved to inhibit tau hyperphosphorylation in vitro [278].

13-Desmethyl spirolide $C$ is a marine compound belonging to the cyclic imine group produced by the dinoflagellate Alexandrium ostenfeldii and accumulate in shellfish. An in vitro study revealed that 13-desmethyl spirolide $C$ is a spirolide that can reduce intracellular $A \beta$ accumulation and hyperphosphorylated tau levels [279]. The reduction of intracellular A $\beta$ levels was also observed in an in vivo study [280].

Gossypin is a flavonoid found in Hibiscus vitifolius L. (Malvaceae) and has been reported in in vivo experiments to exhibit anti-inflammatory [281] and antioxidant actions [282].

Gypenosides are triterpenoid saponins extracted from Gynostemma pentaphyllum (Thunb.) Makino (Cucurbitaceae) and they are reported in an in vivo study to be products with antioxidant and anti-inflammatory activities, improving the cognitive impairment [283].

1,2,3,4,6-Penta-O-galloyl- $\beta$-D-glucopyranose (PGG) is a polyphenol and the main constituent of the Paeonia $x$ suffruticosa Andrews (Paeoniaceae) root, a tree peony native to China and used in traditional medicine practices. In vivo experiments proved that PGG inhibits the $A \beta$ oligomerization, which prevents $A \beta$ fibril formation, resulting in the decrease of $A \beta$ levels and improvement of memory. PGG is also able to promote the destabilization of $A \beta$ fibrils [284].

Enoxaparin is a low molecular weight heparin present in the intestinal mucosa of pigs. Enoxaparin reduced the $A \beta$ load through the decreasing of $\beta$-secretase activity [285]. Also, enoxaparin has anti-inflammatory activity in vivo [286], improving the cognition of an AD mice model [287].

Morin, a natural flavonoid mainly found in Maclura pomifera (Raf.) C. K. Schneid. (Moraceae), Maclura tinctoria (L.) D. Don ex Steud. (Moraceae) and leaves of Psidium guajava L. (Myrtaceae), promoted the inhibition of $\beta$-secretase activity in vitro [190]. Besides, morin is able to reduce tau hyperphosphorylation in vivo [288].

Naringin is a flavonoid present in citrus fruits, namely in grapefruit. In vivo studies suggested that the antioxidant and anti-inflammatory activities of this compound improved the learning and memory of AD rats [289].

Vanillic acid is a phenolic acid extracted from the plant Angelica sinensis (Oliv.) Diels (apiaceae) with antioxidant and anti-inflammatory activities in vivo. As a result, an improvement in learning and memory of AD rats was observed [290].

Punicalagin is an ellagitannin found in the fruit peel of pomegranate (Punica granatum L. (Lythraceae)). In vivo studies suggest that punicalagin has potential as a nutritional preventive 
strategy in AD due to its anti-inflammatory activity. This natural product favors the anti-amylogenic route through the inhibition of $\beta$-secretase, reducing $A \beta$ levels [291].

Piperine is a nitrogenous alkaloid found in fruits of the family piperaceae, including in piper nigrum L. and piper longum L. This compound has been used in traditional medicine to cure several diseases. In vivo trials reported that the reduction of lipid peroxidation can be linked with the neuroprotective effects of this compound [292], resulting in a significant improvement in memory of AD rat model [293].

Rhodosin is a flavonol extracted from the root of Sedum roseum (L.) Scop. (Crassulaceae) that improved the learning and memory injuries in an AD rat model due to its antioxidant activity [294].

\subsection{Natural Extracts and Other Natural Products}

Garlic (Allium sativum L., Amaryllidaceae) is frequently used in culinary and medicine. Several studies showed that the administration of aged garlic extract significantly improves the memory deficit by several pathways. In vitro studies demonstrated that aged garlic extract has antioxidant properties [295], inhibits $A \beta$ fibril formation through the inhibition of $A \beta$ aggregation [296] and it is able to defibrillate $A \beta$ fibrils [296]. In addition, in vivo evidence showed that aged garlic extract has anti-inflammatory properties [297], increases the $\alpha$-secretase activity and inhibits tau hyperphosphorylation [298].

Cinnamon (Cinnamomum verum J. Presl., Lauraceae) is one of the most used spices and has been traditionally applied in the treatment of some diseases and their symptoms. Cinnamon extract is found to inhibit in vitro tau aggregation and promote the disassembly of tau filaments [215]. Other in vitro studies suggested that the potential therapeutic effect of cinnamon against $A D$ can also be due to its anti-inflammatory activity [299]. In vivo evidence showed that cinnamon extract has antioxidant activity [300], prevents $A \beta$ oligomerization [301], reducing the $A \beta$ level and correcting the cognitive impairment of transgenic mice [300].

Olive (Olea europaea L., Oleaceae) is the source of olive oil, one of the most important ingredients in the Mediterranean diet. In vivo studies showed that extra virgin olive oil ameliorated behavioural impairments. Also, the oil reduced the $A \beta$ and phosphorylated tau levels [302]. This decrease can be due to the increase of $A \beta$ clearance and APP modulation [303]. In vivo studies also proved its antioxidant activity, protecting against A $\beta$-induced cytotoxicity [304].

Walnut (Juglans regia L., Juglandaceae) is a dried fruit composed by fatty acids, vitamins, alpha tocopherol, and polyphenols, in particular ellagic acid. An in vitro study showed that walnut extract inhibited the $A \beta$ fibril formation through the inhibition of $A \beta$ fibrillation, and also defibrillated $A \beta$ fibrils [305]. Additionally, in vivo studies demonstrated that walnut extract reduced the oxidative stress and neuroinflammation induced by $\mathrm{A} \beta$ in an AD mice model [306].

Grapes (Vitis vinifera L., Vitaceae) are composed by several polyphenols including catechin, epicatechin, epigallocatechin and epicatechin gallate. In vivo studies have revealed that grape seed extract increases the memory performance and reduces ROS production, thereby protecting the central nervous system [307]. An in vitro work revealed that grape seed extract blocks the A $\beta$ fibril formation [308] through the inhibition of $A \beta$ aggregation [309]. Therefore, the amount of amyloid plaques in the brain of $\mathrm{AD}$ mice was reduced. Besides, grape seed extract can attenuate the neuroinflammation in vivo [310]. In vivo works proved that the grape skin extract has antioxidant property [311] and inhibits the in vitro $A \beta$ fibril formation [121,312].

Pomegranate (Punica granatum L., Lythraceae) is a fruit with a variety of antioxidant polyphenols. Pomegranate juice reduced the $\mathrm{A} \beta$ levels and amyloid plaques in an $\mathrm{AD}$ mouse model, improving spatial learning and cognitive performance [313]. Further in vivo analysis revealed that these results could be the product of the inhibition of $\gamma$-secretase activity [314]. In addition, in vivo studies demonstrated that pomegranate has anti-inflammatory [315] and antioxidant activities [316].

Skullcap (Scutellaria baicalensis Georgi, Lamiaceae) is a native American plant commonly used in traditional Chinese medicine. An in vivo study found that skullcap was able to protect 
hippocampal neurons against $A \beta$-induced damage through the attenuation of oxidative stress and neuroinflammation [317].

Strawberry (Fragaria $x$ ananassa (Weston) Duchesne, Rosaceae) is known to contain high phenolic contents. In vivo studies showed that strawberries have anti-inflammatory [318] and antioxidant activities, protecting against oxidative stress [319].

Moringa (Moringa oleifera Lam., Moringaceae), an Asian and African plant, presents several nutrients, including $\beta$-carotene, vitamin $C$ and $\mathrm{E}$ and phenols, including quercetin and kaempferol. In vivo studies showed that this plant improved the memory and learning due to its antioxidant activity [320].

\section{Preclinical In Vitro Studies of Natural Compounds and Their Effects on AD}

Besides the aforementioned natural compounds studied in human and animal studies, several other products have gained an increasing interest in scientific community for AD therapy. In fact, different compounds were tested in vitro and showed promising results. Some compounds proved to be efficient in preventing the formation of $A \beta$ aggregates and disassembling $A \beta$ fibrils, such as the case of tetracycline [321], methyl caffeate [322], retinol [171] and gou teng [323]. Also, other products demonstrated to be able to promote $A \beta$ clearance, including withanolide $A$ [242] and retinal [171].

The reduction of $A \beta$ levels can occur through changes in the structure of $A \beta$ aggregates induced by natural compounds such as piceatannol [324]. This product is also able to decrease A $\beta$ levels through the activation of $\alpha$-secretase. Withanolide A also promotes $\alpha$-secretase expression and simultaneously inhibits $\beta$-secretase activity [242]. Other products proved to be inhibitors of $\beta$-secretase activity such as bastadin 9 [325], dictyodendrin [326], epicatechin gallate [327], gracilin [328], ianthellidone F [329], lamellarin O [329], neocoylin [330], tasiamide B [331], topsentinol K trisulfate [332] and xestosaprol [333].

Besides these mechanisms, natural compounds can prevent AD progression by other mechanisms. For example, yessotoxin [334], gambierol [335], gracilin [328], gymnodimine [336], palinurin [337] and schisandrone [338] reduced tau hyperphosphorylation. In addition, some compounds revealed to be able to suppress the oxidative stress by the scavenging of ROS and inflammatory response induced by A $\beta$, such as schisandrone [294], piceatannol [339], gracilin [340], sophocarpidine [294] and tetrahydroaplysulphurin-1 [340].

Despite the verified good outcomes, the study of some of these compounds was abandoned. For example, tetracycline was studied in 2001 but no more studies were reported for this compound. Also, for epicatechin gallate no studies were reported since 2003, and for retinal and retinol since 2004.

\section{Discussion}

Several bioactive compounds and natural extracts that were described herein to treat and prevent $\mathrm{AD}$ were revised and discussed. Until this date, most of the studied natural compounds are mainly derived from vegetable sources, with just a few molecules isolated from animals and marine organisms. Since AD is a multifactorial disorder, different therapeutic mechanisms were associated with these natural compounds.

The approval process for a new compound to become clinically available is an extremely lengthy process, and it is divided into different phases. Before tests on humans, new compounds must be evaluated in preclinical studies. Several natural compounds proved to be promising for AD therapy in in vitro and in vivo studies, as discussed in this work. However, due to physiological differences between tested animals and humans, clinical trials are still necessary to validate the safety and efficacy of these compounds. Clinical studies are of outmost importance for the development of new therapeutic compounds, drugs and devices. Human studies allow to assess safety, tolerance and effective therapeutic doses for treating diseases. Some of the performed clinical trials described in this review did not show significant improvement in the delay or treatment of the symptoms. However, even if the trials do not exhibit positive outcomes, the obtained results can be still used to guide the 
scientists in the right path for drug discovery. Also, some of the conducted clinical trials with natural compounds for AD therapy, showed no conclusive results due to the limited size of samples. However, several compounds proved to be safe in human studies and were allowed to proceed to subsequent phases. To this date, homotaurine is the only compound that reached phase III of clinical trials for AD therapy.

Despite only a few natural products having been studied in clinical trials, numerous compounds proved to have beneficial properties in preclinical studies, as shown in Figure 11. Based on the works mentioned in this review, $21 \%$ of natural compounds achieved the clinical trials phase. However, it needs to be taken into account that since these types of products are commonly consumed in the daily life, it is easier to reach the phase I of clinical trials as they are supposed to be safe for humans. Unfortunately, not all these natural products demonstrated significant effects in the AD treatment. However, they could be used for AD prevention. In the next few years, it is expected that the number of natural compounds being studied in clinical trials for the prevention and treatment of AD will significantly increase. Since the enrichment of several food and beverages is a recent trend, fortification strategies using natural products could be a promising approach for AD prevention. In fact, some groups have studied the combination of different natural compounds. In 2009, a group started clinical trials for a beverage with supplementation of a mixture of natural compounds to be consumed by AD patients [341]. This supplement, commercially called Souvenaid ${ }^{\circledR}$, demonstrates beneficial effects in the patients. This product is already commercially available in some countries being partially financially supported by the public health care systems.

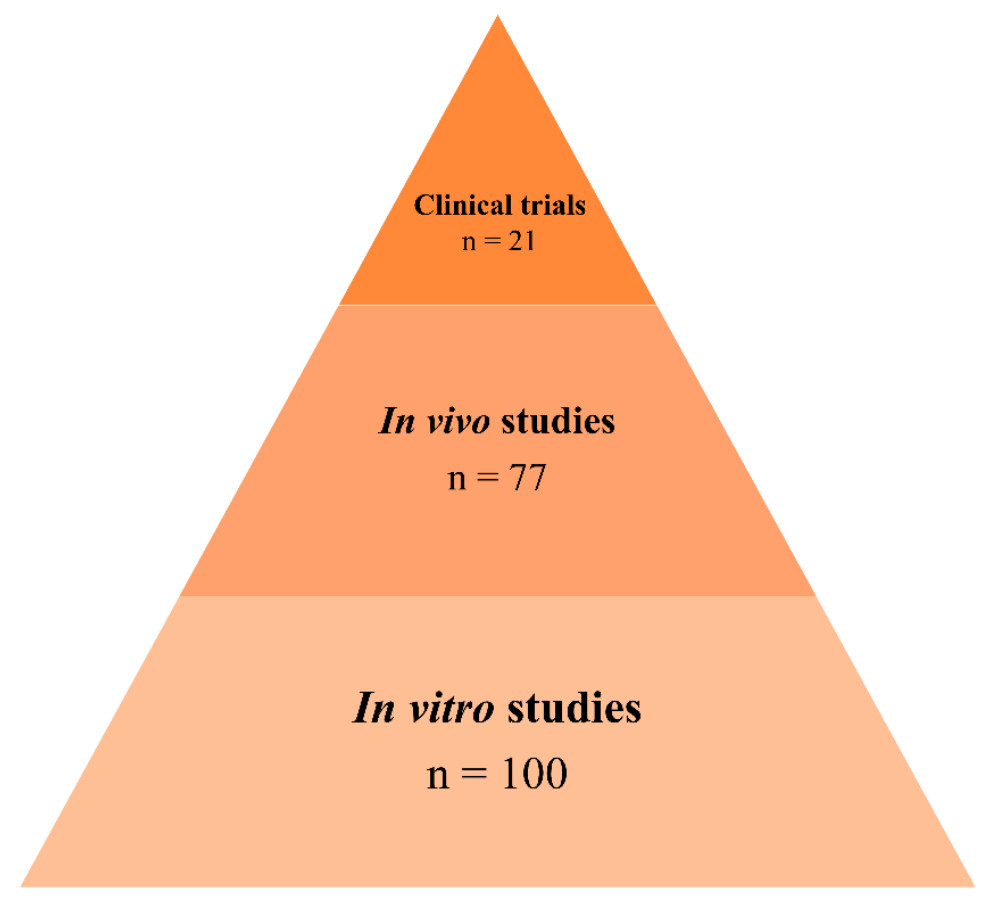

Figure 11. Number of natural products studied in different development phases.

Still, the neuroprotective effects of natural compounds depend of their ability to cross BBB. The low bioavailability of drugs and the difficulty to cross the BBB remains the major obstacles for the development of new therapies [342]. Drug delivery systems (DDS) targeting the brain seem to be a promising strategy to increase the bioavailability of compounds and the transport across the BBB [343]. DDS can protect the natural compounds from biological degradation and transport the molecules to the brain by masking their limiting physicochemical properties [344]. Thus, low doses of natural compounds are slowly released in the brain, increasing the efficiency of the therapeutic effects. 
Among the studied natural compounds, only a small percentage have been encapsulated in DDS for brain targeting. Only the encapsulation of curcumin [345-348], epigallocatechin gallate [349,350], grape extracts [312], huperzine A [351], piperine [352], quercetin [353] and resveratrol [312] in functionalized DDS was reported in the literature. Therefore, some of these compounds seem to be the most promising for the AD treatment. One interesting approach could be the co-encapsulation in the same DDS of more than one natural compound with different therapeutic mechanisms, obtaining a synergistic effect. In the future, in addition to being necessary further studies to understand how natural compounds exert their therapeutic effects on $\mathrm{AD}$, further experiments to target the drugs to the brain need to be performed.

\section{Conclusions}

$\mathrm{AD}$ is a disabling disorder with a major negative impact on our current society. At this moment, no drugs have been developed to prevent or treat AD. The existing molecules only aim to control the symptoms. With the increase of average life expectancy, it is fundamental to discover and develop new molecules able to prevent and treat $\mathrm{AD}$. Several natural products have proven to be promising for AD therapy in clinical and preclinical studies. Clinical trials have shown that several compounds appear to be effective for AD therapy, whereas others have failed in human trials. Natural compounds in earlier phases of research need further studies to uncover their therapeutic potential for AD.

Author Contributions: S.A. did the bibliographic research and wrote the manuscript. M.J.R., J.A.L. and M.d.C.P. contributed with the paper organization, writing and discussion.

Funding: This work was financially supported by: project UID/EQU/00511/2019_Laboratory for Process Engineering, Environment, Biotechnology and Energy - LEPABE funded by national funds through FCT/MCTES (PIDDAC); Project POCI-01-0145-FEDER-006939, funded by FEDER funds through COMPETE2020-Programa Operacional Competitividade e Internacionalização (POCI) and by national funds (PIDDAC) through FCT/MCTES; Project “LEPABE-2-ECO-INNOVATION"-NORTE-01-0145-FEDER-000005, funded by Norte Portugal Regional Operational Program (NORTE 2020), under PORTUGAL 2020 Partnership Agreement, through the European Regional Development Fund (ERDF), and FCT doctoral grant-SFRH/BD/129312/2017.

Conflicts of Interest: The authors declare no conflict of interest. The funders had no role in the design of the study; in the collection, analyses, or interpretation of data; in the writing of the manuscript, or in the decision to publish the results.

\section{Abbreviations}

$\begin{array}{ll}\text { A } \beta & \beta \text {-amyloid } \\ \text { ACH } & \text { Amyloid cascade hypothesis } \\ \text { AD } & \text { Alzheimer's disease } \\ \text { APP } & \text { Amyloid precursor protein } \\ \text { BBB } & \text { Blood-brain barrier } \\ \text { DDS } & \text { Drug delivery systems } \\ \text { DHA } & \text { Docosahexanoic acid } \\ \text { EGCG } & \text { Epigallocatechin gallate } \\ \text { NDGA } & \text { Nordihydroguaiaretic acid } \\ \text { NFTs } & \text { Neurofibrillary tangles } \\ \text { PGG } & 1,2,3,4,6 \text {-Penta-O-galloyl- } \beta \text {-D-glucopyranose } \\ \text { ROS } & \text { Reactive oxygen species }\end{array}$

\section{References}

1. Reitz, C.; Mayeux, R. Alzheimer disease: Epidemiology, diagnostic criteria, risk factors and biomarkers. Biochem. Pharmacol. 2014, 88, 640-651. [CrossRef]

2. Kumar, A.; Singh, A.; Ekavali. A review on Alzheimer's disease pathophysiology and its management: An update. Pharmacol. Rep. 2015, 67, 195-203. [CrossRef] 
3. Solomon, A.; Mangialasche, F.; Richard, E.; Andrieu, S.; Bennett, D.A.; Breteler, M.; Fratiglioni, L.; Hooshmand, B.; Khachaturian, A.S.; Schneider, L.S.; et al. Advances in the prevention of Alzheimer's disease and dementia. J. Int. Med. 2014, 275, 229-250. [CrossRef]

4. Selkoe, D.J.; Hardy, J. The amyloid hypothesis of Alzheimer's disease at 25 years. EMBO Mol. Med. 2016, 8 , 595-608. [CrossRef]

5. Dawkins, E.; Small, D.H. Insights into the physiological function of the $\beta$-amyloid precursor protein: Beyond Alzheimer's disease. J. Neurochem. 2014, 129, 756-769. [CrossRef] [PubMed]

6. Zhang, Z.; Song, M.; Liu, X.; Su Kang, S.; Duong, D.M.; Seyfried, N.T.; Cao, X.; Cheng, L.; Sun, Y.E.; Ping $\mathrm{Yu}, \mathrm{S}$.; et al. Delta-secretase cleaves amyloid precursor protein and regulates the pathogenesis in Alzheimer's disease. Nat. Commun. 2015, 6, 8762. [CrossRef]

7. Mohamed, T.; Shakeri, A.; Rao, P.P.N. Amyloid cascade in Alzheimer's disease: Recent advances in medicinal chemistry. Eur. J. Med. Chem. 2016, 113, 258-272. [CrossRef] [PubMed]

8. Sengupta, U.; Nilson, A.N.; Kayed, R. The Role of Amyloid- $\beta$ Oligomers in Toxicity, Propagation, and Immunotherapy. EBioMedicine 2016, 6, 42-49. [CrossRef] [PubMed]

9. Verma, M.; Vats, A.; Taneja, V. Toxic species in amyloid disorders: Oligomers or mature fibrils. Ann. Indian Acad. Neurol. 2015, 18, 138-145.

10. Swerdlow, R.H.; Burns, J.M.; Khan, S.M. The Alzheimer's disease mitochondrial cascade hypothesis: Progress and perspectives. Biochim. Biophys. Acta (BBA) Mol. Basis Dis. 2014, 1842, 1219-1231. [CrossRef]

11. Barage, S.H.; Sonawane, K.D. Amyloid cascade hypothesis: Pathogenesis and therapeutic strategies in Alzheimer's disease. Neuropeptides 2015, 52, 1-18. [CrossRef] [PubMed]

12. Heneka, M.T.; Carson, M.J.; Khoury, J.E.; Landreth, G.E.; Brosseron, F.; Feinstein, D.L.; Jacobs, A.H.; Wyss-Coray, T.; Vitorica, J.; Ransohoff, R.M.; et al. Neuroinflammation in Alzheimer's disease. Lancet Neurol. 2015, 14, 388-405. [CrossRef]

13. Huang, W.J.; Zhang, X.; Chen, W.W. Role of oxidative stress in Alzheimer's disease. Biomed. Rep. 2016, 4, 519-522. [CrossRef] [PubMed]

14. Karch, C.M.; Cruchaga, C.; Goate, Alison M. Alzheimer's Disease Genetics: From the Bench to the Clinic. Neuron 2014, 83, 11-26. [CrossRef]

15. Chin-Chan, M.; Navarro-Yepes, J.; Quintanilla-Vega, B. Environmental pollutants as risk factors for neurodegenerative disorders: Alzheimer and Parkinson diseases. Front. Cell. Neurosci. 2015, 9, 124. [CrossRef]

16. Karch, C.M.; Goate, A.M. Alzheimer's Disease Risk Genes and Mechanisms of Disease Pathogenesis. Biol. Psychiatry 2015, 77, 43-51. [CrossRef] [PubMed]

17. Barbara, G.; Joana, A.L.; Manuel, A.N.C.; Maria do Carmo, P. The Potential Effect of Fluorinated Compounds in the Treatment of Alzheimer's Disease. Curr. Pharm. Des. 2015, 21, 5725-5735.

18. Loureiro, J.A.; Crespo, R.; Börner, H.; Martins, P.M.; Rocha, F.A.; Coelho, M.; Pereira, M.C.; Rocha, S. Fluorinated beta-sheet breaker peptides. J. Mater. Chem. B 2014, 2, 2259-2264. [CrossRef]

19. Folch, J.; Petrov, D.; Ettcheto, M.; Abad, S.; Sánchez-López, E.; García, M.L.; Olloquequi, J.; Beas-Zarate, C.; Auladell, C.; Camins, A. Current Research Therapeutic Strategies for Alzheimer's Disease Treatment. Neural Plast. 2016, 2016, 15. [CrossRef] [PubMed]

20. Loureiro, J.A.; Gomes, B.; Fricker, G.; Coelho, M.A.N.; Rocha, S.; Pereira, M.C. Cellular uptake of PLGA nanoparticles targeted with anti-amyloid and anti-transferrin receptor antibodies for Alzheimer's disease treatment. Colloids Surf. B Biointerfaces 2016, 145, 8-13. [CrossRef] [PubMed]

21. Loureiro, J.A.; Gomes, B.; Fricker, G.; Cardoso, I.; Ribeiro, C.A.; Gaiteiro, C.; Coelho, M.A.N.; Pereira, M.D.C.; Rocha, S. Dual ligand immunoliposomes for drug delivery to the brain. Colloids Surf. B Biointerfaces 2015, 134, 213-219. [CrossRef]

22. Loureiro, J.A.; Gomes, B.; Coelho, M.A.; do Carmo Pereira, M.; Rocha, S. Targeting nanoparticles across the blood-brain barrier with monoclonal antibodies. Nanomedicine (Lond.) 2014, 9, 709-722. [CrossRef]

23. Silva, T.; Reis, J.; Teixeira, J.; Borges, F. Alzheimer's disease, enzyme targets and drug discovery struggles: From natural products to drug prototypes. Ageing Res. Rev. 2014, 15, 116-145. [CrossRef]

24. Dey, A.; Bhattacharya, R.; Mukherjee, A.; Pandey, D.K. Natural products against Alzheimer's disease: Pharmaco-therapeutics and biotechnological interventions. Biotechnol. Adv. 2017, 35, 178-216. [CrossRef]

25. David, B.; Wolfender, J.-L.; Dias, D.A. The pharmaceutical industry and natural products: Historical status and new trends. Phytochem. Rev. 2015, 14, 299-315. [CrossRef] 
26. Asha, H. A Review: Natural Compounds as Anti-Alzheimer's Disease Agents. Curr. Nutr. Food Sci. 2017, 13, 247-254.

27. Rasool, M.; Malik, A.; Qureshi, M.S.; Manan, A.; Pushparaj, P.N.; Asif, M.; Qazi, M.H.; Qazi, A.M.; Kamal, M.A.; Gan, S.H.; et al. Recent Updates in the Treatment of Neurodegenerative Disorders Using Natural Compounds. Evid. Based Complement. Altern. Med. 2014, 2014, 979730. [CrossRef]

28. Andrade, S.; Ramalho, M.J.; Loureiro, J.A.; Pereira, M.C. Interaction of natural compounds with biomembrane models: A biophysical approach for the Alzheimer's disease therapy. Colloids Surf. B Biointerfaces 2019, 180, 83-92. [CrossRef]

29. Butler, M.S.; Robertson, A.A.; Cooper, M.A. Natural product and natural product derived drugs in clinical trials. Nat. Prod. Rep. 2014, 31, 1612-1661. [CrossRef]

30. Doig, A.J.; Derreumaux, P. Inhibition of protein aggregation and amyloid formation by small molecules. Curr. Opin. Struct. Biol. 2015, 30, 50-56. [CrossRef]

31. Baranello, R.J.; Bharani, K.L.; Padmaraju, V.; Chopra, N.K.; Lahiri, D.H.; Greig, N.A.; Pappolla, M.; Sambamurti, K. Amyloid-Beta Protein Clearance and Degradation (ABCD) Pathways and their Role in Alzheimer's Disease. Curr. Alzheimer Res. 2015, 12, 32-46. [CrossRef]

32. Wischik, C.M.; Harrington, C.R.; Storey, J.M.D. Tau-aggregation inhibitor therapy for Alzheimer's disease. Biochem. Pharmacol. 2014, 88, 529-539. [CrossRef]

33. Morales, I.; Guzmán-Martínez, L.; Cerda-Troncoso, C.; Farías, G.A.; Maccioni, R.B. Neuroinflammation in the pathogenesis of Alzheimer's disease. A rational framework for the search of novel therapeutic approaches. Front. Cell. Neurosci. 2014, 8, 112. [CrossRef]

34. Ahmed, T.; Javed, S.; Javed, S.; Tariq, A.; Šamec, D.; Tejada, S.; Nabavi, S.F.; Braidy, N.; Nabavi, S.M. Resveratrol and Alzheimer's Disease: Mechanistic Insights. Mol. Neurobiol. 2017, 54, 2622-2635. [CrossRef]

35. Miller, B.J.; Whisner, C.M.; Johnston, C.S. Vitamin D Supplementation Appears to Increase Plasma A $\beta 40$ in Vitamin D Insufficient Older Adults: A Pilot Randomized Controlled Trial. J. Alzheimer's Dis. 2016, 52, 843-847. [CrossRef]

36. SanMartín, C.D.; Henriquez, M.; Chacon, C.; Ponce, D.P.; Salech, F.; Rogers, N.K.; Behrens, M.I. Vitamin D Increases A $\beta 140$ Plasma Levels and Protects Lymphocytes from Oxidative Death in Mild Cognitive Impairment Patients. Curr. Alzheimer Res. 2018, 15, 561-569. [CrossRef]

37. Annweiler, C.; Herrmann, F.R.; Fantino, B.; Brugg, B.; Beauchet, O. Effectiveness of the Combination of Memantine Plus Vitamin D on Cognition in Patients With Alzheimer Disease: A Pre-Post Pilot Study. Cogn. Behav. Neurol. 2012, 25, 121-127. [CrossRef]

38. Galasko, D.R.; Peskind, E.; Clark, C.M.; et al. Antioxidants for alzheimer disease: A randomized clinical trial with cerebrospinal fluid biomarker measures. Arch. Neurol. 2012, 69, 836-841. [CrossRef]

39. Kontush, A.; Mann, U.; Arlt, S.; Ujeyl, A.; Lührs, C.; Müller-Thomsen, T.; Beisiegel, U. Influence of vitamin E and $\mathrm{C}$ supplementation on lipoprotein oxidation in patients with Alzheimer's disease. Free Radic. Biol. Med. 2001, 31, 345-354. [CrossRef]

40. Sano, M.; Ernesto, C.; Thomas, R.G.; Klauber, M.R.; Schafer, K.; Grundman, M.; Woodbury, P.; Growdon, J.; Cotman, C.W.; Pfeiffer, E.; et al. A Controlled Trial of Selegiline, Alpha-Tocopherol, or Both as Treatment for Alzheimer's Disease. N. Engl. J. Med. 1997, 336, 1216-1222. [CrossRef]

41. Petersen, R.C.; Thomas, R.G.; Grundman, M.; Bennett, D.; Doody, R.; Ferris, S.; Galasko, D.; Jin, S.; Kaye, J.; Levey, A.; et al. Vitamin E and Donepezil for the Treatment of Mild Cognitive Impairment. N. Engl. J. Med. 2005, 352, 2379-2388. [CrossRef]

42. Dysken, M.W.; Sano, M.; Asthana, S.; et al. Effect of vitamin e and memantine on functional decline in alzheimer disease: The team-ad va cooperative randomized trial. JAMA 2014, 311, 33-44. [CrossRef] [PubMed]

43. Kryscio, R.J.; Abner, E.L.; Caban-Holt, A.; Lovell, M.; Goodman, P.; Darke, A.K.; Yee, M.; Crowley, J.; Schmitt, F.A. Association of Antioxidant Supplement Use and Dementia in the Prevention of Alzheimer's Disease by Vitamin E and Selenium Trial (PREADViSE). JAMA Neurol. 2017, 74, 567-573. [CrossRef]

44. Freund-Levi, Y.; Eriksdotter-Jönhagen, M.; Cederholm, T.; Basun, H.; Faxén-Irving, G.; Garlind, A.; Vedin, I.; Vessby, B.; Wahlund, L.-O.; Palmblad, J. w-3 Fatty Acid Treatment in 174 Patients With Mild to Moderate Alzheimer Disease: OmegAD Study: A Randomized Double-blind Trial. Arch. Neurol. 2006, 63, 1402-1408. [CrossRef] [PubMed] 
45. Quinn, J.F.; Raman, R.; Thomas, R.G.; Yurko-Mauro, K.; Nelson, E.B.; Van Dyck, C.; Galvin, J.E.; Emond, J.; Jack, C.R.; Weiner, M.; et al. Docosahexaenoic Acid Supplementation and Cognitive Decline in Alzheimer Disease: A Randomized Trial. JAMA 2010, 304, 1903-1911. [CrossRef]

46. Yurko-Mauro, K.; McCarthy, D.; Rom, D.; Nelson, E.B.; Ryan, A.S.; Blackwell, A.; Salem, N.; Stedman, M. Beneficial effects of docosahexaenoic acid on cognition in age-related cognitive decline. Alzheimer's Dement. 2010, 6, 456-464. [CrossRef] [PubMed]

47. Lee, L.K.; Shahar, S.; Chin, A.-V.; Yusoff, N.A.M. Docosahexaenoic acid-concentrated fish oil supplementation in subjects with mild cognitive impairment (MCI): A 12-month randomised, double-blind, placebo-controlled trial. Psychopharmacology 2013, 225, 605-612. [CrossRef] [PubMed]

48. Gauthier, S.; Aisen, P.S.; Ferris, S.H.; Saumier, D.; Duong, A.; Haine, D.; Garceau, D.; Suhy, J.; Oh, J.; Lau, W.; et al. Effect of tramiprosate in patients with mild-to-moderate alzheimer's disease: Exploratory analyses of the MRI sub-group of the alphase study. JNHA J. Nutr. Health Aging 2009, 13, 550-557. [CrossRef]

49. Aisen, P.S.; Gauthier, S.; Ferris, S.H.; Saumier, D.; Haine, D.; Garceau, D.; Duong, A.; Suhy, J.; Oh, J.; Lau, W.C.; et al. Tramiprosate in mild-to-moderate Alzheimer's disease-A randomized, double-blind, placebo-controlled, multi-centre study (the Alphase Study). Arch. Med. Sci. AMS 2011, 7, 102-111. [CrossRef] [PubMed]

50. Aisen, P.S.; Saumier, D.; Briand, R.; Laurin, J.; Gervais, F.; Tremblay, P.; Garceau, D. A Phase II study targeting amyloid- $\beta$ with 3APS in mild-to-moderate Alzheimer disease. Neurology 2006, 67, 1757-1763. [CrossRef]

51. Martorana, A.; Di Lorenzo, F.; Manenti, G.; Semprini, R.; Koch, G. Homotaurine Induces Measurable Changes of Short Latency Afferent Inhibition in a Group of Mild Cognitive Impairment Individuals. Front. Aging Neurosci. 2014, 6, 254. [CrossRef]

52. Xu, S.S.; Gao, Z.X.; Weng, Z.; Du, Z.M.; Xu, W.A.; Yang, J.S.; Zhang, M.L.; Tong, Z.H.; Fang, Y.S.; Chai, X.S. Efficacy of tablet huperzine-A on memory, cognition, and behavior in Alzheimer's disease. Zhongguo Yao Li Хие Вао 1995, 16, 391-395.

53. Xu, S.S.; Cai, Z.Y.; Qu, Z.W.; Yang, R.M.; Cai, Y.L.; Wang, G.Q.; Su, X.Q.; Zhong, X.S.; Cheng, R.Y.; Xu, W.A.; et al. Huperzine-A in capsules and tablets for treating patients with Alzheimer disease. Zhongguo Yao Li Хие Вао 1999, 20, 486-490.

54. Rafii, M.S.; Walsh, S.; Little, J.T.; Behan, K.; Reynolds, B.; Ward, C.; Jin, S.; Thomas, R.; Aisen, P.S. A phase II trial of huperzine A in mild to moderate Alzheimer disease. Neurology 2011, 76, 1389-1394. [CrossRef]

55. Nelson, T.J.; Sun, M.K.; Lim, C.; Sen, A.; Khan, T.; Chirila, F.V.; Alkon, D.L. Bryostatin Effects on Cognitive Function and PKCvarepsilon in Alzheimer's Disease Phase IIa and Expanded Access Trials. J. Alzheimers Dis. 2017, 58, 521-535. [CrossRef]

56. Farlow, M.R.; Thompson, R.E.; Wei, L.J.; Tuchman, A.J.; Grenier, E.; Crockford, D.; Wilke, S.; Benison, J.; Alkon, D.L. A Randomized, Double-Blind, Placebo-Controlled, Phase II Study Assessing Safety, Tolerability, and Efficacy of Bryostatin in the Treatment of Moderately Severe to Severe Alzheimer's Disease. J. Alzheimers Dis. 2018. [CrossRef]

57. Brusco, L.I.; Márquez, M.; Cardinali, D.P. Monozygotic twins with Alzheimer's disease treated with melatonin: Case report. J. Pineal Res. 1998, 25, 260-263. [CrossRef]

58. Brusco, L.I.; Marquez, M.; Cardinali, D.P. Melatonin treatment stabilizes chronobiologic and cognitive symptoms in Alzheimer's disease. Neuro Endocrinol. Lett. 2000, 21, 39-42.

59. Furio, A.M.; Brusco, L.I.; Cardinali, D.P. Possible therapeutic value of melatonin in mild cognitive impairment: A retrospective study. J. Pineal Res. 2007, 43, 404-409. [CrossRef]

60. Wade, A.G.; Farmer, M.; Harari, G.; Fund, N.; Laudon, M.; Nir, T.; Frydman-Marom, A.; Zisapel, N. Add-on prolonged-release melatonin for cognitive function and sleep in mild to moderate Alzheimer's disease: A 6-month, randomized, placebo-controlled, multicenter trial. Clin. Interv. Aging 2014, 9, 947-961.

61. Turner, R.S.; Thomas, R.G.; Craft, S.; van Dyck, C.H.; Mintzer, J.; Reynolds, B.A.; Brewer, J.B.; Rissman, R.A.; Raman, R.; Aisen, P.S.; et al. A randomized, double-blind, placebo-controlled trial of resveratrol for Alzheimer disease. Neurology 2015, 85, 1383-1391. [CrossRef]

62. Zhu, C.W.; Grossman, H.; Neugroschl, J.; Parker, S.; Burden, A.; Luo, X.; Sano, M. A randomized, double-blind, placebo-controlled trial of resveratrol with glucose and malate (RGM) to slow the progression of Alzheimer's disease: A pilot study. Alzheimer's Dement. Transl. Res. Clin. Interv. 2018, 4, 609-616. [CrossRef] 
63. Jones, G.M.; Sahakian, B.J.; Levy, R.; Warburton, D.M.; Gray, J.A. Effects of acute subcutaneous nicotine on attention, information processing and short-term memory in Alzheimer's disease. Psychopharmacol 1992, 108, 485-494. [CrossRef]

64. Wilson, A.L.; Langley, L.K.; Monley, J.; Bauer, T.; Rottunda, S.; McFalls, E.; Kovera, C.; McCarten, J.R. Nicotine patches in Alzheimer's disease: Pilot study on learning, memory, and safety. Pharmacol. Biochem. Behav. 1995, 51, 509-514. [CrossRef]

65. White, H.K.; Levin, E.D. Four-week nicotine skin patch treatment effects on cognitive performance in Alzheimer's disease. Psychopharmacology (Berl) 1999, 143, 158-165. [CrossRef]

66. Baum, L.; Lam, C.W.K.; Cheung, S.K.-K.; Kwok, T.; Lui, V.; Tsoh, J.; Lam, L.; Leung, V.; Hui, E.; Ng, C.; et al. Six-Month Randomized, Placebo-Controlled, Double-Blind, Pilot Clinical Trial of Curcumin in Patients With Alzheimer Disease. J. Clin. Psychopharmacol. 2008, 28, 110-113. [CrossRef]

67. Bachinskaya, N.; Hoerr, R.; Ihl, R. Alleviating neuropsychiatric symptoms in dementia: The effects of Ginkgo biloba extract EGb 761. Findings from a randomized controlled trial. Neuropsychiatr. Dis. Treat. 2011, 7, 209-215.

68. Ihl, R.; Bachinskaya, N.; Korczyn, A.D.; Vakhapova, V.; Tribanek, M.; Hoerr, R.; Napryeyenko, O.; Group, G.S. Efficacy and safety of a once-daily formulation of Ginkgo biloba extract EGb 761 in dementia with neuropsychiatric features: A randomized controlled trial. Int. J. Geriatr. Psychiatry 2011, 26, 1186-1194. [CrossRef]

69. Herrschaft, H.; Nacu, A.; Likhachev, S.; Sholomov, I.; Hoerr, R.; Schlaefke, S. Ginkgo biloba extract EGb 761®in dementia with neuropsychiatric features: A randomised, placebo-controlled trial to confirm the efficacy and safety of a daily dose of $240 \mathrm{mg}$. J. Psychiatr. Res. 2012, 46, 716-723. [CrossRef]

70. Ihl, R.; Tribanek, M.; Bachinskaya, N.; for the, G.S.G. Efficacy and Tolerability of a Once Daily Formulation of Ginkgo biloba Extract EGb 761®in Alzheimer's Disease and Vascular Dementia: Results from a Randomised Controlled Trial. Pharmacopsychiatry 2012, 45, 41-46. [CrossRef]

71. Gavrilova, S.I.; Preuss, U.W.; Wong, J.W.M.; Hoerr, R.; Kaschel, R.; Bachinskaya, N. Efficacy and safety of Ginkgo biloba extract EGb 761@in mild cognitive impairment with neuropsychiatric symptoms: A randomized, placebo-controlled, double-blind, multi-center trial. Int. J. Geriatr. Psychiatry 2014, 29, 1087-1095. [CrossRef] [PubMed]

72. Akhondzadeh, S.; Shafiee Sabet, M.; Harirchian, M.H.; Togha, M.; Cheraghmakani, H.; Razeghi, S.; Hejazi, S.S.; Yousefi, M.H.; Alimardani, R.; Jamshidi, A.; et al. A 22-week, multicenter, randomized, double-blind controlled trial of Crocus sativus in the treatment of mild-to-moderate Alzheimer's disease. Psychopharmacology 2010, 207, 637-643. [CrossRef] [PubMed]

73. Akhondzadeh, S.; Noroozian, M.; Mohammadi, M.; Ohadinia, S.; Jamshidi, A.; Khani, M. Melissa officinalis extract in the treatment of patients with mild to moderate Alzheimer's disease: A double blind, randomised, placebo controlled trial. J. Neurol. Neurosurg. Psychiatry 2003, 74, 863-866. [CrossRef] [PubMed]

74. Arab, H.; Mahjoub, S.; Hajian-Tilaki, K.; Moghadasi, M. The effect of green tea consumption on oxidative stress markers and cognitive function in patients with Alzheimer's disease: A prospective intervention study. CASP J. Int. Med. 2016, 7, 188-194.

75. Barbagallo, M.; Marotta, F.; Dominguez, L.J. Oxidative stress in patients with Alzheimer's disease: Effect of extracts of fermented papaya powder. Mediat. Inflamm. 2015. [CrossRef] [PubMed]

76. Scholey, A.B.; Tildesley, N.T.; Ballard, C.G.; Wesnes, K.A.; Tasker, A.; Perry, E.K.; Kennedy, D.O. An extract of Salvia (sage) with anticholinesterase properties improves memory and attention in healthy older volunteers. Psychopharmacology (Berl) 2008, 198, 127-139. [CrossRef]

77. De la Rubia Orti, J.E.; Garcia-Pardo, M.P.; Drehmer, E.; Sancho Cantus, D.; Julian Rochina, M.; Aguilar, M.A.; Hu Yang, I. Improvement of Main Cognitive Functions in Patients with Alzheimer's Disease after Treatment with Coconut Oil Enriched Mediterranean Diet: A Pilot Study. J. Alzheimers Dis. 2018, 65, 577-587. [CrossRef]

78. Remington, R.; Chan, A.; Lepore, A.; Kotlya, E.; Shea, T.B. Apple juice improved behavioral but not cognitive symptoms in moderate-to-late stage Alzheimer's disease in an open-label pilot study. Am. J. Alzheimers Dis. Dement. 2010, 25, 367-371. [CrossRef]

79. Krikorian, R.; Shidler, M.D.; Nash, T.A.; Kalt, W.; Vinqvist-Tymchuk, M.R.; Shukitt-Hale, B.; Joseph, J.A. Blueberry supplementation improves memory in older adults. J. Agric. Food Chem. 2010, 58, 3996-4000. [CrossRef] 
80. Szaniszlo, P.; German, P.; Hajas, G.; Saenz, D.N.; Kruzel, M.; Boldogh, I. New insights into clinical trial for Colostrinin in Alzheimer's disease. J. Nutr. Health Aging 2009, 13, 235-241. [CrossRef]

81. Ahmad, A.A.; Shah, S.; Badshah, H.J.; Kim, M.; Ali, T.H.; Yoon, G.H.; Kim, T.B.; Abid, N.; Ur Rehman, S.; Khan, S.O.; et al. Neuroprotection by vitamin $\mathrm{C}$ against ethanol -induced neuroinflammation associated neurodegeneration in developing rat brain. CNS Neurol. Disord. Drug Targets 2016, 15, 360-370. [CrossRef]

82. Sil, S.; Ghosh, T.; Gupta, P.; Ghosh, R.; Kabir, S.N.; Roy, A. Dual Role of Vitamin C on the Neuroinflammation Mediated Neurodegeneration and Memory Impairments in Colchicine Induced Rat Model of Alzheimer Disease. J. Mol. Neurosci. 2016, 60, 421-435. [CrossRef]

83. Murakami, K.; Murata, N.; Ozawa, Y.; Kinoshita, N.; Irie, K.; Shirasawa, T.; Shimizu, T. Vitamin C restores behavioral deficits and amyloid-beta oligomerization without affecting plaque formation in a mouse model of Alzheimer's disease. J. Alzheimers Dis. 2011, 26, 7-18. [CrossRef]

84. Kook, S.Y.; Lee, K.M.; Kim, Y.; Cha, M.Y.; Kang, S.; Baik, S.H.; Lee, H.; Park, R.; Mook-Jung, I. High-dose of vitamin $C$ supplementation reduces amyloid plaque burden and ameliorates pathological changes in the brain of 5XFAD mice. Cell Death Dis. 2014, 5, e1083. [CrossRef]

85. Rosales-Corral, S.; Tan, D.X.; Reiter, R.J.; Valdivia-Velazquez, M.; Martinez-Barboza, G.; Acosta-Martinez, J.P.; Ortiz, G.G. Orally administered melatonin reduces oxidative stress and proinflammatory cytokines induced by amyloid-beta peptide in rat brain: A comparative, in vivo study versus vitamin C and E. J. Pineal Res. 2003, 35, 80-84. [CrossRef]

86. Sung, S.; Yao, Y.; Uryu, K.; Yang, H.; Lee, V.M.; Trojanowski, J.Q.; Pratico, D. Early vitamin E supplementation in young but not aged mice reduces Abeta levels and amyloid deposition in a transgenic model of Alzheimer's disease. FASEB J. 2004, 18, 323-325.

87. Ramalho, M.J.; Loureiro, J.A.; Gomes, B.; Frasco, M.F.; Coelho, M.A.N.; Pereira, M.C. PLGA nanoparticles for calcitriol delivery. In Proceedings of the 2015 IEEE 4th Portuguese Meeting on Bioengineering, ENBENG, Porto, Portugal, 26-28 Februray 2015.

88. Ramalho, M.J.; Loureiro, J.A.; Gomes, B.; Frasco, M.F.; Coelho, M.A.N.; Pereira, M.C. PLGA nanoparticles as a platform for vitamin D-based cancer therapy. Beilstein J. Nanotechnol. 2015, 6, 1306-1318. [CrossRef]

89. Ramalho, M.J.; Coelho, M.A.N.; Pereira, M.C. Nanoparticles for Delivery of Vitamin D: Challenges and Opportunities. In A Critical Evaluation of Vitamin D-Clinical Overview; Gowder, S., Ed.; InTech: Rijeka, Croatia, 2017; p. 11.

90. Yu, J.; Gattoni-Celli, M.; Zhu, H.; Bhat, N.R.; Sambamurti, K.; Gattoni-Celli, S.; Kindy, M.S. Vitamin D3-enriched diet correlates with a decrease of amyloid plaques in the brain of AbetaPP transgenic mice. J. Alzheimers Dis. 2011, 25, 295-307. [CrossRef]

91. Grimm, M.; Thiel, A.; Lauer, A.; Winkler, J.; Lehmann, J.; Regner, L.; Nelke, C.; Janitschke, D.; Benoist, C.; Streidenberger, O.; et al. Vitamin D and Its Analogues Decrease Amyloid- $\beta$ (A $\beta$ ) Formation and Increase A $\beta$-Degradation. Int. J. Mol. Sci. 2017, 18, 2764. [CrossRef]

92. Landel, V.; Millet, P.; Baranger, K.; Loriod, B.; Féron, F. Vitamin D interacts with Esr1 and Igf1 to regulate molecular pathways relevant to Alzheimer's disease. Mol. Neurodegener. 2016, 11, 22. [CrossRef]

93. Morello, M.; Landel, V.; Lacassagne, E.; Baranger, K.; Annweiler, C.; Féron, F.; Millet, P. Vitamin D Improves Neurogenesis and Cognition in a Mouse Model of Alzheimer's Disease. Mol. Neurobiol. 2018, 55, 6463-6479. [CrossRef]

94. Kishi, T.; Matsunaga, S.; Oya, K.; Nomura, I.; Ikuta, T.; Iwata, N. Memantine for Alzheimer's disease: An updated systematic review and meta-analysis. J. Alzheimer's Dis. 2017, 60, 401-425. [CrossRef]

95. Youdim, M.B.H.; Edmondson, D.; Tipton, K.F. The therapeutic potential of monoamine oxidase inhibitors. Nat. Rev. Neurosci. 2006, 7, 295. [CrossRef]

96. Varikasuvu, S.R.; Prasad, V.S.; Kothapalli, J.; Manne, M. Brain Selenium in Alzheimer's Disease (BRAIN SEAD Study): A Systematic Review and Meta-Analysis. Biol. Trace Elem. Res. 2018. [CrossRef]

97. Hixson, S.M.; Sharma, B.; Kainz, M.J.; Wacker, A.; Arts, M.T. Production, distribution, and abundance of long-chain omega-3 polyunsaturated fatty acids: A fundamental dichotomy between freshwater and terrestrial ecosystems. Environ. Rev. 2015, 23, 414-424. [CrossRef]

98. Hashimoto, M.; Hossain, S.; Katakura, M.; Al Mamun, A.; Shido, O. The binding of A $\beta 1-42$ to lipid rafts of $\mathrm{RBC}$ is enhanced by dietary docosahexaenoic acid in rats: Implicates to Alzheimer's disease. Biochim. Et Biophys. Acta Biomembr. 2015, 1848, 1402-1409. [CrossRef] 
99. Lim, G.P.; Calon, F.; Morihara, T.; Yang, F.; Teter, B.; Ubeda, O.; Salem, N., Jr.; Frautschy, S.A.; Cole, G.M. A diet enriched with the omega-3 fatty acid docosahexaenoic acid reduces amyloid burden in an aged Alzheimer mouse model. J. Neurosci. 2005, 25, 3032-3040. [CrossRef]

100. Grimm, M.O.; Kuchenbecker, J.; Grosgen, S.; Burg, V.K.; Hundsdorfer, B.; Rothhaar, T.L.; Friess, P.; de Wilde, M.C.; Broersen, L.M.; Penke, B.; et al. Docosahexaenoic acid reduces amyloid beta production via multiple pleiotropic mechanisms. J. Biol. Chem. 2011, 286, 14028-14039. [CrossRef]

101. Hossain, S.; Hashimoto, M.; Katakura, M.; Miwa, K.; Shimada, T.; Shido, O. Mechanism of docosahexaenoic acid-induced inhibition of in vitro $\mathrm{A} \beta 1-42$ fibrillation and $\mathrm{A} \beta 1-42$-induced toxicity in SH-S5Y5 cells. J. Neurochem. 2009, 111, 568-579. [CrossRef]

102. Grimm, M.O.W.; Mett, J.; Stahlmann, C.P.; Haupenthal, V.J.; Blümel, T.; Stötzel, H.; Grimm, H.S.; Hartmann, T. Eicosapentaenoic acid and docosahexaenoic acid increase the degradation of amyloid- $\beta$ by affecting insulin-degrading enzyme1. Biochem. Cell Biol. 2016, 94, 534-542. [CrossRef]

103. Hashimoto, M.; Shahdat, H.M.; Yamashita, S.; Katakura, M.; Tanabe, Y.; Fujiwara, H.; Gamoh, S.; Miyazawa, T.; Arai, H.; Shimada, T.; et al. Docosahexaenoic acid disrupts in vitro amyloid $\beta 1-40$ fibrillation and concomitantly inhibits amyloid levels in cerebral cortex of Alzheimer's disease model rats. J. Neurochem. 2008, 107, 1634-1646. [CrossRef]

104. Mehdinia, A.; Rostami, S.; Dadkhah, S.; Fumani, N.S. Simultaneous screening of homotaurine and taurine in marine macro-algae using liquid chromatography-fluorescence detection. J. Iran. Chem. Soc. 2017, 14, 2135-2142. [CrossRef]

105. Santa-Maria, I.; Hernández, F.; Del Rio, J.; Moreno, F.J.; Avila, J. Tramiprosate, a drug of potential interest for the treatment of Alzheimer's disease, promotes an abnormal aggregation of tau. Mol. Neurodegener. 2007, 2, 17. [CrossRef]

106. Gervais, F.; Paquette, J.; Morissette, C.; Krzywkowski, P.; Yu, M.; Azzi, M.; Lacombe, D.; Kong, X.; Aman, A.; Laurin, J.; et al. Targeting soluble Abeta peptide with Tramiprosate for the treatment of brain amyloidosis. Neurobiol. Aging 2007, 28, 537-547. [CrossRef]

107. Kocis, P.; Tolar, M.; Yu, J.; Sinko, W.; Ray, S.; Blennow, K.; Fillit, H.; Hey, J.A. Elucidating the A $\beta 42$ Anti-Aggregation Mechanism of Action of Tramiprosate in Alzheimer's Disease: Integrating Molecular Analytical Methods, Pharmacokinetic and Clinical Data. Cns. Drugs 2017, 31, 495-509. [CrossRef]

108. Marambaud, P.; Zhao, H.; Davies, P. Resveratrol promotes clearance of Alzheimer's disease amyloid-beta peptides. J. Biol. Chem. 2005, 280, 37377-37382. [CrossRef]

109. Ladiwala, A.R.A.; Lin, J.C.; Bale, S.S.; Marcelino-Cruz, A.M.; Bhattacharya, M.; Dordick, J.S.; Tessier, P.M. Resveratrol selectively remodels soluble oligomers and fibrils of amyloid $A \beta$ into off-pathway conformers. J. Biol. Chem. 2010, 285, 24228-24237. [CrossRef]

110. Xiao, X.Q.; Zhang, H.Y.; Tang, X.C. Huperzine A attenuates amyloid beta-peptide fragment 25-35-induced apoptosis in rat cortical neurons via inhibiting reactive oxygen species formation and caspase- 3 activation. J. Neurosci. Res. 2002, 67, 30-36. [CrossRef]

111. Peng, Y.; Jiang, L.; Lee, D.Y.; Schachter, S.C.; Ma, Z.; Lemere, C.A. Effects of huperzine A on amyloid precursor protein processing and beta-amyloid generation in human embryonic kidney 293 APP Swedish mutant cells. J. Neurosci. Res. 2006, 84, 903-911. [CrossRef]

112. Tian, X.R.; Tang, H.F.; Tian, X.L.; Hu, J.J.; Huang, L.L.; Gustafson, K.R. Review of bioactive secondary metabolites from marine bryozoans in the progress of new drugs discovery. Future Med. Chem. 2018, 10, 1497-1514. [CrossRef]

113. Etcheberrigaray, R.; Tan, M.; Dewachter, I.; Kuiperi, C.; Van der Auwera, I.; Wera, S.; Qiao, L.; Bank, B.; Nelson, T.J.; Kozikowski, A.P.; et al. Therapeutic effects of PKC activators in Alzheimer's disease transgenic mice. Proc. Natl. Acad. Sci. USA 2004, 101, 11141-11146. [CrossRef]

114. Schrott, L.M.; Jackson, K.; Yi, P.; Dietz, F.; Johnson, G.S.; Basting, T.F.; Purdum, G.; Tyler, T.; Rios, J.D.; Castor, T.P.; et al. Acute Oral Bryostatin-1 Administration Improves Learning Deficits in the APP/PS1 Transgenic Mouse Model of Alzheimer's Disease. Curr. Alzheimer Res. 2015, 12, 22-31. [CrossRef]

115. Shah, S.A.; Khan, M.; Jo, M.-H.; Jo, M.G.; Amin, F.U.; Kim, M.O. Melatonin Stimulates the SIRT1/Nrf2 Signaling Pathway Counteracting Lipopolysaccharide (LPS)-Induced Oxidative Stress to Rescue Postnatal Rat Brain. CNS Neurosci. Ther. 2017, 23, 33-44. [CrossRef] 
116. Ali, T.; Badshah, H.; Kim, T.H.; Kim, M.O. Melatonin attenuates D-galactose-induced memory impairment, neuroinflammation and neurodegeneration via RAGE/NF-KB/JNK signaling pathway in aging mouse model. J. Pineal Res. 2015, 58, 71-85. [CrossRef]

117. Pappolla, M.; Bozner, P.; Soto, C.; Shao, H.; Robakis, N.K.; Zagorski, M.; Frangione, B.; Ghiso, J. Inhibition of Alzheimer beta-fibrillogenesis by melatonin. J. Biol. Chem. 1998, 273, 7185-7188. [CrossRef]

118. Rudnitskaya, E.A.; Muraleva, N.A.; Maksimova, K.Y.; Kiseleva, E.; Kolosova, N.G.; Stefanova, N.A. Melatonin Attenuates Memory Impairment, Amyloid-beta Accumulation, and Neurodegeneration in a Rat Model of Sporadic Alzheimer's Disease. J. Alzheimers Dis. 2015, 47, 103-116. [CrossRef]

119. Panmanee, J.; Nopparat, C.; Chavanich, N.; Shukla, M.; Mukda, S.; Song, W.; Vincent, B.; Govitrapong, P. Melatonin regulates the transcription of betaAPP-cleaving secretases mediated through melatonin receptors in human neuroblastoma SH-SY5Y cells. J. Pineal Res. 2015, 59, 308-320. [CrossRef]

120. Andrade, S.; Ramalho, M.J.; Pereira, M.D.C.; Loureiro, J.A. Resveratrol Brain Delivery for Neurological Disorders Prevention and Treatment. Front. Pharmacol. 2018, 9, 1261. [CrossRef]

121. Andrade, S.; Loureiro, J.A.; Coelho, M.A.N.; Pereira, M.D.C. Interaction studies of amyloid beta-peptide with the natural compound resveratrol. In Proceedings of the 2015 IEEE 4th Portuguese Meeting on Bioengineering (ENBENG), Porto, Portugal, 26-28 Februray 2015; pp. 1-3.

122. Zhao, H.F.; Li, N.; Wang, Q.; Cheng, X.J.; Li, X.M.; Liu, T.T. Resveratrol decreases the insoluble A $\beta 1-42$ level in hippocampus and protects the integrity of the blood-brain barrier in AD rats. Neuroscience 2015, 310, 641-649. [CrossRef]

123. Karuppagounder, S.S.; Pinto, J.T.; Xu, H.; Chen, H.L.; Beal, M.F.; Gibson, G.E. Dietary supplementation with resveratrol reduces plaque pathology in a transgenic model of Alzheimer's disease. Neurochem. Int. 2009, 54, 111-118. [CrossRef]

124. Ma, X.R.; Sun, Z.K.; Liu, Y.R.; Jia, Y.J.; Zhang, B.A.; Zhang, J.W. Resveratrol improves cognition and reduces oxidative stress in rats with vascular dementia. Neural Regen. Res. 2013, 8, 2050-2059.

125. He, X.; Li, Z.; Rizak, J.D.; Wu, S.; Wang, Z.; He, R.; Su, M.; Qin, D.; Wang, J.; Hu, X. Resveratrol attenuates formaldehyde induced hyperphosphorylation of tau protein and cytotoxicity in N2a cells. Front. Neurosci. 2017, 10, 598. [CrossRef]

126. Salomon, A.R.; Marcinowski, K.J.; Friedland, R.P.; Zagorski, M.G. Nicotine inhibits amyloid formation by the beta-peptide. Biochemistry 1996, 35, 13568-13578. [CrossRef]

127. Srivareerat, M.; Tran, T.T.; Salim, S.; Aleisa, A.M.; Alkadhi, K.A. Chronic nicotine restores normal A $\beta$ levels and prevents short-term memory and E-LTP impairment in A $\beta$ rat model of Alzheimer's disease. Neurobiol. Aging 2011, 32, 834-844. [CrossRef]

128. Nordberg, A.; Hellstrom-Lindahl, E.; Lee, M.; Johnson, M.; Mousavi, M.; Hall, R.; Perry, E.; Bednar, I.; Court, J. Chronic nicotine treatment reduces beta-amyloidosis in the brain of a mouse model of Alzheimer's disease (APPsw). J. Neurochem. 2002, 81, 655-658. [CrossRef]

129. Ono, K.; Hasegawa, K.; Yamada, M.; Naiki, H. Nicotine breaks down preformed Alzheimer's beta-amyloid fibrils in vitro. Biol. Psychiatry 2002, 52, 880-886. [CrossRef]

130. Navarro, E.; Buendia, I.; Parada, E.; León, R.; Jansen-Duerr, P.; Pircher, H.; Egea, J.; Lopez, M.G. Alpha7 nicotinic receptor activation protects against oxidative stress via heme-oxygenase I induction. Biochem. Pharmacol. 2015, 97, 473-481. [CrossRef]

131. Lahiri, D.K.; Utsuki, T.; Chen, D.; Farlow, M.R.; Shoaib, M.; Ingram, D.K.; Greig, N.H. Nicotine reduces the secretion of Alzheimer's $\beta$-amyloid precursor protein containing $\beta$-amyloid peptide in the rat without altering synaptic proteins. Ann. N. Y. Acad. Sci. 2002, 965, 364-372. [CrossRef]

132. Yang, F.; Lim, G.P.; Begum, A.N.; Ubeda, O.J.; Simmons, M.R.; Ambegaokar, S.S.; Chen, P.P.; Kayed, R.; Glabe, C.G.; Frautschy, S.A.; et al. Curcumin inhibits formation of amyloid beta oligomers and fibrils, binds plaques, and reduces amyloid in vivo. J. Biol. Chem. 2005, 280, 5892-5901. [CrossRef]

133. Wang, P.; Su, C.; Li, R.; Wang, H.; Ren, Y.; Sun, H.; Yang, J.; Sun, J.; Shi, J.; Tian, J.; et al. Mechanisms and effects of curcumin on spatial learning and memory improvement in APPswe/PS1dE9 mice. J. Neurosci. Res. 2014, 92, 218-231. [CrossRef]

134. Reddy, P.H.; Manczak, M.; Yin, X.; Grady, M.C.; Mitchell, A.; Kandimalla, R.; Kuruva, C.S. Protective effects of a natural product, curcumin, against amyloid beta induced mitochondrial and synaptic toxicities in Alzheimer's disease. J. Investig. Med. 2016, 64, 1220-1234. 
135. Liu, Z.-J.; Li, Z.-H.; Liu, L.; Tang, W.-X.; Wang, Y.; Dong, M.-R.; Xiao, C. Curcumin Attenuates Beta-Amyloid-Induced Neuroinflammation via Activation of Peroxisome Proliferator-Activated Receptor-Gamma Function in a Rat Model of Alzheimer's Disease. Front. Pharmacol. 2016, 7, 261. [CrossRef]

136. Lin, R.; Chen, X.; Li, W.; Han, Y.; Liu, P.; Pi, R. Exposure to metal ions regulates mRNA levels of APP and BACE1 in PC12 cells: Blockage by curcumin. Neurosci. Lett. 2008, 440, 344-347. [CrossRef]

137. Xiong, Z.; Hongmei, Z.; Lu, S.; Yu, L. Curcumin mediates presenilin-1 activity to reduce beta-amyloid production in a model of Alzheimer's Disease. Pharmacol. Rep. PR 2011, 63, 1101-1108. [CrossRef]

138. Xie, H.; Wang, J.R.; Yau, L.F.; Liu, Y.; Liu, L.; Han, Q.B.; Zhao, Z.; Jiang, Z.H. Catechins and procyanidins of Ginkgo biloba show potent activities towards the inhibition of beta-amyloid peptide aggregation and destabilization of preformed fibrils. Molecules 2014, 19, 5119-5134. [CrossRef]

139. Belviranl, M.; Okudan, N. The effects of Ginkgo biloba extract on cognitive functions in aged female rats: The role of oxidative stress and brain-derived neurotrophic factor. Behav. Brain Res. 2015, 278, 453-461. [CrossRef]

140. Zhang, L.-D.; Ma, L.; Zhang, L.; Dai, J.-G.; Chang, L.-G.; Huang, P.-L.; Tian, X.-Q. Hyperbaric Oxygen and Ginkgo Biloba Extract Ameliorate Cognitive and Memory Impairment via Nuclear Factor Kappa-B Pathway in Rat Model of Alzheimer's Disease. Chin. Med. J. 2015, 128, 3088-3093. [CrossRef]

141. Colciaghi, F.; Borroni, B.; Zimmermann, M.; Bellone, C.; Longhi, A.; Padovani, A.; Cattabeni, F.; Christen, Y.; Di Luca, M. Amyloid precursor protein metabolism is regulated toward alpha-secretase pathway by Ginkgo biloba extracts. Neurobiol. Dis. 2004, 16, 454-460. [CrossRef]

142. Yao, Z.X.; Han, Z.; Drieu, K.; Papadopoulos, V. Ginkgo biloba extract (Egb 761) inhibits $\beta$-amyloid production by lowering free cholesterol levels. J. Nutr. Biochem. 2004, 15, 749-756. [CrossRef]

143. Samarghandian, S.; Azimi-Nezhad, M.; Samini, F.; Farkhondeh, T. The Role of Saffron in Attenuating Age-related Oxidative Damage in Rat Hippocampus. Recent Pat. Food Nutr. Agric. 2016, 8, 183-189. [CrossRef]

144. Moallem, S.A.; Hariri, A.T.; Mahmoudi, M.; Hosseinzadeh, H. Effect of aqueous extract of Crocus sativus L. (saffron) stigma against subacute effect of diazinon on specific biomarkers in rats. Toxicol. Ind. Health 2012, 30, 141-146. [CrossRef] [PubMed]

145. Papandreou, M.A.; Kanakis, C.D.; Polissiou, M.G.; Efthimiopoulos, S.; Cordopatis, P.; Margarity, M.; Lamari, F.N. Inhibitory activity on amyloid-beta aggregation and antioxidant properties of Crocus sativus stigmas extract and its crocin constituents. J. Agric. Food Chem. 2006, 54, 8762-8768. [CrossRef] [PubMed]

146. Dastmalchi, K.; Damien Dorman, H.J.; Oinonen, P.P.; Darwis, Y.; Laakso, I.; Hiltunen, R. Chemical composition and in vitro antioxidative activity of a lemon balm (Melissa officinalis L.) extract. LWT Food Sci. Technol. 2008, 41, 391-400. [CrossRef]

147. Ozarowski, M.; Mikolajczak, P.L.; Piasecka, A.; Kachlicki, P.; Kujawski, R.; Bogacz, A.; Bartkowiak-Wieczorek, J.; Szulc, M.; Kaminska, E.; Kujawska, M.; et al. Influence of the Melissa officinalis Leaf Extract on Long-Term Memory in Scopolamine Animal Model with Assessment of Mechanism of Action. Evid. Based Complement. Altern. Med. 2016, 2016, 9729818. [CrossRef] [PubMed]

148. Schimidt, H.L.; Garcia, A.; Martins, A.; Mello-Carpes, P.B.; Carpes, F.P. Green tea supplementation produces better neuroprotective effects than red and black tea in Alzheimer-like rat model. Food Res. Int. 2017, 100, 442-448. [CrossRef] [PubMed]

149. Li, Q.; Zhao, H.F.; Zhang, Z.F.; Liu, Z.G.; Pei, X.R.; Wang, J.B.; Li, Y. Long-term green tea catechin administration prevents spatial learning and memory impairment in senescence-accelerated mouse prone- 8 mice by decreasing Abeta1-42 oligomers and upregulating synaptic plasticity-related proteins in the hippocampus. Neuroscience 2009, 163, 741-749. [CrossRef] [PubMed]

150. Li, H.; Wu, X.; Wu, Q.; Gong, D.; Shi, M.; Guan, L.; Zhang, J.; Liu, J.; Yuan, B.; Han, G.; et al. Green tea polyphenols protect against okadaic acid-induced acute learning and memory impairments in rats. Nutrition 2014, 30, 337-342. [CrossRef] [PubMed]

151. Kerem, K.U.; Cengiz, U.M.; Neslihan, T.; Derya, U.; Emine, C.; Emre, E. The Anti-Inflammatory and Antioxidant Effects of Salvia officinalis on Lipopolysaccharide-Induced Inflammation in Rats. J. Med. Food 2017, 20, 1193-1200.

152. Manalo, R.V.; Silvestre, M.A.; Barbosa, A.L.A.; Medina, P.M. Coconut (Cocos nucifera) Ethanolic Leaf Extract Reduces Amyloid- $\beta$ (1-42) Aggregation and Paralysis Prevalence in Transgenic Caenorhabditis elegans Independently of Free Radical Scavenging and Acetylcholinesterase Inhibition. Biomedicines 2017, 5, 17. [CrossRef] 
153. Rahim, N.S.; Lim, S.M.; Mani, V.; Abdul Majeed, A.B.; Ramasamy, K. Enhanced memory in Wistar rats by virgin coconut oil is associated with increased antioxidative, cholinergic activities and reduced oxidative stress. Pharm. Biol. 2017, 55, 825-832. [CrossRef]

154. Bansal, A.; Kirschner, M.; Zu, L.; Cai, D.; Zhang, L. Coconut Oil Decreases Expression of Amyloid Precursor Protein (APP) and Secretion of Amyloid Peptides throughInhibitionof ADP-ribosylation factor 1 (ARF1). Brain Res. 2018. [CrossRef]

155. Cheng, D.; Xi, Y.; Cao, J.; Cao, D.; Ma, Y.; Jiang, W. Protective effect of apple (Ralls) polyphenol extract against aluminum-induced cognitive impairment and oxidative damage in rat. NeuroToxicology 2014, 45, 111-120. [CrossRef]

156. Chan, A.; Shea, T.B. Dietary Supplementation with Apple Juice Decreases Endogenous Amyloid-beta Levels in Murine Brain. J. Alzheimers Dis. 2009, 16, 167-171. [CrossRef]

157. Fuentealba, J.; Dibarrart, A.J.; Fuentes-Fuentes, M.C.; Saez-Orellana, F.; Quiñones, K.; Guzmán, L.; Perez, C.; Becerra, J.; Aguayo, L.G. Synaptic failure and adenosine triphosphate imbalance induced by amyloid- $\beta$ aggregates are prevented by blueberry-enriched polyphenols extract. J. Neurosci. Res. 2011, 89, 1499-1508. [CrossRef]

158. Shukitt-Hale, B.; Lau, F.C.; Carey, A.N.; Galli, R.L.; Spangler, E.L.; Ingram, D.K.; Joseph, J.A. Blueberry polyphenols attenuate kainic acid-induced decrements in cognition and alter inflammatory gene expression in rat hippocampus. Nutr. Neurosci. 2008, 11, 172-182. [CrossRef]

159. Zhu, Y.; Bickford, P.C.; Sanberg, P.; Giunta, B.; Tan, J. Blueberry opposes $\beta$-amyloid peptide-induced microglial activation via inhibition of p44/42 mitogen-activation protein kinase. Rejuvenation Res. 2008, 11, 891-901. [CrossRef]

160. Tan, L.; Yang, H.; Pang, W.; Li, H.; Liu, W.; Sun, S.; Song, N.; Zhang, W.; Jiang, Y. Investigation on the Role of BDNF in the Benefits of Blueberry Extracts for the Improvement of Learning and Memory in Alzheimer's Disease Mouse Model. J. Alzheimers Dis. 2017, 56, 629-640. [CrossRef]

161. Kadakkuzha, B.M.; Liu, X.-A.; Swarnkar, S.; Chen, Y. Chapter 18-Genomic and Proteomic Mechanisms and Models in Toxicity and Safety Evaluation of Nutraceuticals. In Nutraceuticals; Gupta, R.C., Ed.; Academic Press: Boston, MA, USA, 2016; pp. 227-237.

162. Schuster, D.; Rajendran, A.; Hui, S.W.; Nicotera, T.; Srikrishnan, T.; Kruzel, M.L. Protective effect of colostrinin on neuroblastoma cell survival is due to reduced aggregation of $\beta$-amyloid. Neuropeptides 2005, 39, 419-426. [CrossRef]

163. Stewart, M.G. Colostrinin ${ }^{\mathrm{TM}}$ : A naturally occurring compound derived from mammalian colostrum with efficacy in treatment of neurodegenerative diseases, including Alzheimer's. Expert Opin. Pharmacother. 2008, 9, 2553-2559. [CrossRef]

164. Walker, J.M.; Klakotskaia, D.; Ajit, D.; Weisman, G.A.; Wood, W.G.; Sun, G.Y.; Serfozo, P.; Simonyi, A.; Schachtman, T.R. Beneficial effects of dietary EGCG and voluntary exercise on behavior in an Alzheimer's disease mouse model. J. Alzheimers Dis. 2015, 44, 561-572. [CrossRef]

165. Harvey, B.S.; Musgrave, I.F.; Ohlsson, K.S.; Fransson, A.; Smid, S.D. The green tea polyphenol (-)-epigallocatechin-3-gallate inhibits amyloid- $\beta$ evoked fibril formation and neuronal cell death in vitro. Food Chem. 2011, 129, 1729-1736. [CrossRef]

166. Abbas, S.; Wink, M. Epigallocatechin gallate inhibits beta amyloid oligomerization in Caenorhabditis elegans and affects the daf-2/insulin-like signaling pathway. Phytomedicine Int. J. Phytother. Phytopharm. 2010, 17, 902-909. [CrossRef]

167. Wobst, H.J.; Sharma, A.; Diamond, M.I.; Wanker, E.E.; Bieschke, J. The green tea polyphenol (-)-epigallocatechin gallate prevents the aggregation of tau protein into toxic oligomers at substoichiometric ratios. FEBS Lett. 2015, 589, 77-83. [CrossRef]

168. Chesser, A.S.; Ganeshan, V.; Yang, J.; Johnson, G.V.W. Epigallocatechin-3-gallate enhances clearance of phosphorylated tau in primary neurons. Nutr. Neurosci. 2016, 19, 21-31. [CrossRef]

169. Biasibetti, R.; Tramontina, A.C.; Costa, A.P.; Dutra, M.F.; Quincozes-Santos, A.; Nardin, P.; Bernardi, C.L.; Wartchow, K.M.; Lunardi, P.S.; Gonçalves, C.A. Green tea (-)epigallocatechin-3-gallate reverses oxidative stress and reduces acetylcholinesterase activity in a streptozotocin-induced model of dementia. Behav. Brain Res. 2013, 236, 186-193. [CrossRef] 
170. Lee, Y.J.; Choi, D.Y.; Yun, Y.P.; Han, S.B.; Oh, K.W.; Hong, J.T. Epigallocatechin-3-gallate prevents systemic inflammation-induced memory deficiency and amyloidogenesis via its anti-neuroinflammatory properties. J. Nutr. Biochem. 2013, 24, 298-310. [CrossRef]

171. Ono, K.; Yoshiike, Y.; Takashima, A.; Hasegawa, K.; Naiki, H.; Yamada, M. Vitamin A exhibits potent antiamyloidogenic and fibril-destabilizing effects in vitro. Exp. Neurol. 2004, 189, 380-392. [CrossRef]

172. Koryakina, A.; Aeberhard, J.; Kiefer, S.; Hamburger, M.; Kuenzi, P. Regulation of secretases by all-trans-retinoic acid. FEBS J. 2009, 276, 2645-2655. [CrossRef]

173. Kapoor, A.; Wang, B.J.; Hsu, W.M.; Chang, M.Y.; Liang, S.M.; Liao, Y.F. Retinoic acid-elicited RARalpha/RXRalpha signaling attenuates Abeta production by directly inhibiting gamma-secretase-mediated cleavage of amyloid precursor protein. ACS Chem. Neurosci. 2013, 4, 1093-1100. [CrossRef]

174. Ding, Y.; Qiao, A.; Wang, Z.; Goodwin, J.S.; Lee, E.-S.; Block, M.L.; Allsbrook, M.; McDonald, M.P.; Fan, G.-H. Retinoic Acid Attenuates $\beta$-Amyloid Deposition and Rescues Memory Deficits in an Alzheimer's Disease Transgenic Mouse Model. J. Neurosci. 2008, 28, 11622-11634. [CrossRef]

175. Arendash, G.W.; Mori, T.; Cao, C.; Mamcarz, M.; Runfeldt, M.; Dickson, A.; Rezai-Zadeh, K.; Tane, J.; Citron, B.A.; Lin, X.; et al. Caffeine reverses cognitive impairment and decreases brain amyloid-beta levels in aged Alzheimer's disease mice. J. Alzheimers Dis. 2009, 17, 661-680. [CrossRef]

176. Sharma, B.; Kalita, S.; Paul, A.; Mandal, B.; Paul, S. The role of caffeine as an inhibitor in the aggregation of amyloid forming peptides: A unified molecular dynamics simulation and experimental study. RSC Adv. 2016, 6, 78548-78558. [CrossRef]

177. Qosa, H.; Abuznait, A.H.; Hill, R.A.; Kaddoumi, A. Enhanced brain amyloid-beta clearance by rifampicin and caffeine as a possible protective mechanism against Alzheimer's disease. J. Alzheimers Dis. 2012, 31, 151-165. [CrossRef]

178. Ullah, F.; Ali, T.; Ullah, N.; Kim, M.O. Caffeine prevents d-galactose-induced cognitive deficits, oxidative stress, neuroinflammation and neurodegeneration in the adult rat brain. Neurochem. Int. 2015, 90, 114-124. [CrossRef]

179. Laurent, C.; Eddarkaoui, S.; Derisbourg, M.; Leboucher, A.; Demeyer, D.; Carrier, S.; Schneider, M.; Hamdane, M.; Muller, C.E.; Buee, L.; et al. Beneficial effects of caffeine in a transgenic model of Alzheimer's disease-like tau pathology. Neurobiol. Aging 2014, 35, 2079-2090. [CrossRef]

180. Bend, J.R.; Xia, X.Y.; Chen, D.; Awaysheh, A.; Lo, A.; Rieder, M.J.; Jane Rylett, R. Attenuation of oxidative stress in HEK 293 cells by the TCM constituents schisanhenol, baicalein, resveratrol or crocetin and two defined mixtures. J. Pharm. Pharm. Sci. 2015, 18, 661-682. [CrossRef]

181. Lu, J.H.; Ardah, M.T.; Durairajan, S.S.; Liu, L.F.; Xie, L.X.; Fong, W.F.; Hasan, M.Y.; Huang, J.D.; El-Agnaf, O.M.; Li, M. Baicalein inhibits formation of alpha-synuclein oligomers within living cells and prevents Abeta peptide fibrillation and oligomerisation. Chembiochem. A Eur. J. Chem. Biol. 2011, 12, 615-624. [CrossRef]

182. Zhang, S.Q.; Obregon, D.; Ehrhart, J.; Deng, J.; Tian, J.; Hou, H.; Giunta, B.; Sawmiller, D.; Tan, J. Baicalein reduces beta-amyloid and promotes nonamyloidogenic amyloid precursor protein processing in an Alzheimer's disease transgenic mouse model. J. Neurosci. Res. 2013, 91, 1239-1246. [CrossRef]

183. Manca, M.L.; Marongiu, F.; Castangia, I.; Catalán-Latorre, A.; Caddeo, C.; Bacchetta, G.; Ennas, G.; Zaru, M.; Fadda, A.M.; Manconi, M. Protective effect of grape extract phospholipid vesicles against oxidative stress skin damages. Ind. Crop. Prod. 2016, 83, 561-567. [CrossRef]

184. Huang, M.; Jiang, X.; Liang, Y.; Liu, Q.; Chen, S.; Guo, Y. Berberine improves cognitive impairment by promoting autophagic clearance and inhibiting production of $\beta$-amyloid in APP/tau/PS1 mouse model of Alzheimer's disease. Exp. Gerontol. 2017, 91, 25-33. [CrossRef]

185. He, W.; Wang, C.; Chen, Y.; He, Y.; Cai, Z. Berberine attenuates cognitive impairment and ameliorates tau hyperphosphorylation by limiting the self-perpetuating pathogenic cycle between NF- $\mathrm{BB}$ signaling, oxidative stress and neuroinflammation. Pharmacol. Rep. 2017, 69, 1341-1348. [CrossRef] [PubMed]

186. Beg, T.; Jyoti, S.; Naz, F.; Ali, F.; Ali, S.K.; Reyad, A.M.; Siddique, Y.H. Protective Effect of Kaempferol on the Transgenic Drosophila Model of Alzheimer's Disease. CNS Neurol. Disord. Drug Targets 2018, 17, 421-429. [CrossRef] [PubMed]

187. Garcia-Mediavilla, V.; Crespo, I.; Collado, P.S.; Esteller, A.; Sanchez-Campos, S.; Tunon, M.J.; Gonzalez-Gallego, J. The anti-inflammatory flavones quercetin and kaempferol cause inhibition of inducible nitric oxide synthase, cyclooxygenase- 2 and reactive C-protein, and down-regulation of the nuclear factor kappaB pathway in Chang Liver cells. Eur. J. Pharmacol. 2007, 557, 221-229. [CrossRef] 
188. Akaishi, T.; Morimoto, T.; Shibao, M.; Watanabe, S.; Sakai-Kato, K.; Utsunomiya-Tate, N.; Abe, K. Structural requirements for the flavonoid fisetin in inhibiting fibril formation of amyloid beta protein. Neurosci. Lett. 2008, 444, 280-285. [CrossRef] [PubMed]

189. Ono, K.; Yoshiike, Y.; Takashima, A.; Hasegawa, K.; Naiki, H.; Yamada, M. Potent anti-amyloidogenic and fibril-destabilizing effects of polyphenols in vitro: Implications for the prevention and therapeutics of Alzheimer's disease. J. Neurochem. 2003, 87, 172-181. [CrossRef] [PubMed]

190. Shimmyo, Y.; Kihara, T.; Akaike, A.; Niidome, T.; Sugimoto, H. Flavonols and flavones as BACE-1 inhibitors: Structure-activity relationship in cell-free, cell-based and in silico studies reveal novel pharmacophore features. Biochim. Biophys. Acta 2008, 1780, 819-825. [CrossRef] [PubMed]

191. Kim, J.H.; Lee, J.; Lee, S.; Cho, E.J. Quercetin and quercetin-3- $\beta$-d-glucoside improve cognitive and memory function in Alzheimer's disease mouse. Appl. Biol. Chem. 2016, 59, 721-728. [CrossRef]

192. Regitz, C.; Dussling, L.M.; Wenzel, U. Amyloid-beta (Abeta(1)(-)(4)(2))-induced paralysis in Caenorhabditis elegans is inhibited by the polyphenol quercetin through activation of protein degradation pathways. Mol. Nutr. Food Res. 2014, 58, 1931-1940. [CrossRef]

193. Jimenez-Aliaga, K.; Bermejo-Bescos, P.; Benedi, J.; Martin-Aragon, S. Quercetin and rutin exhibit antiamyloidogenic and fibril-disaggregating effects in vitro and potent antioxidant activity in APPswe cells. Life Sci. 2011, 89, 939-945. [CrossRef]

194. Zhang, X.; Hu, J.; Zhong, L.; Wang, N.; Yang, L.; Liu, C.C.; Li, H.; Wang, X.; Zhou, Y.; Zhang, Y.; et al. Quercetin stabilizes apolipoprotein e and reduces brain A $\beta$ levels in amyloid model mice. Neuropharmacology 2016, 108, 179-192. [CrossRef]

195. Sabogal-Guáqueta, A.M.; Muñoz-Manco, J.I.; Ramírez-Pineda, J.R.; Lamprea-Rodriguez, M.; Osorio, E.; Cardona-Gómez, G.P. The flavonoid quercetin ameliorates Alzheimer's disease pathology and protects cognitive and emotional function in aged triple transgenic Alzheimer's disease model mice. Neuropharmacology 2015, 93, 134-145. [CrossRef] [PubMed]

196. Prakash, D.; Sudhandiran, G. Dietary flavonoid fisetin regulates aluminium chloride-induced neuronal apoptosis in cortex and hippocampus of mice brain. J. Nutr. Biochem. 2015, 26, 1527-1539. [CrossRef] [PubMed]

197. Ahmad, A.; Ali, T.; Park, H.Y.; Badshah, H.; Rehman, S.U.; Kim, M.O. Neuroprotective Effect of Fisetin Against Amyloid-Beta-Induced Cognitive/Synaptic Dysfunction, Neuroinflammation, and Neurodegeneration in Adult Mice. Mol. Neurobiol. 2017, 54, 2269-2285. [CrossRef] [PubMed]

198. Kim, S.; Choi, K.J.; Cho, S.J.; Yun, S.M.; Jeon, J.P.; Koh, Y.H.; Song, J.; Johnson, G.V.W.; Jo, C. Fisetin stimulates autophagic degradation of phosphorylated tau via the activation of TFEB and Nrf2 transcription factors. Sci. Rep. 2016, 6, 24933. [CrossRef] [PubMed]

199. Pourkhodadad, S.; Alirezaei, M.; Moghaddasi, M.; Ahmadvand, H.; Karami, M.; Delfan, B.; Khanipour, Z. Neuroprotective effects of oleuropein against cognitive dysfunction induced by colchicine in hippocampal CA1 area in rats. J. Physiol. Sci. 2016, 66, 397-405. [CrossRef] [PubMed]

200. Luccarini, I.; Ed Dami, T.; Grossi, C.; Rigacci, S.; Stefani, M.; Casamenti, F. Oleuropein aglycone counteracts A 342 toxicity in the rat brain. Neurosci. Lett. 2014, 558, 67-72. [CrossRef]

201. Pantano, D.; Luccarini, I.; Nardiello, P.; Servili, M.; Stefani, M.; Casamenti, F. Oleuropein aglycone and polyphenols from olive mill waste water ameliorate cognitive deficits and neuropathology. Br. J. Clin. Pharmacol. 2017, 83, 54-62. [CrossRef]

202. Stefania, R.; Valentina, G.; Monica, B.; Daniela, N.; Annalisa, R.; Andrea, B.; Massimo, S. A $\beta(1-42)$ Aggregates into Non-Toxic Amyloid Assemblies in the Presence of the Natural Polyphenol Oleuropein Aglycon. Curr. Alzheimer Res. 2011, 8, 841-852.

203. Kostomoiri, M.; Fragkouli, A.; Sagnou, M.; Skaltsounis, L.A.; Pelecanou, M.; Tsilibary, E.C.; Tzinia, A.K. Oleuropein, an Anti-oxidant Polyphenol Constituent of Olive Promotes $\alpha$-Secretase Cleavage of the Amyloid Precursor Protein (AßPP). Cell. Mol. Neurobiol. 2013, 33, 147-154. [CrossRef]

204. Daccache, A.; Lion, C.; Sibille, N.; Gerard, M.; Slomianny, C.; Lippens, G.; Cotelle, P. Oleuropein and derivatives from olives as Tau aggregation inhibitors. Neurochem. Int. 2011, 58, 700-707. [CrossRef]

205. Mori, T.; Rezai-Zadeh, K.; Koyama, N.; Arendash, G.W.; Yamaguchi, H.; Kakuda, N.; Horikoshi-Sakuraba, Y.; Tan, J.; Town, T. Tannic acid is a natural beta-secretase inhibitor that prevents cognitive impairment and mitigates Alzheimer-like pathology in transgenic mice. J. Biol. Chem. 2012, 287, 6912-6927. [CrossRef] 
206. Ono, K.; Hasegawa, K.; Naiki, H.; Yamada, M. Anti-amyloidogenic activity of tannic acid and its activity to destabilize Alzheimer's $\beta$-amyloid fibrils in vitro. Biochim. Biophys. Acta (BBA) Mol. Basis Dis. 2004, 1690, 193-202. [CrossRef]

207. Yao, J.; Gao, X.; Sun, W.; Yao, T.; Shi, S.; Ji, L. Molecular hairpin: A possible model for inhibition of tau aggregation by tannic acid. Biochemistry 2013, 52, 1893-1902. [CrossRef]

208. Ghahghaei, A.; Bathaie, S.Z.; Bahraminejad, E. Mechanisms of the Effects of Crocin on Aggregation and Deposition of A $\beta 1-40$ Fibrils in Alzheimer's Disease. Int. J. Pept. Res. 2012, 18, 347-351. [CrossRef]

209. Ghahghaei, A.; Bathaie, S.Z.; Kheirkhah, H.; Bahraminejad, E. The protective effect of crocin on the amyloid fibril formation of Abeta42 peptide in vitro. Cell. Mol. Biol. Lett. 2013, 18, 328-339. [CrossRef]

210. Naghizadeh, B.; Mansouri, M.T.; Ghorbanzadeh, B. Protective effects of crocin against streptozotocin-induced oxidative damage in rat striatum. Acta Med. Iran 2014, 52, 101-105.

211. Heidari, S.; Mehri, S.; Hosseinzadeh, H. Memory enhancement and protective effects of crocin against D-galactose aging model in the hippocampus of Wistar rats. Iran. J. Basic Med. Sci. 2017, 20, 1250-1259.

212. Zhang, Z.; Wu, H.; Huang, H. Epicatechin Plus Treadmill Exercise are Neuroprotective Against Moderate-stage Amyloid Precursor Protein/Presenilin 1 Mice. Pharmacogn. Mag. 2016, 12, S139-S146.

213. Zeng, Y.Q.; Wang, Y.J.; Zhou, X.F. Effects of (-)epicatechin on the pathology of APP/PS1 transgenic mice. Front. Neurol. 2014, 5, 69. [CrossRef]

214. Cox, C.J.; Choudhry, F.; Peacey, E.; Perkinton, M.S.; Richardson, J.C.; Howlett, D.R.; Lichtenthaler, S.F.; Francis, P.T.; Williams, R.J. Dietary (-)-epicatechin as a potent inhibitor of betagamma-secretase amyloid precursor protein processing. Neurobiol. Aging 2015, 36, 178-187. [CrossRef]

215. George, R.C.; Lew, J.; Graves, D.J. Interaction of cinnamaldehyde and epicatechin with tau: Implications of beneficial effects in modulating alzheimer's disease pathogenesis. J. Alzheimer's Dis. 2013, 36, 21-40. [CrossRef]

216. Carbonaro, M.; Di Venere, A.; Filabozzi, A.; Maselli, P.; Minicozzi, V.; Morante, S.; Nicolai, E.; Nucara, A.; Placidi, E.; Stellato, F. Role of dietary antioxidant (-)-epicatechin in the development of $\beta$-lactoglobulin fibrils. Biochim. Biophys. Acta (BBA) Proteins Proteom. 2016, 1864, 766-772. [CrossRef] [PubMed]

217. Hajipour, S.; Sarkaki, A.; Farbood, Y.; Eidi, A.; Mortazavi, P.; Valizadeh, Z. Effect of gallic acid on dementia type of Alzheimer disease in rats: Electrophysiological and histological studies. Basic Clin. Neurosci. 2016, 7, 97-106. [CrossRef]

218. Kim, M.J.; Seong, A.R.; Yoo, J.Y.; Jin, C.H.; Lee, Y.H.; Kim, Y.J.; Lee, J.; Jun, W.J.; Yoon, H.G. Gallic acid, a histone acetyltransferase inhibitor, suppresses beta-amyloid neurotoxicity by inhibiting microglial-mediated neuroinflammation. Mol. Nutr. Food Res. 2011, 55, 1798-1808. [CrossRef]

219. Jayamani, J.; Shanmugam, G. Gallic acid, one of the components in many plant tissues, is a potential inhibitor for insulin amyloid fibril formation. Eur. J. Med. Chem. 2014, 85, 352-358. [CrossRef]

220. Valizadeh, Z.; Eidi, A.; Sarkaki, A.; Farbood, Y.; Mortazavi, P. Dementia type of Alzheimer's disease due to beta-amyloid was improved by Gallic acid in rats. HealthMED 2012, 6, 3648-3656.

221. Tsai, F.-S.; Wu, L.-Y.; Yang, S.-E.; Cheng, H.-Y.; Tsai, C.-C.; Wu, C.-R.; Lin, L.-W. Ferulic Acid Reverses the Cognitive Dysfunction Caused by Amyloid $\beta$ Peptide 1-40 Through Anti-Oxidant Activity and Cholinergic Activation in Rats. Am. J. Chin. Med. 2015, 43, 319-335. [CrossRef] [PubMed]

222. Mori, T.; Koyama, N.; Guillot-Sestier, M.V.; Tan, J.; Town, T. Ferulic acid is a nutraceutical beta-secretase modulator that improves behavioral impairment and alzheimer-like pathology in transgenic mice. PLoS ONE 2013, 8, e55774. [CrossRef] [PubMed]

223. Zhang, Y.; Cui, L.; Zhang, Y.; Cao, H.; Wang, Y.; Teng, T.; Ma, G.; Li, Y.; Li, K. Ferulic acid inhibits the transition of amyloid- $\beta 42$ monomers to oligomers but accelerates the transition from oligomers to fibrils. J. Alzheimer's Dis. 2013, 37, 19-28.

224. Yan, J.J.; Jung, J.S.; Kim, T.K.; Hasan, M.A.; Hong, C.W.; Nam, J.S.; Song, D.K. Protective effects of ferulic acid in amyloid precursor protein plus presenilin-1 transgenic mouse model of Alzheimer disease. Biol. Pharm. Bull. 2013, 36, 140-143. [CrossRef]

225. Ono, K.; Hirohata, M.; Yamada, M. Ferulic acid destabilizes preformed beta-amyloid fibrils in vitro. Biochem. Biophys. Res. Commun. 2005, 336, 444-449. [CrossRef] [PubMed]

226. Xu, P.-X.; Wang, S.-W.; Yu, X.-L.; Su, Y.-J.; Wang, T.; Zhou, W.-W.; Zhang, H.; Wang, Y.-J.; Liu, R.-T. Rutin improves spatial memory in Alzheimer's disease transgenic mice by reducing $A \beta$ oligomer level and attenuating oxidative stress and neuroinflammation. Behav. Brain Res. 2014, 264, 173-180. [CrossRef] 
227. Lee, Y.W.; Kim, D.H.; Jeon, S.J.; Park, S.J.; Kim, J.M.; Jung, J.M.; Lee, H.E.; Bae, S.G.; Oh, H.K.; Ho Son, K.H.; et al. Neuroprotective effects of salvianolic acid B on an A $325-35$ peptide-induced mouse model of Alzheimer's disease. Eur. J. Pharmacol. 2013, 704, 70-77. [CrossRef] [PubMed]

228. Durairajan, S.S.; Yuan, Q.; Xie, L.; Chan, W.S.; Kum, W.F.; Koo, I.; Liu, C.; Song, Y.; Huang, J.D.; Klein, W.L.; et al. Salvianolic acid B inhibits Abeta fibril formation and disaggregates preformed fibrils and protects against Abeta-induced cytotoxicty. Neurochem. Int. 2008, 52, 741-750. [CrossRef] [PubMed]

229. Tang, Y.; Huang, D.; Zhang, M.H.; Zhang, W.S.; Tang, Y.X.; Shi, Z.X.; Deng, L.; Zhou, D.H.; Lu, X.Y. Salvianolic acid B inhibits A $\beta$ generation by modulating BACE1 activity in SH-SY5Y-APPsw cells. Nutrients 2016, 8, 333. [CrossRef] [PubMed]

230. Fiori, J.; Naldi, M.; Bartolini, M.; Andrisano, V. Disclosure of a fundamental clue for the elucidation of the myricetin mechanism of action as amyloid aggregation inhibitor by mass spectrometry. Electrophoresis 2012, 33, 3380-3386. [CrossRef] [PubMed]

231. Shimmyo, Y.; Kihara, T.; Akaike, A.; Niidome, T.; Sugimoto, H. Multifunction of myricetin on A beta: Neuroprotection via a conformational change of A beta and reduction of A beta via the interference of secretases. J. Neurosci. Res. 2008, 86, 368-377. [CrossRef] [PubMed]

232. Ramezani, M.; Darbandi, N.; Khodagholi, F.; Hashemi, A. Myricetin protects hippocampal CA3 pyramidal neurons and improves learning and memory impairments in rats with Alzheimer's disease. Neural Regen Res. 2016, 11, 1976-1980. [CrossRef] [PubMed]

233. Md, S.; Gan, S.Y.; Haw, Y.H.; Ho, C.L.; Wong, S.; Choudhury, H. In vitro neuroprotective effects of naringenin nanoemulsion against $\beta$-amyloid toxicity through the regulation of amyloidogenesis and tau phosphorylation. Int. J. Biol. Macromol. 2018, 118, 1211-1219. [CrossRef] [PubMed]

234. Yang, W.; Ma, J.; Liu, Z.; Lu, Y.; Hu, B.; Yu, H. Effect of naringenin on brain insulin signaling and cognitive functions in ICV-STZ induced dementia model of rats. Neurol. Sci. 2014, 35, 741-751. [CrossRef]

235. Ghofrani, S.; Joghataei, M.-T.; Mohseni, S.; Baluchnejadmojarad, T.; Bagheri, M.; Khamse, S.; Roghani, M. Naringenin improves learning and memory in an Alzheimer's disease rat model: Insights into the underlying mechanisms. Eur. J. Pharmacol. 2015, 764, 195-201. [CrossRef]

236. Wu, L.-H.; Lin, C.; Lin, H.-Y.; Liu, Y.-S.; Wu, C.Y.-J.; Tsai, C.-F.; Chang, P.-C.; Yeh, W.-L.; Lu, D.-Y. Naringenin Suppresses Neuroinflammatory Responses Through Inducing Suppressor of Cytokine Signaling 3 Expression. Mol. Neurobiol. 2016, 53, 1080-1091. [CrossRef]

237. Zhang, J.X.; Xing, J.G.; Wang, L.L.; Jiang, H.L.; Guo, S.L.; Liu, R. Luteolin inhibits fibrillary $\beta$-amyloid1-40 -induced inflammation in a human blood-brain barrier mode by suppressing the p38 MAPK-mediated NF-екB signaling pathways. Molecules 2017, 22. [CrossRef]

238. Liu, R.; Gao, M.; Qiang, G.F.; Zhang, T.T.; Lan, X.; Ying, J.; Du, G.H. The anti-amnesic effects of luteolin against amyloid $\beta 25-35$ peptide-induced toxicity in mice involve the protection of neurovascular unit. Neuroscience 2009, 162, 1232-1243. [CrossRef]

239. Wang, H.; Wang, H.; Cheng, H.; Che, Z. Ameliorating effect of luteolin on memory impairment in an Alzheimer's disease model. Mol. Med. Rep. 2016, 13, 4215-4220. [CrossRef]

240. Zheng, N.; Yuan, P.; Li, C.; Wu, J.; Huang, J. Luteolin Reduces BACE1 Expression through NF-kB and Estrogen Receptor Mediated Pathways in HEK293 and SH-SY5Y Cells. J. Alzheimer's Dis. 2015, 45, 659-671. [CrossRef]

241. Sawmiller, D.; Li, S.; Shahaduzzaman, M.; Smith, A.J.; Obregon, D.; Giunta, B.; Borlongan, C.V.; Sanberg, P.R.; Tan, J. Luteolin Reduces Alzheimer's Disease Pathologies Induced by Traumatic Brain Injury. Int. J. Mol. Sci. 2014, 15, 895-904. [CrossRef]

242. Patil, S.P.; Maki, S.; Khedkar, S.A.; Rigby, A.C.; Chan, C. Withanolide A and Asiatic Acid Modulate Multiple Targets Associated with Amyloid-beta Precursor Protein Processing and Amyloid-beta Protein Clearance. J. Nat. Prod. 2010, 73, 1196-1202. [CrossRef]

243. Dhanasekaran, M.; Holcomb, L.A.; Hitt, A.R.; Tharakan, B.; Porter, J.W.; Young, K.A.; Manyam, B.V. Centella asiatica extract selectively decreases amyloid $\beta$ levels in hippocampus of Alzheimer's disease animal model. Phytother. Res. 2009, 23, 14-19. [CrossRef]

244. Veerendra Kumar, M.H.; Gupta, Y.K. Effect of Centella asiatica on cognition and oxidative stress in an intracerebroventricular streptozotocin model of Alzheimer's disease in rats. Clin. Exp. Pharmacol. Physiol. 2003, 30, 336-342. [CrossRef] 
245. Mei, Z.R.; Tan, X.P.; Liu, S.Z.; Huang, H.H. Puerarin alleviates cognitive impairment and tau hyperphosphorylation in APP/PS1 transgenic mice. Zhongguo Zhongyao Zazhi 2016, 41, 3285-3289.

246. Zhao, S.S.; Yang, W.N.; Jin, H.; Ma, K.G.; Feng, G.F. Puerarin attenuates learning and memory impairments and inhibits oxidative stress in STZ-induced SAD mice. NeuroToxicol 2015, 51, 166-171. [CrossRef]

247. Mahdy, H.M.; Mohamed, M.R.; Emam, M.A.; Karim, A.M.; Abdel-Naim, A.B.; Khalifa, A.E. The anti-apoptotic and anti-inflammatory properties of puerarin attenuate 3-nitropropionic-acid induced neurotoxicity in rats. Can. J. Physiol. Pharmacol. 2014, 92, 252-258. [CrossRef]

248. Monti, M.C.; Margarucci, L.; Riccio, R.; Casapullo, A. Modulation of Tau Protein Fibrillization by Oleocanthal. J. Nat. Prod. 2012, 75, 1584-1588. [CrossRef]

249. Li, W.; Sperry, J.B.; Crowe, A.; Trojanowski, J.Q.; Smith, A.B., III; Lee, V.M.-Y. Inhibition of tau fibrillization by oleocanthal via reaction with the amino groups of tau. J. Neurochem. 2009, 110, 1339-1351. [CrossRef]

250. Qosa, H.; Batarseh, Y.S.; Mohyeldin, M.M.; El Sayed, K.A.; Keller, J.N.; Kaddoumi, A. Oleocanthal enhances amyloid- $\beta$ clearance from the brains of TgSwDI mice and in vitro across a human blood-brain barrier model. ACS Chem. Neurosci. 2015, 6, 1849-1859. [CrossRef]

251. Vion, E.; Page, G.; Bourdeaud, E.; Paccalin, M.; Guillard, J.; Rioux Bilan, A. Trans $\varepsilon$-viniferin is an amyloid- $\beta$ disaggregating and anti-inflammatory drug in a mouse primary cellular model of Alzheimer's disease. Mol. Cell. Neurosci. 2018, 88, 1-6. [CrossRef]

252. Jeong, H.Y.; Kim, J.Y.; Lee, H.K.; Ha, D.T.; Song, K.-S.; Bae, K.; Seong, Y.H. Leaf and stem of Vitis amurensis and its active components protect against amyloid $\beta$ protein (25-35)-induced neurotoxicity. Arch. Pharmacal Res. 2010, 33, 1655-1664. [CrossRef]

253. Rivière, C.; Papastamoulis, Y.; Fortin, P.-Y.; Delchier, N.; Andriamanarivo, S.; Waffo-Teguo, P.; Kapche, G.D.W.F.; Amira-Guebalia, H.; Delaunay, J.-C.; Mérillon, J.-M.; et al. New stilbene dimers against amyloid fibril formation. Bioorg. Med. Chem. Lett. 2010, 20, 3441-3443. [CrossRef]

254. McLaurin, J.; Kierstead, M.E.; Brown, M.E.; Hawkes, C.A.; Lambermon, M.H.; Phinney, A.L.; Darabie, A.A.; Cousins, J.E.; French, J.E.; Lan, M.F.; et al. Cyclohexanehexol inhibitors of Abeta aggregation prevent and reverse Alzheimer phenotype in a mouse model. Nat. Med. 2006, 12, 801-808. [CrossRef]

255. McLaurin, J.; Golomb, R.; Jurewicz, A.; Antel, J.P.; Fraser, P.E. Inositol stereoisomers stabilize an oligomeric aggregate of Alzheimer amyloid beta peptide and inhibit abeta -induced toxicity. J. Biol. Chem. 2000, 275, 18495-18502. [CrossRef]

256. Wang, M.; Li, Y.; Ni, C.; Song, G. Honokiol Attenuates Oligomeric Amyloid $\beta_{1-42}$-Induced Alzheimer's Disease in Mice Through Attenuating Mitochondrial Apoptosis and Inhibiting the Nuclear Factor Kappa-B Signaling Pathway. Cell. Physiol. Biochem. 2017, 43, 69-81. [CrossRef]

257. Wang, D.; Dong, X.; Wang, C. Honokiol Ameliorates Amyloidosis and Neuroinflammation and Improves Cognitive Impairment in Alzheimer's Disease Transgenic Mice. J. Pharmacol. Exp. Ther. 2018, 366, 470-478. [CrossRef]

258. Balez, R.; Steiner, N.; Engel, M.; Munoz, S.S.; Lum, J.S.; Wu, Y.; Wang, D.; Vallotton, P.; Sachdev, P.; O'Connor, M.; et al. Neuroprotective effects of apigenin against inflammation, neuronal excitability and apoptosis in an induced pluripotent stem cell model of Alzheimer's disease. Sci. Rep. 2016, 6, 31450. [CrossRef]

259. Zhao, L.; Wang, J.-L.; Liu, R.; Li, X.-X.; Li, J.-F.; Zhang, L. Neuroprotective, Anti-Amyloidogenic and Neurotrophic Effects of Apigenin in an Alzheimer's Disease Mouse Model. Molecules 2013, 18, 9949. [CrossRef]

260. Wang, Y.; Wang, Y.; Li, J.; Hua, L.; Han, B.; Zhang, Y.; Yang, X.; Zeng, Z.; Bai, H.; Yin, H.; et al. Effects of caffeic acid on learning deficits in a model of Alzheimer's disease. Int. J. Mol. Med. 2016, 38, 869-875. [CrossRef]

261. Sul, D.; Kim, H.-S.; Lee, D.; Joo, S.S.; Hwang, K.W.; Park, S.-Y. Protective effect of caffeic acid against beta-amyloid-induced neurotoxicity by the inhibition of calcium influx and tau phosphorylation. Life Sci. 2009, 84, 257-262. [CrossRef]

262. Burton, G.; Ingold, K. beta-Carotene: An unusual type of lipid antioxidant. Science 1984, 224, 569-573. [CrossRef]

263. Alkam, T.; Nitta, A.; Mizoguchi, H.; Itoh, A.; Nabeshima, T. A natural scavenger of peroxynitrites, rosmarinic acid, protects against impairment of memory induced by Abeta(25-35). Behav. Brain Res. 2007, 180, 139-145. [CrossRef] 
264. Iuvone, T.; De Filippis, D.; Esposito, G.; D'Amico, A.; Izzo, A.A. The spice sage and its active ingredient rosmarinic acid protect PC12 cells from amyloid-beta peptide-induced neurotoxicity. J. Pharmacol. Exp. Ther. 2006, 317, 1143-1149. [CrossRef]

265. Cornejo, A.; Aguilar Sandoval, F.; Caballero, L.; Machuca, L.; Muñoz, P.; Caballero, J.; Perry, G.; Ardiles, A.; Areche, C.; Melo, F. Rosmarinic acid prevents fibrillization and diminishes vibrational modes associated to $\beta$ sheet in tau protein linked to Alzheimer's disease. J. Enzym. Inhib. Med. Chem. 2017, 32, 945-953. [CrossRef]

266. Siddique, Y.H.; Ali, F. Protective effect of nordihydroguaiaretic acid (NDGA) on the transgenic Drosophila model of Alzheimer's disease. Chem. Biol. Interact. 2017, 269, 59-66. [CrossRef]

267. Ono, K.; Hasegawa, K.; Yoshiike, Y.; Takashima, A.; Yamada, M.; Naiki, H. Nordihydroguaiaretic acid potently breaks down pre-formed Alzheimer's beta-amyloid fibrils in vitro. J. Neurochem. 2002, 81, 434-440. [CrossRef]

268. Dong, X.; Zhang, D.; Zhang, L.; Li, W.; Meng, X. Osthole improves synaptic plasticity in the hippocampus and cognitive function of Alzheimer's disease rats via regulating glutamate. Neural Regen Res. 2012, 7, 2325-2332.

269. Jiao, Y.; Kong, L.; Yao, Y.; Li, S.; Tao, Z.; Yan, Y.; Yang, J. Osthole decreases beta amyloid levels through up-regulation of miR-107 in Alzheimer's disease. Neuropharmacology 2016, 108, 332-344. [CrossRef]

270. Yao, Y.; Wang, Y.; Kong, L.; Chen, Y.; Yang, J. Osthole decreases tau protein phosphorylation via PI3K/AKT/GSK-3 $\beta$ signaling pathway in Alzheimer's disease. Life Sci. 2019, 217, 16-24. [CrossRef]

271. Kwak, H.M.; Jeon, S.Y.; Sohng, B.H.; Kim, J.G.; Lee, J.M.; Lee, K.B.; Jeong, H.H.; Hur, J.M.; Kang, Y.H.; Song, K.S. beta-Secretase (BACE1) inhibitors from pomegranate (Punica granatum) husk. Arch. Pharmacal Res. 2005, 28, 1328-1332. [CrossRef]

272. Kiasalari, Z.; Heydarifard, R.; Khalili, M.; Afshin-Majd, S.; Baluchnejadmojarad, T.; Zahedi, E.; Sanaierad, A.; Roghani, M. Ellagic acid ameliorates learning and memory deficits in a rat model of Alzheimer's disease: An exploration of underlying mechanisms. Psychopharmacology 2017. [CrossRef]

273. Chai, G.S.; Jiang, X.; Ni, Z.F.; Ma, Z.W.; Xie, A.J.; Cheng, X.S.; Wang, Q.; Wang, J.Z.; Liu, G.P. Betaine attenuates Alzheimer-like pathological changes and memory deficits induced by homocysteine. J. Neurochem. 2013, 124, 388-396. [CrossRef]

274. Liu, X.P.; Qian, X.; Xie, Y.; Qi, Y.; Peng, M.F.; Zhan, B.C.; Lou, Z.Q. Betaine suppressed Abeta generation by altering amyloid precursor protein processing. Neurol. Sci. 2014, 35, 1009-1013.

275. Peng, Y.; Hou, C.; Yang, Z.; Li, C.; Jia, L.; Liu, J.; Tang, Y.; Shi, L.; Li, Y.; Long, J.; et al. Hydroxytyrosol mildly improve cognitive function independent of APP processing in APP/PS1 mice. Mol. Nutr. Food Res. 2016, 60, 2331-2342. [CrossRef]

276. Nardiello, P.; Pantano, D.; Lapucci, A.; Stefani, M.; Casamenti, F. Diet Supplementation with Hydroxytyrosol Ameliorates Brain Pathology and Restores Cognitive Functions in a Mouse Model of Amyloid-beta Deposition. J. Alzheimers Dis. 2018, 63, 1161-1172. [CrossRef]

277. Kim, T.I.; Lee, Y.K.; Park, S.G.; Choi, I.S.; Ban, J.O.; Park, H.K.; Nam, S.Y.; Yun, Y.W.; Han, S.B.; Oh, K.W.; et al. l-Theanine, an amino acid in green tea, attenuates beta-amyloid-induced cognitive dysfunction and neurotoxicity: Reduction in oxidative damage and inactivation of ERK/p38 kinase and NF-kappaB pathways. Free Radic. Biol. Med. 2009, 47, 1601-1610. [CrossRef]

278. Ben, P.; Zhang, Z.; Zhu, Y.; Xiong, A.; Gao, Y.; Mu, J.; Yin, Z.; Luo, L. 1-Theanine attenuates cadmium-induced neurotoxicity through the inhibition of oxidative damage and tau hyperphosphorylation. NeuroToxicology 2016, 57, 95-103. [CrossRef] [PubMed]

279. Alonso, E.; Vale, C.; Vieytes, M.R.; Laferla, F.M.; Gimenez-Llort, L.; Botana, L.M. 13-Desmethyl spirolide-C is neuroprotective and reduces intracellular Abeta and hyperphosphorylated tau in vitro. Neurochem. Int. 2011, 59, 1056-1065. [CrossRef] [PubMed]

280. Alonso, E.; Otero, P.; Vale, C.; Alfonso, A.; Antelo, A.; Giménez-Llort, L.; Chabaud, L.; Guillou, C.; Botana, L.M. Benefit of 13-desmethyl spirolide $C$ treatment in triple transgenic mouse model of Alzheimer disease: Beta-amyloid and neuronal markers improvement. Curr. Alzheimer Res. 2013, 10, 279-289. [CrossRef]

281. Ferrandiz, M.L.; Alcaraz, M.J. Anti-inflammatory activity and inhibition of arachidonic acid metabolism by flavonoids. Agents Actions 1991, 32, 283-288. [CrossRef] [PubMed]

282. Thamizhiniyan, V.; Vijayaraghavan, K.; Subramanian, S.P. Gossypin, a flavonol glucoside protects pancreatic beta-cells from glucotoxicity in streptozotocin-induced experimental diabetes in rats. Biomed. Prev. Nutr. 2012, 2, 239-245. [CrossRef] 
283. Zhang, G.L.; Deng, J.P.; Wang, B.H.; Zhao, Z.W.; Li, J.; Gao, L.; Liu, B.L.; Xong, J.R.; Guo, X.D.; Yan, Z.Q.; et al. Gypenosides improve cognitive impairment induced by chronic cerebral hypoperfusion in rats by suppressing oxidative stress and astrocytic activation. Behav. Pharmacol. 2011, 22, 633-644. [CrossRef] [PubMed]

284. Fujiwara, H.; Tabuchi, M.; Yamaguchi, T.; Iwasaki, K.; Furukawa, K.; Sekiguchi, K.; Ikarashi, Y.; Kudo, Y.; Higuchi, M.; Saido, T.C.; et al. A traditional medicinal herb Paeonia suffruticosa and its active constituent 1,2,3,4,6-penta-O-galloyl-beta-D-glucopyranose have potent anti-aggregation effects on Alzheimer's amyloid beta proteins in vitro and in vivo. J. Neurochem. 2009, 109, 1648-1657. [CrossRef] [PubMed]

285. Cui, H.; King, A.E.; Jacobson, G.A.; Small, D.H. Peripheral treatment with enoxaparin exacerbates amyloid plaque pathology in Tg2576 mice. J. Neurosci. Res. 2017, 95, 992-999. [CrossRef]

286. Bergamaschini, L.; Rossi, E.; Storini, C.; Pizzimenti, S.; Distaso, M.; Perego, C.; De Luigi, A.; Vergani, C.; De Simoni, M.G. Peripheral treatment with enoxaparin, a low molecular weight heparin, reduces plaques and beta-amyloid accumulation in a mouse model of Alzheimer's disease. J. Neurosci. 2004, 24, 4181-4186. [CrossRef]

287. Timmer, N.M.; van Dijk, L.; der Zee, C.E.E.M.V.; Kiliaan, A.; de Waal, R.M.W.; Verbeek, M.M. Enoxaparin treatment administered at both early and late stages of amyloid $\beta$ deposition improves cognition of APPswe/PS1dE9 mice with differential effects on brain A $\beta$ levels. Neurobiol. Dis. 2010, 40, 340-347. [CrossRef]

288. Gong, E.J.; Park, H.R.; Kim, M.E.; Piao, S.; Lee, E.; Jo, D.G.; Chung, H.Y.; Ha, N.C.; Mattson, M.P.; Lee, J. Morin attenuates tau hyperphosphorylation by inhibiting GSK3beta. Neurobiol. Dis. 2011, 44, 223-230. [CrossRef]

289. Sachdeva, A.K.; Kuhad, A.; Chopra, K. Naringin ameliorates memory deficits in experimental paradigm of Alzheimer's disease by attenuating mitochondrial dysfunction. Pharmacol. Biochem. Behav. 2014, 127, 101-110. [CrossRef]

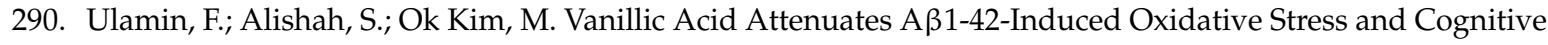
Impairment in Mice. Sci. Rep. 2017, 7, 40753.

291. Kim, Y.E.; Hwang, C.J.; Lee, H.P.; Kim, C.S.; Son, D.J.; Ham, Y.W.; Hellström, M.; Han, S.B.; Kim, H.S.; Park, E.K.; et al. Inhibitory effect of punicalagin on lipopolysaccharide-induced neuroinflammation, oxidative stress and memory impairment via inhibition of nuclear factor-kappaB. Neuropharmacology 2017, 117, $21-32$. [CrossRef]

292. Chonpathompikunlert, P.; Wattanathorn, J.; Muchimapura, S. Piperine, the main alkaloid of Thai black pepper, protects against neurodegeneration and cognitive impairment in animal model of cognitive deficit like condition of Alzheimer's disease. Food Chem. Toxicol. 2010, 48, 798-802. [CrossRef]

293. Shrivastava, P.; Vaibhav, K.; Tabassum, R.; Khan, A.; Ishrat, T.; Khan, M.M.; Ahmad, A.; Islam, F.; Safhi, M.M.; Islam, F. Anti-apoptotic and Anti-inflammatory effect of Piperine on 6-OHDA induced Parkinson's Rat model. J. Nutr. Biochem. 2013, 24, 680-687. [CrossRef]

294. Gao, J.; Inagaki, Y.; Li, X.; Kokudo, N.; Tang, W. Research progress on natural products from traditional Chinese medicine in treatment of Alzheimer's disease. Drug Discov. Ther. 2013, 7, 46-57.

295. Jeong, J.H.; Jeong, H.R.; Jo, Y.N.; Kim, H.J.; Shin, J.H.; Heo, H.J. Ameliorating effects of aged garlic extracts against $\mathrm{A} \beta$-induced neurotoxicity and cognitive impairment. BMC Complement. Altern. Med. 2013, 13, 268. [CrossRef]

296. Gupta, V.B.; Indi, S.S.; Rao, K.S. Garlic extract exhibits antiamyloidogenic activity on amyloid-beta fibrillogenesis: Relevance to Alzheimer's disease. Phytother. Res. PTR 2009, 23, 111-115. [CrossRef]

297. Nillert, N.; Pannangrong, W.; Welbat, J.U.; Chaijaroonkhanarak, W.; Sripanidkulchai, K.; Sripanidkulchai, B. Neuroprotective effects of aged garlic extract on cognitive dysfunction and neuroinflammation induced by $\beta$-amyloid in rats. Nutrients 2017, 9, 24. [CrossRef]

298. Chauhan, N.B. Effect of aged garlic extract on APP processing and tau phosphorylation in Alzheimer's transgenic model Tg2576. J. Ethnopharmacol. 2006, 108, 385-394. [CrossRef]

299. Ho, S.C.; Chang, K.S.; Chang, P.W. Inhibition of neuroinflammation by cinnamon and its main components. Food Chem. 2013, 138, 2275-2282. [CrossRef]

300. Modi, K.K.; Roy, A.; Brahmachari, S.; Rangasamy, S.B.; Pahan, K. Cinnamon and Its Metabolite Sodium Benzoate Attenuate the Activation of p21rac and Protect Memory and Learning in an Animal Model of Alzheimer's Disease. PLoS ONE 2015, 10, e0130398. [CrossRef]

301. Frydman-Marom, A.; Levin, A.; Farfara, D.; Benromano, T.; Scherzer-Attali, R.; Peled, S.; Vassar, R.; Segal, D.; Gazit, E.; Frenkel, D.; et al. Orally administrated cinnamon extract reduces beta-amyloid oligomerization and corrects cognitive impairment in Alzheimer's disease animal models. PLoS ONE 2011, 6, e16564. [CrossRef] 
302. Lauretti, E.; Iuliano, L.; Praticò, D. Extra-virgin olive oil ameliorates cognition and neuropathology of the 3xTg mice: Role of autophagy. Ann. Clin. Transl. Neurol. 2017, 4, 564-574. [CrossRef]

303. Qosa, H.; Mohamed, L.A.; Batarseh, Y.S.; Alqahtani, S.; Ibrahim, B.; LeVine, H.; Keller, J.N.; Kaddoumi, A. Extra-virgin olive oil attenuates amyloid- $\beta$ and tau pathologies in the brains of TgSwDI mice. J. Nutr. Biochem. 2015, 26, 1479-1490. [CrossRef]

304. Amel, N.; Wafa, T.; Samia, D.; Yousra, B.; Issam, C.; Cheraif, I.; Attia, N.; Mohamed, H. Extra virgin olive oil modulates brain docosahexaenoic acid level and oxidative damage caused by 2,4-Dichlorophenoxyacetic acid in rats. J. Food Sci. Technol. 2016, 53, 1454-1464. [CrossRef]

305. Chauhan, N.; Wang, K.C.; Wegiel, J.; Malik, M.N. Walnut extract inhibits the fibrillization of amyloid beta-protein, and also defibrillizes its preformed fibrils. Curr. Alzheimer Res. 2004, 1, 183-188. [CrossRef]

306. Zou, J.; Cai, P.-S.; Xiong, C.-M.; Ruan, J.-L. Neuroprotective effect of peptides extracted from walnut (Juglans Sigilata Dode) proteins on Aß25-35-induced memory impairment in mice. J. Huazhong Univ. Sci. Technol. Med. Sci. 2016, 36, 21-30. [CrossRef]

307. Balu, M.; Sangeetha, P.; Murali, G.; Panneerselvam, C. Age-related oxidative protein damages in central nervous system of rats: Modulatory role of grape seed extract. Int. J. Dev. Neurosci. 2005, 23, 501-507. [CrossRef]

308. Ono, K.; Condron, M.M.; Ho, L.; Wang, J.; Zhao, W.; Pasinetti, G.M.; Teplow, D.B. Effects of grape seed-derived polyphenols on amyloid beta-protein self-assembly and cytotoxicity. J. Biol. Chem. 2008, 283, 32176-32187. [CrossRef]

309. Wang, J.; Ho, L.; Zhao, W.; Ono, K.; Rosensweig, C.; Chen, L.; Humala, N.; Teplow, D.B.; Pasinetti, G.M. Grape-derived polyphenolics prevent Abeta oligomerization and attenuate cognitive deterioration in a mouse model of Alzheimer's disease. J. Neurosci. 2008, 28, 6388-6392. [CrossRef]

310. Wang, Y.J.; Thomas, P.; Zhong, J.H.; Bi, F.F.; Kosaraju, S.; Pollard, A.; Fenech, M.; Zhou, X.F. Consumption of grape seed extract prevents amyloid-beta deposition and attenuates inflammation in brain of an Alzheimer's disease mouse. Neurotox Res. 2009, 15, 3-14. [CrossRef]

311. Pervin, M.; Hasnat, M.A.; Lee, Y.M.; Kim, D.H.; Jo, J.E.; Lim, B.O. Antioxidant activity and acetylcholinesterase inhibition of grape skin anthocyanin (GSA). Molecules 2014, 19, 9403-9418. [CrossRef]

312. Loureiro, J.; Andrade, S.; Duarte, A.; Neves, A.; Queiroz, J.; Nunes, C.; Sevin, E.; Fenart, L.; Gosselet, F.; Coelho, M.; et al. Resveratrol and Grape Extract-loaded Solid Lipid Nanoparticles for the Treatment of Alzheimer's Disease. Molecules 2017, 22, 277. [CrossRef]

313. Hartman, R.E.; Shah, A.; Fagan, A.M.; Schwetye, K.E.; Parsadanian, M.; Schulman, R.N.; Finn, M.B.; Holtzman, D.M. Pomegranate juice decreases amyloid load and improves behavior in a mouse model of Alzheimer's disease. Neurobiol. Dis. 2006, 24, 506-515. [CrossRef]

314. Ahmed, A.H.; Subaiea, G.M.; Eid, A.; Li, L.; Seeram, N.P.; Zawia, N.H. Pomegranate extract modulates processing of amyloid-beta precursor protein in an aged Alzheimer's disease animal model. Curr. Alzheimer Res. 2014, 11, 834-843. [CrossRef]

315. Essa, M.M.; Subash, S.; Akbar, M.; Al-Adawi, S.; Guillemin, G.J. Long-term dietary supplementation of pomegranates, figs and dates alleviate neuroinflammation in a transgenic mouse model of Alzheimer's disease. PLoS ONE 2015, 10, e0120964. [CrossRef]

316. Subash, S.; Essa, M.M.; Al-Asmi, A.; Al-Adawi, S.; Vaishnav, R.; Braidy, N.; Manivasagam, T.; Guillemin, G.J. Pomegranate from Oman Alleviates the Brain Oxidative Damage in Transgenic Mouse Model of Alzheimer's disease. J. Tradit. Complement. Med. 2014, 4, 232-238. [CrossRef]

317. Jeong, K.; Shin, Y.C.; Park, S.; Park, J.S.; Kim, N.; Um, J.Y.; Go, H.; Sun, S.; Lee, S.; Park, W.; et al. Ethanol extract of Scutellaria baicalensis Georgi prevents oxidative damage and neuroinflammation and memorial impairments in artificial senescense mice. J. Biomed. Sci. 2011, 18, 14. [CrossRef]

318. Ebenezer, P.J.; Wilson, C.B.; Wilson, L.D.; Nair, A.R.; J, F. The Anti-Inflammatory Effects of Blueberries in an Animal Model of Post-Traumatic Stress Disorder (PTSD). PLoS ONE 2016, 11, e0160923. [CrossRef]

319. Ma, H.; Johnson, S.L.; Liu, W.; DaSilva, N.A.; Meschwitz, S.; Dain, J.A.; Seeram, N.P. Evaluation of Polyphenol Anthocyanin-Enriched Extracts of Blackberry, Black Raspberry, Blueberry, Cranberry, Red Raspberry, and Strawberry for Free Radical Scavenging, Reactive Carbonyl Species Trapping, Anti-Glycation, Anti-beta-Amyloid Aggregation, and Microglial Neuroprotective Effects. Int. J. Mol. Sci. 2018, 19, 461.

320. Sutalangka, C.; Wattanathorn, J.; Muchimapura, S.; Thukham-mee, W. Moringa oleifera mitigates memory impairment and neurodegeneration in animal model of age-related dementia. Oxid. Med. Cell. Longev. 2013, 2013, 695936. [CrossRef] 
321. Forloni, G.; Colombo, L.; Girola, L.; Tagliavini, F.; Salmona, M. Anti-amyloidogenic activity of tetracyclines: Studies in vitro. FEBS Lett. 2001, 487, 404-407. [CrossRef]

322. Airoldi, C.; Sironi, E.; Dias, C.; Marcelo, F.; Martins, A.; Rauter, A.P.; Nicotra, F.; Jimenez-Barbero, J. Natural compounds against Alzheimer's disease: Molecular recognition of Abeta1-42 peptide by Salvia sclareoides extract and its major component, rosmarinic acid, as investigated by NMR. Chem. Asian J. 2013, 8, 596-602. [CrossRef]

323. Fujiwara, H.; Iwasaki, K.; Furukawa, K.; Seki, T.; He, M.; Maruyama, M.; Tomita, N.; Kudo, Y.; Higuchi, M.; Saido, T.C.; et al. Uncaria rhynchophylla, a Chinese medicinal herb, has potent antiaggregation effects on Alzheimer's beta-amyloid proteins. J. Neurosci. Res. 2006, 84, 427-433. [CrossRef]

324. Luo, Q.; Lin, T.; Zhang, C.Y.; Zhu, T.; Wang, L.; Ji, Z.; Jia, B.; Ge, T.; Peng, D.; Chen, W. A novel glyceryl monoolein-bearing cubosomes for gambogenic acid: Preparation, cytotoxicity and intracellular uptake. Int. J. Pharm. 2015, 493, 30-39. [CrossRef]

325. Williams, P.; Sorribas, A.; Liang, Z. New methods to explore marine resources for Alzheimer's therapeutics. Curr. Alzheimer Res. 2010, 7, 210-213. [CrossRef]

326. Zhang, H.; Conte, M.M.; Khalil, Z.; Huang, X.-C.; Capon, R.J. New dictyodendrins as BACE inhibitors from a southern Australian marine sponge, Ianthella sp. RSC Adv. 2012, 2, 4209-4214. [CrossRef]

327. Jeon, S.Y.; Bae, K.; Seong, Y.H.; Song, K.S. Green tea catechins as a BACE1 (beta-secretase) inhibitor. Bioorg. Med. Chem. Lett. 2003, 13, 3905-3908. [CrossRef]

328. Leiros, M.; Alonso, E.; Rateb, M.E.; Houssen, W.E.; Ebel, R.; Jaspars, M.; Alfonso, A.; Botana, L.M. Gracilins: Spongionella-derived promising compounds for Alzheimer disease. Neuropharmacology 2015, 93, 285-293. [CrossRef]

329. Zhang, H.; Conte, M.M.; Huang, X.C.; Khalil, Z.; Capon, R.J. A search for BACE inhibitors reveals new biosynthetically related pyrrolidones, furanones and pyrroles from a southern Australian marine sponge, Ianthella sp. Org. Biomol. Chem. 2012, 10, 2656-2663. [CrossRef]

330. Williams, P.; Sorribas, A.; Howes, M.J. Natural products as a source of Alzheimer's drug leads. Nat. Prod. Rep. 2011, 28, 48-77. [CrossRef]

331. Liu, J.; Chen, W.; Xu, Y.; Ren, S.; Zhang, W.; Li, Y. Design, synthesis and biological evaluation of tasiamide B derivatives as BACE1 inhibitors. Bioorg. Med. Chem. 2015, 23, 1963-1974. [CrossRef]

332. Dai, J.; Sorribas, A.; Yoshida, W.Y.; Kelly, M.; Williams, P.G. Topsentinols, 24-isopropyl steroids from the marine sponge Topsentia sp. J. Nat. Prod. 2010, 73, 1597-1600. [CrossRef]

333. Dai, J.; Sorribas, A.; Yoshida, W.Y.; Kelly, M.; Williams, P.G. Xestosaprols from the Indonesian marine sponge Xestospongia sp. J. Nat. Prod. 2010, 73, 1188-1191. [CrossRef]

334. Alonso, E.; Vale, C.; Vieytes, M.R.; Botana, L.M. Translocation of PKC by yessotoxin in an in vitro model of Alzheimer's disease with improvement of tau and beta-amyloid pathology. ACS Chem. Neurosci. 2013, 4, 1062-1070. [CrossRef]

335. Alonso, E.; Fuwa, H.; Vale, C.; Suga, Y.; Goto, T.; Konno, Y.; Sasaki, M.; LaFerla, F.M.; Vieytes, M.R.; Gimenez-Llort, L.; et al. Design and synthesis of skeletal analogues of gambierol: Attenuation of amyloid-beta and tau pathology with voltage-gated potassium channel and $\mathrm{N}$-methyl-D-aspartate receptor implications. J. Am. Chem. Soc. 2012, 134, 7467-7479. [CrossRef]

336. Alonso, E.; Vale, C.; Vieytes, M.R.; Laferla, F.M.; Gimenez-Llort, L.; Botana, L.M. The cholinergic antagonist gymnodimine improves Abeta and tau neuropathology in an in vitro model of Alzheimer disease. Cell. Physiol. Biochem. Int. J. Exp. Cell. Physiol. Biochem. Pharmacol. 2011, 27, 783-794. [CrossRef]

337. Bidon-Chanal, A.; Fuertes, A.; Alonso, D.; Perez, D.I.; Martinez, A.; Luque, F.J.; Medina, M. Evidence for a new binding mode to GSK-3: Allosteric regulation by the marine compound palinurin. Eur. J. Med. Chem. 2013, 60, 479-489. [CrossRef]

338. Li, G.D.; Yan, W.H.; Xing, Y. Effects of schisandrone on Tau protein hyperphosphorylation in differentiation of neural stem cells from APP transgenic mice. J. Clin. Rehabil. Tissue Eng. Res. 2009, 13, 4490-4494.

339. Choi, B.; Kim, S.; Jang, B.G.; Kim, M.J. Piceatannol, a natural analogue of resveratrol, effectively reduces beta-amyloid levels via activation of alpha-secretase and matrix metalloproteinase-9. J. Funct. Foods 2016, 23, 124-134. [CrossRef]

340. Leiros, M.; Sanchez, J.A.; Alonso, E.; Rateb, M.E.; Houssen, W.E.; Ebel, R.; Jaspars, M.; Alfonso, A.; Botana, L.M. Spongionella secondary metabolites protect mitochondrial function in cortical neurons against oxidative stress. Mar. Drugs 2014, 12, 700-718. [CrossRef] 
341. Soininen, H.; Solomon, A.; Visser, P.J.; Hendrix, S.B.; Blennow, K.; Kivipelto, M.; Hartmann, T.; Hallikainen, I.; Hallikainen, M.; Helisalmi, S.; et al. 24-month intervention with a specific multinutrient in people with prodromal Alzheimer's disease (LipiDiDiet): A randomised, double-blind, controlled trial. Lancet Neurol. 2017, 16, 965-975. [CrossRef]

342. Ramalho, M.J.; Andrade, S.; Coelho, M.Á.N.; Loureiro, J.A.; Pereira, M.C. Biophysical interaction of temozolomide and its active metabolite with biomembrane models: The relevance of drug-membrane interaction for Glioblastoma Multiforme therapy. Eur. J. Pharm. Biopharm. 2019, 136, 156-163. [CrossRef]

343. Ramalho, M.J.; Sevin, E.; Gosselet, F.; Lima, J.; Coelho, M.A.N.; Loureiro, J.A.; Pereira, M.C. Receptor-mediated PLGA nanoparticles for glioblastoma multiforme treatment. Int. J. Pharm. 2018, 545, 84-92. [CrossRef]

344. Ramalho, M.J.; Pereira, M.C. Preparation and Characterization of Polymeric Nanoparticles: An Interdisciplinary Experiment. J. Chem. Educ. 2016, 93, 1446-1451. [CrossRef]

345. Jia, T.; Sun, Z.; Lu, Y.; Gao, J.; Zou, H.; Xie, F.; Zhang, G.; Xu, H.; Sun, D.; Yu, Y.; et al. A dual brain-targeting curcumin-loaded polymersomes ameliorated cognitive dysfunction in intrahippocampal amyloid-beta1-42-injected mice. Int. J. Nanomed. 2016, 11, 3765-3775.

346. Djiokeng Paka, G.; Doggui, S.; Zaghmi, A.; Safar, R.; Dao, L.; Reisch, A.; Klymchenko, A.; Roullin, V.G.; Joubert, O.; Ramassamy, C. Neuronal Uptake and Neuroprotective Properties of Curcumin-Loaded Nanoparticles on SK-N-SH Cell Line: Role of Poly(lactide-co-glycolide) Polymeric Matrix Composition. Mol. Pharm. 2016, 13, 391-403. [CrossRef]

347. Mourtas, S.; Lazar, A.N.; Markoutsa, E.; Duyckaerts, C.; Antimisiaris, S.G. Multifunctional nanoliposomes with curcumin-lipid derivative and brain targeting functionality with potential applications for Alzheimer disease. Eur. J. Med. Chem. 2014, 80, 175-183. [CrossRef]

348. Hoppe, J.B.; Coradini, K.; Frozza, R.L.; Oliveira, C.M.; Meneghetti, A.B.; Bernardi, A.; Pires, E.S.; Beck, R.C.R.; Salbego, C.G. Free and nanoencapsulated curcumin suppress $\beta$-amyloid-induced cognitive impairments in rats: Involvement of BDNF and Akt/GSK-3 $\beta$ signaling pathway. Neurobiol. Learn. Mem. 2013, 106, 134-144. [CrossRef]

349. Zhang, J.; Zhou, X.; Yu, Q.; Yang, L.; Sun, D.; Zhou, Y.; Liu, J. Epigallocatechin-3-gallate (EGCG)-Stabilized Selenium Nanoparticles Coated with Tet-1 Peptide To Reduce Amyloid- $\beta$ Aggregation and Cytotoxicity. ACS Appl. Mater. Interfaces 2014, 6, 8475-8487. [CrossRef]

350. Debnath, K.; Shekhar, S.; Kumar, V.; Jana, N.R.; Jana, N.R. Efficient Inhibition of Protein Aggregation, Disintegration of Aggregates, and Lowering of Cytotoxicity by Green Tea Polyphenol-Based Self-Assembled Polymer Nanoparticles. ACS Appl. Mater. Interfaces 2016, 8, 20309-20318. [CrossRef]

351. Meng, Q.; Wang, A.; Hua, H.; Jiang, Y.; Wang, Y.; Mu, H.; Wu, Z.; Sun, K. Intranasal delivery of Huperzine A to the brain using lactoferrin-conjugated $N$-trimethylated chitosan surface-modified PLGA nanoparticles for treatment of Alzheimer's disease. Int. J. Nanomed. 2018, 13, 705-718. [CrossRef]

352. Elnaggar, Y.S.; Etman, S.M.; Abdelmonsif, D.A.; Abdallah, O.Y. Novel piperine-loaded Tween-integrated monoolein cubosomes as brain-targeted oral nanomedicine in Alzheimer's disease: Pharmaceutical, biological, and toxicological studies. Int. J. Nanomed. 2015, 10, 5459-5473. [CrossRef]

353. Kuo, Y.-C.; Tsao, C.-W. Neuroprotection against apoptosis of SK-N-MC cells using RMP-7- and lactoferrin-grafted liposomes carrying quercetin. Int. J. Nanomed. 2017, 12, 2857-2869. [CrossRef]

(C) 2019 by the authors. Licensee MDPI, Basel, Switzerland. This article is an open access article distributed under the terms and conditions of the Creative Commons Attribution (CC BY) license (http://creativecommons.org/licenses/by/4.0/). 